Supporting Information

\title{
Chemoselective Intramolecular Carbonyl Ylide Formation Through Electronically Differentiated Malonate Diesters
}

Mina C. Nakhla, Che-Wah Lee, John L. Wood*

Contents

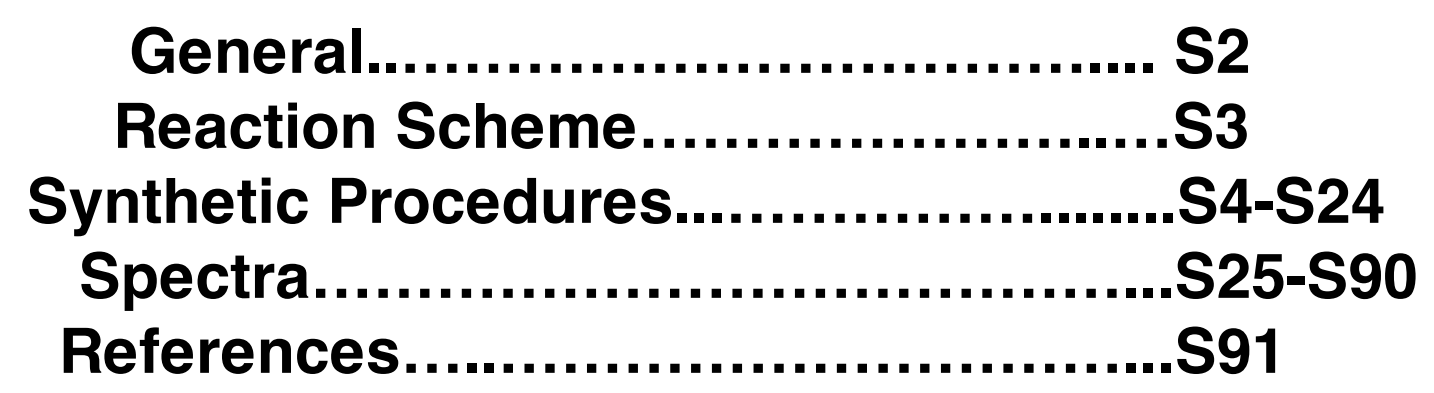




\section{Experimental Section}

\section{General:}

Unless otherwise stated, all reactions were preformed in oven-dried glassware under a nitrogen atmosphere, using reagents as received from the manufacturers. All names given throughout the supporting information were generated using the ChemBioDraw ${ }^{\circledR} 14.0$ structure to name function. The reactions were monitored by thin-layer chromatography (TLC) using Silicycle glass-backed extra hard layer, $60 \AA$ plates (indicator F-254, $250 \mu \mathrm{m}$ ). Tetrahydrofuran, dichloromethane and benzene were dried using a solvent purification system manufactured by SG Water U.S.A., LLC. Manual flash chromatography was preformed using the indicated solvent systems with Silicycle SiliaFlash ${ }^{\circledR}$ P60 (230-400 mesh) silica gel as the stationary phase. Flash Chromatography on a Teledyne RF+UV-Vis Ms Comp MPLC was preformed using the indicated solvent systems, and Teledyne RediSep ${ }^{\circledR} \mathrm{Rf}$ normal phase disposable columns of the indicated size and at the indicated flow rate. ${ }^{1} \mathrm{H}$ and ${ }^{13} \mathrm{C}$ NMR spectra were recorded on a Bruker Ascend ${ }^{\mathrm{TM}} 400$ autosampler or Bruker Ascend ${ }^{\mathrm{TM}} 600$ autosampler. Chemical shifts $(\delta)$ are reported in parts per million (ppm) relative to the residual solvent resonance and coupling constants $(\mathrm{J})$ are reported in hertz $(\mathrm{Hz})$. IR spectra were recorded on Bruker Platinum-ATR IR spectrometer using a diamond window. High Resolution mass spectra (HRMS) were obtained in the Baylor University Mass Spectrometry Center on a Thermo Scientific LTQ Orbitrap Discovery spectrometer using +ESI and reported for the molecular ion $\left(\mathrm{M}+\mathrm{H} \& \mathrm{M}+\mathrm{Na}^{+}\right)$Single crystal X-ray diffraction data were collected on a Bruker Apex II-CCD detector using Mo-K $\alpha$ radiation $(\lambda=0.71073 \AA$ ). Crystals were selected under oil, mounted on micromounts then immediately placed in a cold stream of $\mathrm{N}_{2}$. Structures were solved and refined using SHELXTL ${ }^{1}$. 


\section{General Reaction Sequence}
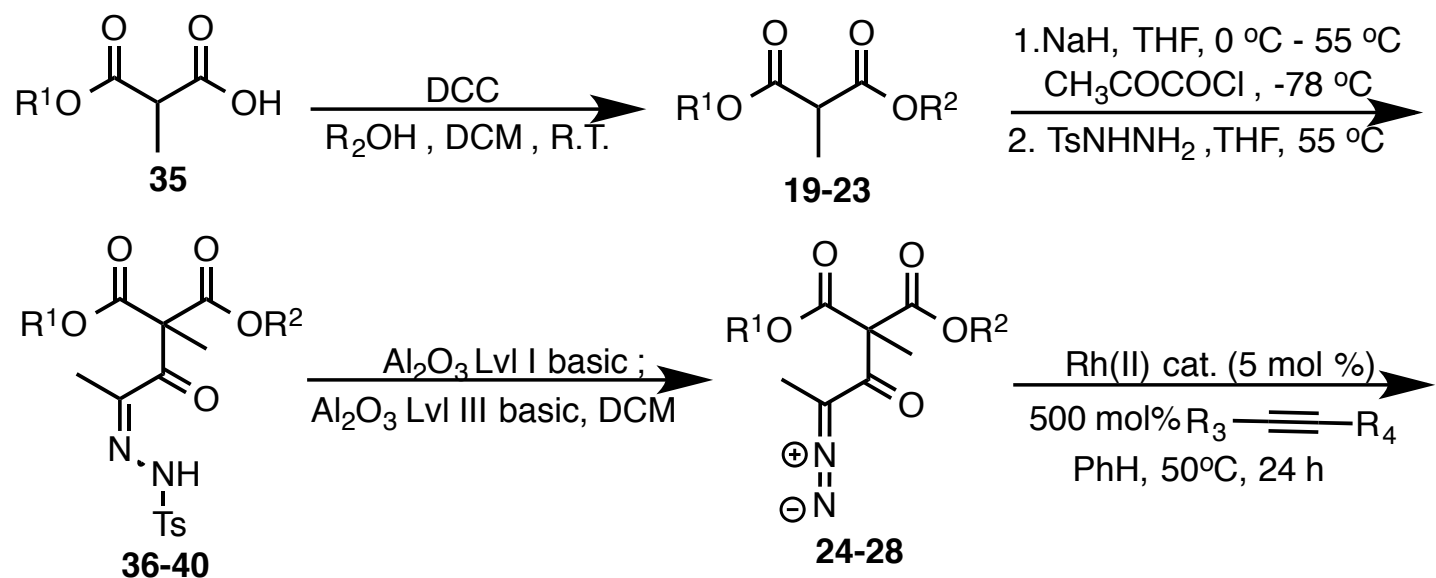

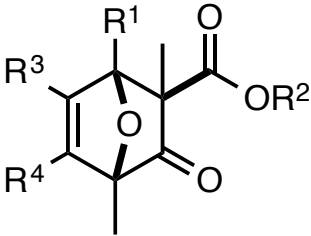

30 a-d, -32<smiles>[R2]C(=O)[C@]1(C)C(=O)OC(C)C1=O</smiles>

33-34

For synthetic procedures employed to access compounds 21, 22, bis(2,2,2-trifluoroethyl) malonate, 2-oxopropanoyl chloride and 3-ethoxy-2-methyl-3-oxopropanoic acid see references at the end of the supporting information ${ }^{2-6}$

*Note: Numbering of compounds in the supporting information does not correspond to numbering of the compounds in the manuscript. Synthetic procedures delineated in references 2-6 were slightly modified. 


\section{Synthetic Procedures for New Compounds}<smiles>CCOC(=O)C(C)C(=O)OCC(F)(F)F</smiles>

1-ethyl 3-(2,2,2-trifluoroethyl) 2-methylmalonate (compound 19) ${ }^{6}$ :

$6 \mathrm{~g}(41.06 \mathrm{mmol})$ of 3-ethoxy-2-methyl-3-oxopropanoic acid were added to a $250 \mathrm{~mL}$ round bottom flask and dissolved in $90 \mathrm{~mL}$ dry dichloromethane. Then $6.8 \mathrm{~g}$ (68 $\mathrm{mmol}, 4.95 \mathrm{~mL})$ of trifluoro ethanol and $390 \mathrm{mg}(3.2 \mathrm{mmol})$ of 4-dimethylaminopyridine were added. Following this $11.397 \mathrm{~g}(55.23 \mathrm{mmol})$ of $N, N^{\prime}$-Dicyclohexylcarbodiimide were added portion-wise to the reaction flask. The solution was left to stir for 12 hours during which $N, N^{\prime}$-Dicyclohexylurea precipitated. The mixture was filtered to remove $N, N$-Dicyclohexylurea and the filtrate extracted twice with $50 \mathrm{~mL}$ of $1 \mathrm{M} \mathrm{HCl}$ and twice more with $50 \mathrm{~mL}$ of saturated sodium bicarbonate. The organic layer was filtered again to remove any additional N, N'-Dicyclohexylurea that precipitated during the work-up. The organic layer was then dried over sodium sulfate and most of the solvent removed under reduced pressure.

The remaining organic layer was then cooled in a dry ice acetone bath to facilitate $N^{\prime} N^{\prime}$ Dicyclohexylurea precipitation and it was once again filtered. The remainder of the solvent was removed under reduced pressure and the crude product was purified by flash chromatography using silica gel and a gradient beginning at 3:97 ethyl acetate/hexanes and progressing to 1:9 ethyl acetate/hexanes. This Yielded $6.5 \mathrm{~g} \mathrm{(69 \% )}$ of the 1-ethyl 3-(2,2,2-trifluoroethyl) 2methylmalonate as a light clear oil.

${ }^{1}$ H NMR (400 MHz, Chloroform- $\left.d\right) \delta 4.56-4.47(\mathrm{~m}, 2 \mathrm{H}), 4.23-4.15(\mathrm{~m}, 2 \mathrm{H}), 3.53(\mathrm{q}, J=7.3 \mathrm{~Hz}$, $1 \mathrm{H}), 1.45(\mathrm{~d}, J=7.3 \mathrm{~Hz}, 3 \mathrm{H}), 1.25(\mathrm{t}, J=7.1 \mathrm{~Hz}, 3 \mathrm{H})$.

${ }^{13} \mathrm{C}$ NMR (101 MHz, Chloroform-d) $\delta 169.25,168.83,122.85$ (q, $J=277.3 \mathrm{~Hz}$ ), 61.91, 60.91 (q, $J$ $=36.7 \mathrm{~Hz}), 45.88,14.02,13.53$.

+ESI-HRMS $\mathrm{m} / \mathrm{z}$ : calc'd for $\left(\mathrm{M}+\mathrm{Na}^{+}\right) \mathrm{C}_{8} \mathrm{H}_{11} \mathrm{~F}_{3} \mathrm{O}_{4} \mathrm{Na}^{+}=251.05071$, found $\mathrm{C}_{8} \mathrm{H}_{11} \mathrm{O}_{4} \mathrm{~F}_{3} \mathrm{Na}^{+}=$ 251.05025

FTIR (Neat): 2988.3, 2949.0, 1766.7, 1736.3, 1457.3,1412.6, 1382.0, 1278.6, 1158.2,1084.8,

$1048.7,1021.4974 .8,863.0,839.4,632,558.3,446.0$ 


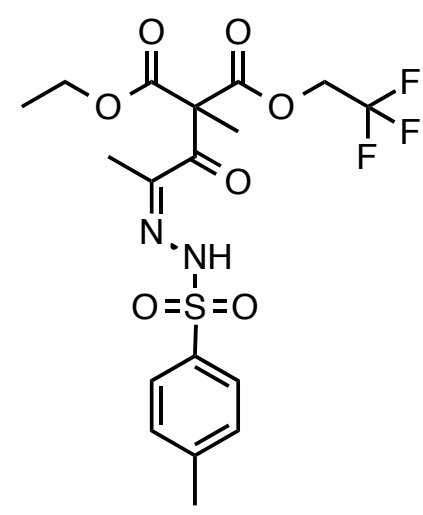

1-ethyl 3-(2,2,2-trifluoroethyl) 2-methyl-2-(2-(2tosylhydrazono)propanoyl)malonate (compound 36$)^{6}$ : To a round bottom flask was added $1.0 \mathrm{~g}(4.38 \mathrm{mmol})$ of the malonate ester 19 and $19 \mathrm{~mL}$ of dry THF. The reaction solution was then cooled in an ice water bath and let stir for ten minutes. Then $200 \mathrm{mg}(5 \mathrm{mmol})$ of sodium hydride as a $60 \%$ dispersion in mineral oil were added portion wise. After addition of the sodium hydride was complete the solution was allowed to stirred for five minutes and then heated to 55 ${ }^{\circ} \mathrm{C}$ (oil bath temperature) for one hour. After heating was complete the reaction mixture was allowed to cool to room temp, then cooled to $-78{ }^{\circ} \mathrm{C}$ using a dry ice acetone bath and allowed to stir for ten minutes at $-78{ }^{\circ} \mathrm{C}$. Following this $0.46 \mathrm{~mL}(6.05 \mathrm{mmol})$ of pyruvoyl chloride were added. Upon addition of the acyl chloride the solution turned bright yellow and thickened. The reaction mixture was allowed to stir for an additional twenty minutes at $-78{ }^{\circ} \mathrm{C}$ and then slowly allowed to warm up to room temperature over twenty minutes. It was then quenched with $5 \mathrm{~mL} 1 \mathrm{M} \mathrm{HCl}$ and $30 \mathrm{~mL}$ diethyl ether were added. The organic layer was washed twice with $25 \mathrm{~mL}$ water, and the aq. layers were combined and extracted with $25 \mathrm{~mL}$ diethyl ether. The organic layers were then combined and washed twice with $25 \mathrm{~mL}$ brine and dried over 90:10 sodium and magnesium sulfate mixture. The solvent was then evaporated under reduced pressure to give a clear yellow oil that was re-dissolved in an additional $19 \mathrm{~mL}$ of dry THF. To this solution $0.819 \mathrm{~g}(4.4 \mathrm{mmol})$ tosyl hydrazide were added at R.T. The solution was then heated for 15 hours at $55{ }^{\circ} \mathrm{C}$ (oil bath temperature), cooled to room temperature and allowed to stir for an additional hour. The solvent was evaporated under reduced pressure. Flash chromatography was preformed using an MPLC and a solvent gradient beginning at 0\% EtOAc : hexanes and progressing to 35\% EtOAc : hexanes. A 40 gram column with the flow rate set at $25 \mathrm{~mL} / \mathrm{min}$ was used.

The reaction yielded $1.023 \mathrm{~g}(50 \%)$ of the tosyl hydrazone product. An analytically pure sample was obtained by taking the purest fraction from the column.

${ }^{1}$ H NMR (400 MHz, DMSO-d 6 ) $\delta 11.88(\mathrm{br} \mathrm{s}, 1 \mathrm{H}), \delta 7.78(\mathrm{~d}, J=8.3 \mathrm{~Hz}, 2 \mathrm{H}), 7.48(\mathrm{~d}, J=8.1 \mathrm{~Hz}, 2 \mathrm{H})$, $4.78-4.66(\mathrm{~m}, 1 \mathrm{H}), 4.63-4.50(\mathrm{~m}, 1 \mathrm{H}), 4.09-3.94(\mathrm{~m}, 2 \mathrm{H}), 2.43(\mathrm{~s}, 3 \mathrm{H}), 1.93(\mathrm{~s}, 3 \mathrm{H}), 1.53(\mathrm{~s}$, $3 \mathrm{H}), 1.07$ (t, $J=7.1 \mathrm{~Hz}, 3 \mathrm{H})$.

${ }^{13} \mathrm{C}$ NMR $\left(151 \mathrm{MHz}\right.$, DMSO-d $\left.\mathbf{d}_{6}\right) \delta 190.71,166.74,166.34,146.35,144.27,135.53,129.77,127.60$, 123.13 (q, $J=277.3 \mathrm{~Hz}$ ), 63.25, 61.73, 60.78 (q, $J=35.4 \mathrm{~Hz}$ ), 21.04, 19.80, 13.49, 10.88 +ESI-HRMS $\mathrm{m} / \mathrm{z}$ : calc'd for $\left(\mathrm{M}+\mathrm{Na}^{+}\right) \mathrm{C}_{18} \mathrm{H}_{21} \mathrm{~F}_{3} \mathrm{~N}_{2} \mathrm{O}_{7} \mathrm{SNa}^{+}=489.09193$, found $\mathrm{C}_{18} \mathrm{H}_{21} \mathrm{O}_{7} \mathrm{~N}_{2} \mathrm{~F}_{3} \mathrm{NaS}^{+}=$ 489.0917

FTIR (Neat): 3215.6, 2982.1, 1765.8, 1739.7, 1696.7, 1598.7, 1450.4, 1411.0, 1352.1, 1285.1, 1255.2, 1167.8, 1114.2, 1086.6, 1036.1, 1019.6,974.1, 885.5, 714.5, 660.9, 547.1, 461.1 


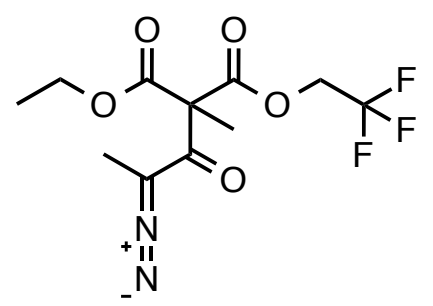

1-ethyl 3-(2,2,2-trifluoroethyl) 2-(2-diazopropanoyl)-2methylmalonate (compound 24) ${ }^{6}: 1.02 \mathrm{~g}$ of the tosyl hydrazone 36 (2.19 mmol) were added to a $50 \mathrm{~mL}$ round bottom flask and dissolved in $22.5 \mathrm{~mL}$ dry Dichloromethane. Then $2.81 \mathrm{~g}(27.5 \mathrm{mmol})$ of $\mathrm{Al}_{2} \mathrm{O}_{3}$ Brockmann LVL I were added, the flask was wrapped in foil and the reaction mixture was allowed to stir for 18.5 hours. The mixture slowly became yellow in color. Following this, $2.81 \mathrm{~g}(27.5 \mathrm{mmol})$ of $\mathrm{Al}_{2} \mathrm{O}_{3}$ Brockmann LVL III were added and the mixture stirred for an additional three hours after which the reaction mixture was poured directly into a fritted filter filled with $41.7 \mathrm{~g}$ of Brockmann LVL III $\mathrm{Al}_{2} \mathrm{O}_{3}$ and the compound eluted using dichloromethane. Analytically pure material was obtained by flash chromatography through silica gel using a gradient beginning at $0 \%$ EtOAc : hexanes progressing to $10 \%$ EtOAc : hexanes. This yielded $338.8 \mathrm{mg}$ (52\% yield) of the desired diazo compound as a bright yellow oil.

1'H NMR (400 MHz, Chloroform-d) $\delta 4.62$ (dq, $J=12.6,8.3 \mathrm{~Hz}, 1 \mathrm{H}$ ), 4.51 (dq, $J=12.6,8.3 \mathrm{~Hz}$, 1H), 4.27 (q, J=7.1 Hz, 2H), $2.02(\mathrm{~s}, 3 \mathrm{H}), 1.74(\mathrm{~s}, 3 \mathrm{H}), 1.29$ (t, $J=7.1 \mathrm{~Hz}, 3 \mathrm{H})$.

${ }^{13}$ C NMR (101 MHz, Chloroform-d) $\delta 167.51,166.71,122.66$ (q, $J=277.3 \mathrm{~Hz}$ ), 65.02, 63.07, $61.58(q, J=37.1 \mathrm{~Hz}), 18.98,13.87,9.90$.

+ESI-HRMS $\mathrm{m} / \mathrm{z}$ : calc'd for $\left(\mathrm{M}+\mathrm{Na}^{+}\right) \quad \mathrm{C}_{11} \mathrm{H}_{13} \mathrm{~F}_{3} \mathrm{~N}_{2} \mathrm{O}_{5} \mathrm{Na}^{+}=333.06743$, found $\mathrm{C}_{11} \mathrm{H}_{13} \mathrm{~F}_{3} \mathrm{~N}_{2} \mathrm{O}_{5} \mathrm{Na}^{+}=$ 333.06766

FTIR (Neat): 2986.1, 2948.5, 2077.1, 1736.0, 1621.1, 1449.2, 1411.9, 1379.6, 1330.7, 1284.0, $1246.8,1164.4,1105.3,1017.7,975.2,862.4,648.6$ 
<smiles>CCOC12OC(C)(C=C1C(=O)OC)C(=O)[C@]2(C)C(=O)OCC(F)(F)F</smiles>

2-methyl 6-(2,2,2-trifluoroethyl) 1-ethoxy-4,6-dimethyl-5-oxo7-oxabicyclo[2.2.1]hept-2-ene-2,6-dicarboxylate (compound

30a): To an oven dried 1.5 dram vial was added a stir bar and $50.9 \mathrm{mg}(0.164 \mathrm{mmol})$ of the diazo malonate $24,1.5 \mathrm{~mL}$ of dry benzene and $0.075 \mathrm{~mL}(0.843 \mathrm{mmol})$ of methyl propiolate. The reaction vial was then evacuated of air and refilled with nitrogen 3 times. $3.5 \mathrm{mg}(5 \mathrm{~mol} \%)$ of rhodium acetate dimer was then added to the reaction vial and the vial purged with a stream of nitrogen. The reaction mixture was stirred for 10 minutes at R.T. then placed in an aluminum heating block set to $50{ }^{\circ} \mathrm{C}$ for 24 hours. After 24 hours the reaction mixture was filtered through Celite ${ }^{\circledR}$ to remove the rhodium catalyst and the Celite ${ }^{\circledR}$ washed with benzene. The solvent was then evaporated under reduced pressure and the crude reaction mixture purified by flash chromatography using 1:4 Ethyl acetate : hexanes yielding $43.6 \mathrm{mg}(71 \%$ yield) of the desired oxabicycle as a clear viscous oil ${ }^{*}$. The sample used for the characterization spectra was obtained by preparative TLC using $0.5 \%$ ethyl acetate in toluene or from the purest fraction of the column.

${ }^{1}$ H NMR (400 MHz, Chloroform- $\left.d\right) \delta 7.12(\mathrm{~s}, 1 \mathrm{H}), 4.64-4.53(\mathrm{~m}, 1 \mathrm{H}), 4.50-4.39(\mathrm{~m}, 1 \mathrm{H}), 3.96-$ $3.87(\mathrm{~m}, 1 \mathrm{H}), 3.82(\mathrm{~s}, 3 \mathrm{H}), 3.75-3.65(\mathrm{~m}, 1 \mathrm{H}), 1.64(\mathrm{~s}, 3 \mathrm{H}), 1.37(\mathrm{~s}, 3 \mathrm{H}), 1.26(\mathrm{t}, J=7.0 \mathrm{~Hz}, 3 \mathrm{H})$. ${ }^{13} \mathrm{C}$ NMR (151 MHz, Chloroform- $\left.d\right)$ ) $\delta$ 203.37, 167.05, 162.07, 147.66, 143.72, 122.78 (q, $J=$ $277.4 \mathrm{~Hz}$ ), 113.16, 86.35, 63.16, 61.05 (q, $J=37.0 \mathrm{~Hz}$ ), 54.00, 52.47, 17.88, 15.12, 12.48 (d, $J=$ $1.9 \mathrm{~Hz})$.

+ESI-HRMS $\mathrm{m} / \mathrm{z}$ : calc'd for $\left(\mathrm{M}+\mathrm{Na}^{+}\right) \mathrm{C}_{15} \mathrm{H}_{17} \mathrm{~F}_{3} \mathrm{O}_{7} \mathrm{Na}^{+}=389.08186$, found $\mathrm{C}_{15} \mathrm{H}_{17} \mathrm{~F}_{3} \mathrm{O}_{7} \mathrm{Na}^{+}=$ 389.08215

FTIR (Neat): 2987.6, 2944.0, 1776.3,1752.2, 1725.1, 1611.9, 1439.4, 1384.9, 1333.4, $1268.5,1227.4,1156.7,1118.7,1075.41041 .4,1005.1,973.7,893.2,760.3$

*Note: this oxabicycle often co-eluted with a small amount of a known reaction by-product formed by cyclotrimerization of the alkyne, yield reported was corrected to take into account the minor impurity. 


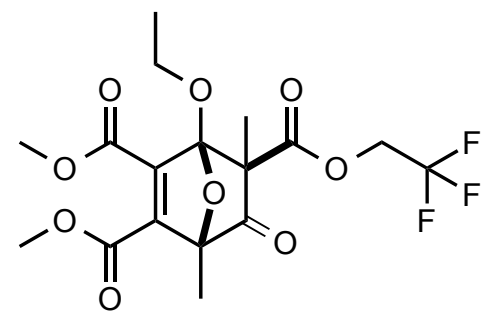

\section{2,3-dimethyl 5-(2,2,2-trifluoroethyl) 4-ethoxy-1,5-dimethyl- 6-oxo-7-oxabicyclo[2.2.1] hept-2-ene-2,3,5-tricarboxylate}

(compound 30b) : To an oven dried 1.5 dram vial was added a stir bar and $50.8 \mathrm{mg}(0.164 \mathrm{mmol})$ of the diazo malonate 24, $1.5 \mathrm{~mL}$ of dry benzene and $0.1 \mathrm{~mL}(0.813 \mathrm{mmol})$ of dimethyl acetylenedicarboxylate. The reaction vial was then evacuated of air and refilled with

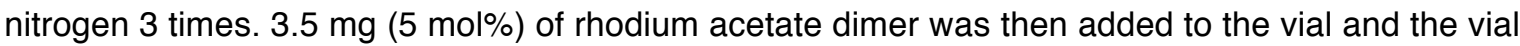
purged with a stream of nitrogen. The reaction mixture was stirred for 10 minutes at R.T. then placed in an aluminum heating block set to $50^{\circ} \mathrm{C}$ for 24 hours. After 24 hours the reaction mixture was filtered through Celite ${ }^{\circledR}$ to remove the rhodium catalyst and the Celite ${ }^{\circledR}$ washed with benzene. The solvent was then evaporated under reduced pressure and the crude reaction mixture purified by flash chromatography using a gradient beginning at 1:19 EtOAc: Hexanes progressing to 3: 22 EtOAc : hexanes yielding $56.3 \mathrm{mg}$ (80.9\% yield) of the desired oxabicycle as a clear viscous oil which crystallizes under vacuum. * An analytically pure sample and crystals for X-ray crystallographic analysis were obtained by vapor diffusion using ethyl acetate as the solvent and hexanes as the precipitant.

${ }^{1}$ H NMR (600 MHz, Chloroform-d) $\delta 4.61$ (dq, $\left.J=12.6,8.3 \mathrm{~Hz}, 1 \mathrm{H}\right), 4.42$ (dq, $J=12.6,8.3 \mathrm{~Hz}$, $1 \mathrm{H}$ ), $3.96(\mathrm{dq}, J=9.6,7.0 \mathrm{~Hz}, 1 \mathrm{H}$ ), 3.85 (s, 3H), 3.83 (s, 3H), 3.79 (dq, $J=9.4,7.0 \mathrm{~Hz}, 1 \mathrm{H}), 1.69$ (s, 3H), $1.45(\mathrm{~s}, 3 \mathrm{H}), 1.25(\mathrm{t}, J=7.0 \mathrm{~Hz}, 3 \mathrm{H})$.

${ }^{13} \mathrm{C}$ NMR (101 MHz, Chloroform-d) $\delta 201.56,166.65,161.88,161.83,145.91,145.32,122.75$ (q, $J=277.2 \mathrm{~Hz}$ ), 112.92, 86.97, 63.67, 61.17 (q, $J=37.0 \mathrm{~Hz}), 53.99,53.05,53.04,17.65,15.13$, 11.49 .

+ESI-HRMS $\mathrm{m} / \mathrm{z}$ : calc'd for $\left(\mathrm{M}+\mathrm{Na}^{+}\right) \quad \mathrm{C}_{17} \mathrm{H}_{19} \mathrm{~F}_{3} \mathrm{O}_{9} \mathrm{Na}^{+}=447.08789$, found $\mathrm{C}_{17} \mathrm{H}_{19} \mathrm{~F}_{3} \mathrm{O}_{9} \mathrm{Na}^{+}=$ 447.08765

FTIR (Neat): 2988.0, 2958.9, 1782.8, 1731.2, 1640.2, 1438.9, 1385.8,1372.1, 1329.3, 1310.9, $1275.0,1166.9,1123.9,1052.5,1030.0,1003.9,977.6$,

*Note: crystallization for the viscous oil occurs if the solvent used was ethyl acetate. Usually an oil emerges from other solvents. 
<smiles>CCCC1=C(C(=O)OC)C2(C)OC1(OCC)C(=O)C2(C)C(=O)OCC(F)(F)F</smiles>

2-methyl 6-(2,2,2-trifluoroethyl) 1-ethoxy-4,6-dimethyl-5-oxo3-propyl-7-oxabicyclo[2.2.1]hept-2-ene-2,6-dicarboxylate (compound 30d): To an oven dried 1.5 dram vial was added a stir bar and $50.1 \mathrm{mg}(0.161 \mathrm{mmol})$ of the diazo malonate $24,1.5$ $\mathrm{mL}$ of dry benzene and $.11 \mathrm{~mL}(.822 \mathrm{mmol})$ of methyl hexynoate.

The reaction vial was then evacuated of air and refilled with nitrogen 3 times. $3.5 \mathrm{mg}(5 \mathrm{~mol} \%)$ of rhodium acetate dimer was then added to the vial and the vial purged with a stream of nitrogen. The reaction mixture was stirred for 10 minutes at R.T. then placed in an aluminum heating block set to $50{ }^{\circ} \mathrm{C}$ for 24 hours. After 24 hours the reaction mixture was filtered through Celite ${ }^{\circledR}$ to remove the rhodium catalyst and the Celite ${ }^{\circledR}$ washed with benzene. The solvent was then evaporated under reduced pressure and the crude reaction mixture purified by flash chromatography with toluene as the eluent. This yielded $21 \mathrm{mg}$ (32\% yield) of the desired oxabicycle as a clear oil.

${ }^{1} \mathrm{H}$ NMR (400 MHz, Chloroform-d) $\delta 4.59$ (dq, $\left.J=12.6,8.3 \mathrm{~Hz}, 1 \mathrm{H}\right), 4.42$ (dq, $J=12.6,8.3 \mathrm{~Hz}$, 1H), $3.90-3.84(\mathrm{~m}, 1 \mathrm{H}), 3.82(\mathrm{~s}, 3 \mathrm{H}) 3.62$ (dq, $J=9.4,7.0 \mathrm{~Hz}, 1 \mathrm{H}$ ), 2.73 (ddd, $J=12.7,10.0,6.5$ $\mathrm{Hz}, 1 \mathrm{H}$ ), 2.41 (ddd, $J=12.7,9.7,5.5 \mathrm{~Hz}, 1 \mathrm{H}), 1.61(\mathrm{~s}, 3 \mathrm{H}), 1.53-1.42(\mathrm{~m}, 1 \mathrm{H}), 1.38(\mathrm{~s}, 3 \mathrm{H}), 1.36$ $-1.28(\mathrm{~m}, 1 \mathrm{H}), 1.23(\mathrm{t}, J=7.0 \mathrm{~Hz}, 3 \mathrm{H}), 0.92(\mathrm{t}, J=7.3 \mathrm{~Hz}, 3 \mathrm{H})$.

${ }^{13} \mathrm{C}$ NMR (151 MHz, Chloroform-d) $\delta 204.69,167.34,163.48,163.41,134.97,122.82$ (q, $J=$ $277.5 \mathrm{~Hz}$ ), 112.37, 88.52, 62.56, 60.99 (q, $J=36.9 \mathrm{~Hz}$ ), 54.59, 51.94, 28.62, 21.34, 18.00, 15.18, $14.44,11.05$.

+ESI-HRMS $\mathrm{m} / \mathrm{z}$ : calc'd for $\left(\mathrm{M}+\mathrm{Na}^{+}\right) \mathrm{C}_{18} \mathrm{H}_{23} \mathrm{~F}_{3} \mathrm{O}_{7} \mathrm{Na}^{+}=431.12936$, found $\mathrm{C}_{18} \mathrm{H}_{23} \mathrm{~F}_{3} \mathrm{O}_{7} \mathrm{Na}^{+}=$ 431.12906

FTIR (Neat): 2968.3,2941.3,1775.4, 1753, 1717.8, 1631.7, 1448.1, 1438, 1411, 1383.6, 1370.7, $1329.1,1285.2,1238.0,1166.9,1137.4,1120.8,1038.8,979.5$. 
<smiles>CC(C(=O)OCC(F)(F)F)C(=O)OCC(F)(F)F</smiles>

bis(2,2,2-trifluoroethyl) 2-methylmalonate (2b) : to a flame dried round bottom flask was added $283 \mathrm{mg}(1.05 \mathrm{mmol})$ of bistrifluoroethyl malonate and $10 \mathrm{~mL}$ of THF. This solution was cooled to $0{ }^{\circ} \mathrm{C}$ using an ice bath and to this was added $50 \mathrm{mg}(1.25 \mathrm{mmol})$ of $\mathrm{NaH}$ as a $60 \%$ dispersion in mineral oil. The solution was allowed to stir at $0{ }^{\circ} \mathrm{C}$ for fifteen minutes and then .072 $\mathrm{mL}(1.16 \mathrm{mmol})$ of methyl iodide were added dropwise over five minutes. The reaction was stirred for an additional fifteen minutes at $0{ }^{\circ} \mathrm{C}$ and then the ice bath removed and the reaction allowed to warm up to room temperature and stirred for hours. The reaction was then quenched with $1 \mathrm{~mL}$ ammonium chloride. Ethyl acetate was added and the reaction was washed with DI water twice. The water washes were extracted twice with ethyl acetate and the organic layers combined and washed twice with brine. The organic layer was then dried over sodium sulfate and the solvent removed under reduced pressure. The compound was then purified by flash chromatography using 1:12 EtOAc : hexanes. This yielded $162.7 \mathrm{mg}$, (55\% yield) of product as a clear oil.

${ }^{1}$ H NMR (400 MHz, Chloroform-d) $\delta 4.58-4.48$ (m, 4H), 3.67 (q, $\left.J=7.3 \mathrm{~Hz}, 1 \mathrm{H}\right), 1.52$ (d, $J=7.3 \mathrm{~Hz}$, $3 \mathrm{H})$

${ }^{13}$ C NMR (151 MHz, Chloroform- $\left.\boldsymbol{d}\right) \delta 122.70$ (q, $\left.J=277.2 \mathrm{~Hz}\right), 61.24(\mathrm{q}, J=37.1 \mathrm{~Hz}), 45.42,13.48$. +ESI-HRMS $\mathrm{m} / \mathrm{z}:$ calc'd for $\left(\mathrm{M}+\mathrm{Na}^{+}\right) \mathrm{C}_{8} \mathrm{H}_{8} \mathrm{~F}_{6} \mathrm{O}_{4} \mathrm{Na}^{+}=305.02245$, found $\mathrm{C}_{8} \mathrm{H}_{8} \mathrm{~F}_{6} \mathrm{O}_{4} \mathrm{Na}^{+}=305.02191$

FTIR (Neat): 2982.4, 2954.0, 1755.5, 1458.2, 1412.6, 1277.0, 1157.1, 1087.2, 973.3, 916.4, $841.5,651.5$. 


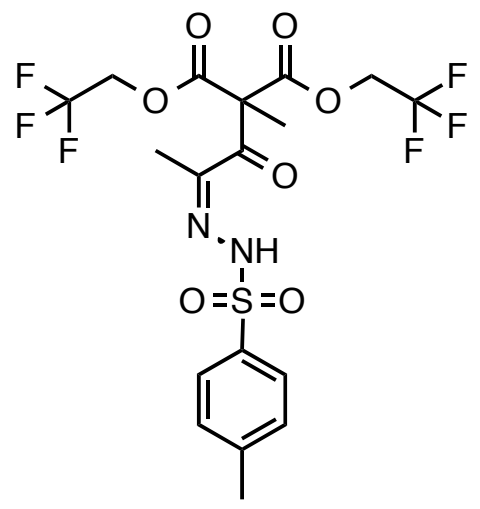

bis(2,2,2-trifluoroethyl) 2-methyl-2-(2-(2-tosylhydrazono) propanoyl)malonate (compound 37$): 500 \mathrm{mg}(1.78 \mathrm{mmol})$ of the malonate ester 20 were dissolved in $11 \mathrm{~mL}$ of dry THF. The reaction solution was then cooled in an ice water bath and let stir for ten minutes. Then $85 \mathrm{mg}(2.1 \mathrm{mmol})$ of sodium hydride as a $60 \%$ dispersion in mineral oil were added portion wise. After addition of the sodium hydride was complete the solution was allowed to stirred for five minutes and then heated to $55{ }^{\circ} \mathrm{C}$ (oil bath temperature) for one hour. After heating was complete the reaction mixture was allowed to cool to room temp, then cooled to $-78{ }^{\circ} \mathrm{C}$ using a dry ice acetone bath and allowed to stir for ten minutes at $-78{ }^{\circ} \mathrm{C}$. Following this $0.21 \mathrm{~mL}(2.76 \mathrm{mmol})$ of pyruvoyl chloride were added. Upon addition of the acyl chloride the solution turned bright yellow and thickened. The reaction mixture was allowed to stir for an additional twenty minutes at $-78{ }^{\circ} \mathrm{C}$ and then slowly allowed to warm up to room temperature over twenty minutes. It was then quenched with $3 \mathrm{~mL} 1 \mathrm{M} \mathrm{HCl}$ and $12 \mathrm{~mL}$ diethyl ether were added. The organic layer was washed twice with $12 \mathrm{~mL}$ water, and the aq. layers were combined and extracted with an additional $12 \mathrm{~mL}$ of diethyl ether. The organic layers were then combined and washed twice with $20 \mathrm{~mL}$ of brine and dried over sodium and magnesium sulfate. The solvent was then evaporated under reduced pressure to give a clear yellow oil which was re-dissolved in $11 \mathrm{~mL}$ of dry. To this solution $0.331 \mathrm{~g}(1.78 \mathrm{mmol})$ tosyl hydrazide were added at R.T. The reaction was then heated for 20 hours at $55{ }^{\circ} \mathrm{C}$ (oil bath temperatures). It was then allowed to cool to room temperature and the solvent evaporated under reduced pressure.

Flash chromatography was preformed on the crude material using an MPLC and a gradient beginning at $0 \%$ EtOAc : hexanes and progressing to 20\% EtOAc : hexanes. A 12 gram column with a flow rate of $30 \mathrm{~mL} / \mathrm{min}$ was used. This gave $343.4 \mathrm{mg} \mathrm{(37 \% )}$ of the product as a clear glassy solid. An analytically pure sample was taken from a pure fraction of the column.

${ }^{1} \mathrm{H}$ NMR (600 MHz, DMSO- $\mathbf{d}_{6}$ ) $\delta 12.05$ (br s, $\left.1 \mathrm{H}\right), 7.78$ (d, $\left.J=7.8 \mathrm{~Hz}, 2 \mathrm{H}\right), 7.49$ (d, $\left.J=7.9 \mathrm{~Hz}, 2 \mathrm{H}\right)$, $4.76-4.67(\mathrm{~m}, 2 \mathrm{H}), 4.67-4.57(\mathrm{~m}, 2 \mathrm{H}), 2.43(\mathrm{~s}, 3 \mathrm{H}), 1.93(\mathrm{~s}, 3 \mathrm{H}), 1.55(\mathrm{~s}, 3 \mathrm{H})$.

${ }^{13} \mathrm{C}$ NMR (101 MHz, DMSO- $\left.d_{6}\right) \delta$ 189.83, 165.57, 145.84, 144.32, 135.47, 129.76, 127.56, 122.95 (q, $J=277.1 \mathrm{~Hz}), 63.04,61.06$ (q, $J=35.9 \mathrm{~Hz}$ ), 20.98, 19.71, 10.75 .

+ESI-HRMS $\mathrm{m} / \mathrm{z}$ : calc'd for $\left(\mathrm{M}+\mathrm{Na}^{+}\right) \mathrm{C}_{18} \mathrm{H}_{18} \mathrm{~F}_{6} \mathrm{~N}_{2} \mathrm{O}_{7} \mathrm{SNa}^{+}=543.06366$, found $\mathrm{C}_{18} \mathrm{H}_{18} \mathrm{~F}_{6} \mathrm{~N}_{2} \mathrm{O}_{7} \mathrm{SNa}^{+}=$ 543.06580

FTIR (Neat) : 3213.6, 2923.0, 2855.0, 1775.8, 1758.4, 1699.1, 1598.5, 1452.4,1411.9, 1377.8,1352.3,1285.7,1243.9, 1168.2, 1117.5,1087.1,1036.8, 973.5, 898.9, 842.3, 816.2 713.3, $547.0,493.8$ 


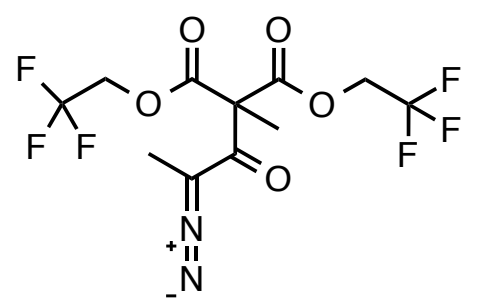

bis(2,2,2-trifluoroethyl)

2-(2-diazopropanoyl)-2-

methylmalonate (compound 25): $0.247 \mathrm{~g}$ of the tosyl hydrazone $37(0.47 \mathrm{mmol})$ were added to a $75 \mathrm{~mL}$ pear shaped flask and dissolved in $4 \mathrm{~mL}$ of dry dichloromethane. Then $0.52 \mathrm{~g}(5.1 \mathrm{mmol})$ of $\mathrm{Al}_{2} \mathrm{O}_{3}$ Brockmann LVL I were added, the flask was wrapped in foil and the reaction mixture was allowed to stir for 13 hours. The mixture slowly became yellow in color. Following this $0.52 \mathrm{~g}(5.1 \mathrm{mmol})$ of $\mathrm{Al}_{2} \mathrm{O}_{3}$ Brockmann LVL III were added and the mixture stirred for an additional 6 hours. The mixture was then poured onto a fritted filter filled with Brockmann LVL III $\mathrm{Al}_{2} \mathrm{O}_{3}$ and eluted using dichloromethane. The material was purified by flash chromatography through silica gel using a 5\% EtOAc : hexanes. This yielded $86.5 \mathrm{mg}$ (50\% yield) of the desired diazo compound as a bright yellow oil.

${ }^{1} \mathrm{H}$ NMR (400 MHz, Chloroform-d) $\delta 4.68-4.48(\mathrm{~m}, 4 \mathrm{H}), 2.03(\mathrm{~s}, 3 \mathrm{H}), 1.80(\mathrm{~s}, 3 \mathrm{H})$.

${ }^{13} \mathrm{C}$ NMR (101 MHz, Chloroform- $d$ ) $\delta 166.04,122.51$ (q, $J=277.3 \mathrm{~Hz}$ ), 64.85, 61.87 (q, $J=37.4$ $\mathrm{Hz}), 18.79,9.80$.

+ESI-HRMS $\mathrm{m} / \mathrm{z}$ : calcd for $(\mathrm{M}+\mathrm{H}): \mathrm{C}_{11} \mathrm{H}_{11} \mathrm{~F}_{6} \mathrm{~N}_{2} \mathrm{O}_{5}{ }^{+}=365.05722$, found $\mathrm{C}_{11} \mathrm{H}_{11} \mathrm{~F}_{6} \mathrm{~N}_{2} \mathrm{O}_{5}{ }^{+}=365.05679$ FTIR (Neat): 2080.3, 1756.2, 1626.2, 1451.8,1412.3, 1284.6, 1239.9, 1168.6, 1110.9, 1024.9,

976.8651 .9 
<smiles>COC(=O)C1=C(C(=O)OC)C2(C)OC1(OCC(F)(F)F)C(=O)C2(C)C(=O)OCC(F)(F)F</smiles>

2,3-dimethyl 5-(2,2,2-trifluoroethyl) 1,5-dimethyl-6-oxo-4(2,2,2-trifluoroethoxy)-7-oxabicyclo[2.2.1] hept-2-ene-2,3,5tricarboxylate (compound 31): To an oven dried 1.5 dram vial was added a stir bar and $59.4 \mathrm{mg}(0.162 \mathrm{mmol})$ of the diazo malonate $25,1.5 \mathrm{~mL}$ of dry benzene and $.1 \mathrm{~mL}(0.813$ $\mathrm{mmol}$ ) of dimethyl acetylenedicarboxylate. The reaction vial was then evacuated of air and refilled with nitrogen 3 times and then $3.5 \mathrm{mg}$ ( $5 \mathrm{~mol} \%$ ) of rhodium acetate dimer was added to the vial and the vial purged with a stream of nitrogen. The reaction mixture was stirred for 10 minutes at R.T. then placed in an aluminum heating block set to $50{ }^{\circ} \mathrm{C}$ for 24 hours. After 24 hours the reaction mixture was filtered through Celite ${ }^{\circledR}$ to remove the rhodium catalyst and the Celite ${ }^{\circledR}$ washed with benzene. The solvent was then evaporated under reduced pressure and the crude reaction mixture purified by flash chromatography using a gradient beginning at 5:95 EtOAc : hexanes progressing to 15:85 EtOAc : hexanes. This yielded $45.3 \mathrm{mg}(58 \%)$ of the product as a clear viscous oil that quickly crystalizes. An analytically pure sample and crystals for X-ray crystallographic analysis were obtain by vapor diffusion using dichloromethane as the solvent and pentane as the precipitant.

${ }^{1}$ H NMR (400 MHz, Chloroform-d) $\delta 4.57$ (dq, $J=12.6,8.2 \mathrm{~Hz}, 1 \mathrm{H}$ ), 4.41 (dq, $J=12.6,8.2 \mathrm{~Hz}$, $1 \mathrm{H}), 4.33-4.17(\mathrm{~m}, 2 \mathrm{H}), 3.87(\mathrm{~s}, 3 \mathrm{H}), 3.86(\mathrm{~s}, 3 \mathrm{H}), 1.72(\mathrm{~s}, 3 \mathrm{H}), 1.48(\mathrm{~s}, 3 \mathrm{H})$.

${ }^{13} \mathrm{C}$ NMR (101 MHz, Chloroform-d) $\delta 199.78,165.79,161.40,161.10,146.52,143.72,122.88$ (q, $J=277.0 \mathrm{~Hz}$ ), 122.65 (q, $J=277.2 \mathrm{~Hz}$ ), 111.86, 87.86, 63.96 (q, $J=36.7 \mathrm{~Hz}), 61.51$ (q, $J=37.1$ $\mathrm{Hz}), 53.70,53.32,53.23,17.46,11.32$.

+ESI-HRMS $\mathrm{m} / \mathrm{z}$ : calc'd for $\left(\mathrm{M}+\mathrm{Na}^{+}\right) \quad \mathrm{C}_{17} \mathrm{H}_{16} \mathrm{~F}_{6} \mathrm{ONa}^{+}=501.05962$, found $\mathrm{C}_{17} \mathrm{H}_{16} \mathrm{~F}_{6} \mathrm{ONa}^{+}=$ 501.05957

FTIR (Neat): 2962.3, 1786.1, 1728.7, 1640.1,1438.7, 1387.8, 1281.9, 1245.2, 1157.4, $1125.4,1073.8,1031.6,1004.3,978.2,838.6802 .4,786.6,711.9$ 


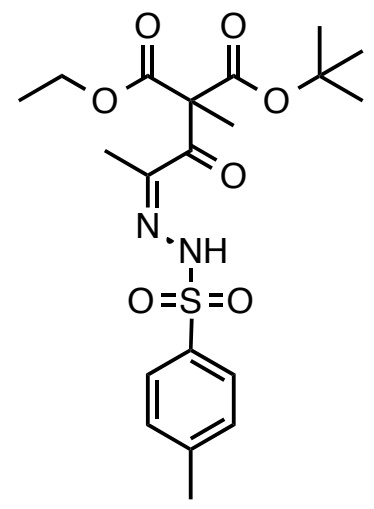

1-(tert-butyl) 3-ethyl 2-methyl-2-(2-(2-tosylhydrazono)propanoyl)

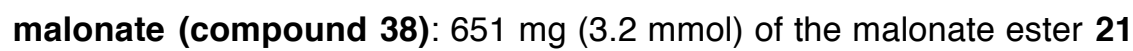
were dissolved in $13 \mathrm{~mL}$ of dry THF. The reaction solution was then cooled in an ice water bath and let stir for ten minutes. Then $151 \mathrm{mg} \mathrm{(3.8}$ $\mathrm{mmol}$ ) of sodium hydride as a $60 \%$ dispersion in mineral oil were added portion wise. After addition of the sodium hydride was complete the solution was allowed to stirred for five minutes, warmed to room temperature and then heated to $55{ }^{\circ} \mathrm{C}$ (oil bath temperature) for one hour. After heating was complete the reaction mixture was allowed to cool to room temp, then it was cooled to $-78{ }^{\circ} \mathrm{C}$ using a dry ice acetone bath and allowed to stir for at $-78{ }^{\circ} \mathrm{C}$ for ten minutes. After which $.34 \mathrm{~mL}(4.4 \mathrm{mmol})$ of pyruvoyl chloride were added. Upon addition of the acyl chloride the solution turned bright yellow and thickened. The reaction mixture was allowed to stir for an additional twenty minutes at $-78{ }^{\circ} \mathrm{C}$ and then slowly allowed to warm up to room temperature over ten minutes. It was then quenched with $5 \mathrm{~mL}$ water and $25 \mathrm{~mL}$ diethyl ether were added. The organic layer was washed twice with $5 \mathrm{~mL}$ water, and the aq. layers were combined and extracted with $25 \mathrm{~mL}$ diethyl ether. The organic layers were then combined and washed twice with $25 \mathrm{~mL}$ of brine and dried over sodium and magnesium sulfate. The solvent was then evaporated to give a clear yellow oil which was re-dissolved in $13 \mathrm{~mL}$ dry THF. To this solution $.605 \mathrm{~g}(3.26 \mathrm{mmol})$ tosyl hydrazide were added at R.T. The reaction was then heated for 18 hours at $55{ }^{\circ} \mathrm{C}$ (oil bath temperature). The solution was allowed to cool to room temperature and the solvent evaporated under reduced pressure. Flash chromatography was preformed on the crude material using an MPLC and a gradient beginning at 0\% EtOAc : hexanes and progressing to $20 \%$ EtOAc : hexanes. A 24 gram column with a flow rate of $35 \mathrm{~mL} / \mathrm{min}$ was used. This gave $547.8 \mathrm{mg}(39 \%)$ of the product as a clear glassy solid. An analytically pure sample was taken from a pure fraction of the column.

${ }^{1}$ H NMR (400 MHz, Chloroform-d) $\delta 8.09$ (br s, 1H), $\delta 7.86(\mathrm{~d}, J=8.4 \mathrm{~Hz}, 2 \mathrm{H}), 7.35$ (d, $J=7.9 \mathrm{~Hz}$, 2H), $4.17-4.04(\mathrm{~m}, 2 \mathrm{H}), 2.43(\mathrm{~s}, 3 \mathrm{H}), 1.92(\mathrm{~s}, 3 \mathrm{H}), 1.57(\mathrm{~s}, 3 \mathrm{H}), 1.35(\mathrm{~s}, 9 \mathrm{H}), 1.15(\mathrm{t}, J=7.1 \mathrm{~Hz}$, $3 \mathrm{H})$.

${ }^{13}$ C NMR (101 MHz, Chloroform-d) $\delta 191.55,168.40,166.71,146.94,145.13,134.60,130.03$, $128.70,82.81,64.56,61.81,27.84,21.78,20.21,14.02,9.71$.

+ESI-HRMS $\mathrm{m} / \mathrm{z}$ : calc'd for $\left(\mathrm{M}+\mathrm{Na}^{+}\right) \mathrm{C}_{20} \mathrm{H}_{28} \mathrm{~N}_{2} \mathrm{O}_{7} \mathrm{SNa}^{+}=463.15149$, found $\mathrm{C}_{20} \mathrm{H}_{28} \mathrm{~N}_{2} \mathrm{O}_{7} \mathrm{SNa}^{+}=$ 463.15161

FTIR (Neat): 3217.3, 2980.7, 1749.6,1731.6, 1692.5, 1598.3, 1453.5, 1395.7, 1369.7, 1352.3, 1258.1, 1168.7, 1113.8, 1086.2, 1035.0, 883.6, 847.6, 815.8, 714.3, 662.1, 569.3547 .5 


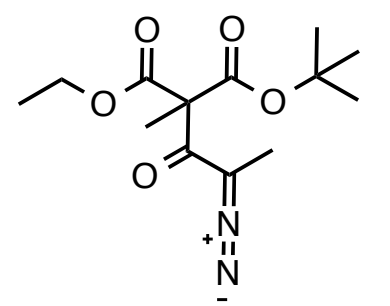

1-(tert-butyl) 3-ethyl 2-(2-diazopropanoyl)-2-methylmalonate (compound 26): 1 gram of the tosyl hydrazone $38(2.27 \mathrm{mmol})$ was added to a $75 \mathrm{~mL}$ pear shaped flask and dissolved in $4 \mathrm{~mL}$ of dry DCM. Then $2.96 \mathrm{~g}(29 \mathrm{mmol})$ of $\mathrm{Al}_{2} \mathrm{O}_{3}$ Brockmann LVL I were added, the flask was wrapped in foil and the reaction mixture was allowed to stir for 16 hours. The mixture slowly became yellow in color. Then $3.09 \mathrm{~g}(30.3 \mathrm{mmol})$ of $\mathrm{Al}_{2} \mathrm{O}_{3} \mathrm{Brockmann}$ LVL III were added and the mixture stirred for an additional hour. The mixture was then poured onto a fritted filter filled with Brockmann LVL III $\mathrm{Al}_{2} \mathrm{O}_{3}$ and eluted using dichloromethane. The material was purified by flash chromatography through silica gel using a 5\% EtOAc : hexanes. This yielded $463 \mathrm{mg}$ (63\% yield) of the desired diazo compound as a bright yellow oil.

1H NMR (400 MHz, Chloroform-d) $\delta 4.24$ (qd, $J=7.1,0.9 \mathrm{~Hz}, 2 \mathrm{H}), 2.01$ (s, 3H), 1.65 (s, 3H), 1.47 (s, 9H), 1.29 (t, $J=7.1 \mathrm{~Hz}, 3 \mathrm{H})$.

${ }^{13}$ C NMR (101 MHz, Chloroform-d) $\delta 168.48,167.04,83.48,65.98,62.38,27.83,19.14,14.06$, 9.99 .

+ESI-HRMS $\mathrm{m} / \mathrm{z}$ : calc'd for $\left(\mathrm{M}+\mathrm{Na}^{+}\right) \mathrm{C}_{13} \mathrm{H}_{20} \mathrm{~N}_{2} \mathrm{O}_{5} \mathrm{Na}^{+}=307.12699$, found $\mathrm{C}_{13} \mathrm{H}_{20} \mathrm{~N}_{2} \mathrm{O}_{5} \mathrm{Na}^{+}=$ 307.12674

FTIR (Neat): 2981.4, 2937.9, 2078.3, 1730, 1625.8, 1449.7, 1370.8, 1330.0, 1162.6, 1112.2 . $1021.1,845.0$ 


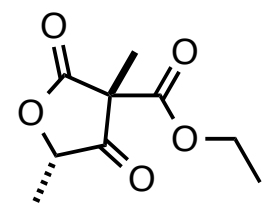

ethyl 3,5-dimethyl-2,4-dioxotetrahydrofuran-3-carboxylate (compound 33):

To an oven dried 1.5 dram vial was added a stir bar and $46.3 \mathrm{mg}(0.163 \mathrm{mmol})$ of the diazo malonate 26 , and $1.5 \mathrm{~mL}$ of dry benzene. The reaction vial was then evacuated of air and refilled with nitrogen 3 times. $3.5 \mathrm{mg}(5 \mathrm{~mol} \%)$ of rhodium acetate dimer was then added to the reaction vial and the vial purged with a stream of nitrogen. The reaction mixture was stirred for 10 minutes at R.T. then placed in an aluminum heating block set to $50{ }^{\circ} \mathrm{C}$ for 24 hours. After 24 hours the reaction mixture was filtered through Celite ${ }^{\circledR}$ to remove the rhodium catalyst and the Celite ${ }^{\circledR}$ washed with benzene. The solvent was then evaporated under reduced pressure and the crude reaction mixture purified by flash chromatography using a gradient beginning at 0\% EtOAc : hexanes and progressing to $5 \%$ EtOAc : hexanes. This yielded $18.6 \mathrm{mg}(57 \%)$ of the tetronic acid as a mix of diastereomers and as a clear oil. The Crude NMR showed that the reaction gave what appears to be a mixture of diastereomers in a 2.3:1 ratio. The major isomer was the trans isomer with respect to the methyl groups and was used for characterization. Full characterization of the minor isomer was not possible due to difficulty of purification. A crude proton NMR showing the mixture of diastereomers is included with the spectra (S64)

${ }^{1}$ H NMR (600 MHz, Chloroform- $\left.d\right) \delta 4.87$ (q, $\left.J=7.1 \mathrm{~Hz}, 1 \mathrm{H}\right), 4.29-4.19(\mathrm{~m}, 2 \mathrm{H}), 1.64(\mathrm{~d}, J=7.0$ $\mathrm{Hz}, 3 \mathrm{H}), 1.59$ (s, 3H), 1.27 (t, $J=7.1 \mathrm{~Hz}, 3 \mathrm{H})$.

${ }^{13} \mathrm{C}$ NMR (151 MHz, Chloroform-d) $\delta$ 205.82, 170.95, 163.86, 81.52, 63.53, 55.60, 17.32, 16.53, 13.98.

+ESI-HRMS $\mathrm{m} / \mathrm{z}$ : calc'd for $\left(\mathrm{M}+\mathrm{Na}^{+}\right) \mathrm{C}_{9} \mathrm{H}_{12} \mathrm{O}_{5} \mathrm{Na}^{+}=223.05824$, found $\mathrm{C}_{9} \mathrm{H}_{12} \mathrm{O}_{5} \mathrm{Na}^{+}=223.05771$ FTIR (Neat): 2990.0, 2942.7, 1807.1, 1760.1, 1450.3, 1378.1, 1330.1, 1260.9, 1219.4, 1126.4, 1099.0, 1078.8, 1013.8, 992.4 


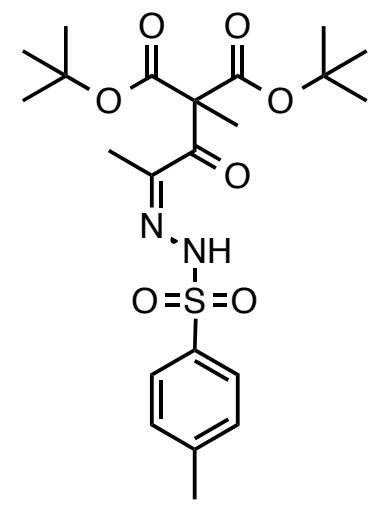

di-tert-butyl 2-methyl-2-(2-(2-tosylhydrazono)propanoyl)malonate

(compound 39): $0.503 \mathrm{~g}(2.18 \mathrm{mmol})$ of the malonate ester 22 were dissolved in $9 \mathrm{~mL}$ of dry THF. The reaction solution was then cooled in an ice water bath and let stir for ten minutes. Then $100 \mathrm{mg}(2.5 \mathrm{mmol})$ of sodium hydride as a $60 \%$ dispersion in mineral oil were added portion wise. After addition of the sodium hydride was complete the solution was allowed to warm to room temperature and then heated to $55{ }^{\circ} \mathrm{C}$ (oil bath temperature) for 80 minutes. After heating was complete the reaction mixture was allowed to cool to room temperature, then it was cooled to -

$78{ }^{\circ} \mathrm{C}$ using a dry ice acetone bath and allowed to stir for ten minutes at $-78{ }^{\circ} \mathrm{C}$. Following this 0.26 $\mathrm{mL}$ (3.4 mmol) of pyruvoyl chloride were added. Upon addition of the acyl chloride the solution turned bright yellow and thickened. The reaction mixture was allowed to stir for an additional twenty minutes at $-78{ }^{\circ} \mathrm{C}$ and then slowly allowed to warm up to room temperature and left to stir for thirty minutes. It was then quenched with $3 \mathrm{~mL}$ water and $15 \mathrm{~mL}$ diethyl ether were added. The organic layer was washed twice with $3 \mathrm{~mL}$ of water, and the aq. layers were combined and extracted with $15 \mathrm{~mL}$ diethyl ether. The organic layers were then combined, and washed with brine and dried over sodium and magnesium sulfate.

The solvent was then evaporated under reduced pressure and $9 \mathrm{~mL}$ dry THF added. To the solution was added $0.42 \mathrm{~g}(2.26 \mathrm{mmol})$ tosyl hydrazide at R.T. and the solution heated for 21.5 hours at $55{ }^{\circ} \mathrm{C}$ (oil bath temperature). It was then cooled to room temperature and the solvent removed under reduced pressure. Flash chromatography was preformed on the crude material using an MPLC and a gradient beginning at 0\% EtOAc : hexanes and progressing to $20 \%$ EtOAc : hexanes. A 24 gram column with a flow rate of $30 \mathrm{~mL} / \mathrm{min}$ was used. This gave $585 \mathrm{mg} \mathrm{(57 \% )} \mathrm{of}$ the product as a clear glassy solid and as mixture of $E$ and $Z$ isomers which were both carried on through the reaction sequence. A sample containing only the desired compounds as a mix of $E$ and $Z$ isomers was taken from the purest fraction of the column and used for characterization.

${ }^{1} \mathrm{H}$ NMR $\left(\mathbf{4 0 0} \mathrm{MHz}\right.$, Acetone- $\left.\boldsymbol{d}_{6}\right) \delta 10.11$ ( br s, 2H), 9.12 ( broad s, $\left.1 \mathrm{H}\right), \delta 7.82(\mathrm{~d}, J=8.4 \mathrm{~Hz}, 4 \mathrm{H})$, $7.76(\mathrm{~d}, J=8.3 \mathrm{~Hz}, 2 \mathrm{H}), 7.43(\mathrm{~d}, J=7.9 \mathrm{~Hz}, 4 \mathrm{H}), 7.38(\mathrm{~d}, J=7.9 \mathrm{~Hz}, 2 \mathrm{H}), 2.43(\mathrm{~s}, 6 \mathrm{H}), 2.41(\mathrm{~s}, 3 \mathrm{H})$, $1.98(\mathrm{~s}, 6 \mathrm{H}), 1.94(\mathrm{~s}, 3 \mathrm{H}), 1.49(\mathrm{~s}, 6 \mathrm{H}), 1.43(\mathrm{~s}, 3 \mathrm{H}), 1.42(\mathrm{~s}, 18 \mathrm{H}), 1.39(\mathrm{~s}, 36 \mathrm{H})$. (Integration value of Tbutyl group of major isomer set to 36 protons.)

${ }^{13}$ C NMR (151 MHz, Chloroform-d) $\delta$ 191.97, 168.71, 166.97, 153.53, 147.71, 145.20, 144.21, 135.36, 134.51, 130.07, 129.62, 128.66, 128.03, 82.55, 82.42, 65.74, 63.45, 27.88, 21.78, 21.72, $20.19,19.47,15.06,9.95$.

+ESI-HRMS $\mathrm{m} / \mathrm{z}$ : calc'd for $\left(\mathrm{M}+\mathrm{Na}^{+}\right) \quad \mathrm{C}_{22} \mathrm{H}_{32} \mathrm{~N}_{2} \mathrm{O}_{7} \mathrm{SNa}^{+}=491.18279$, found $\mathrm{C}_{22} \mathrm{H}_{32} \mathrm{~N}_{2} \mathrm{O}_{7} \mathrm{SNa}^{+}=$ 491.18369

FTIR (Neat): 3214.2, 2979.1, 2933.9, 1745.7,1727.2, 1690.2, 1598.2, 1455.3,1394.3, 1368.7, $1255.7,1165.2,1120.9,1084.7,1035.4,909.5,884.9,846.0,814.3,713.3,661.9,547$ 


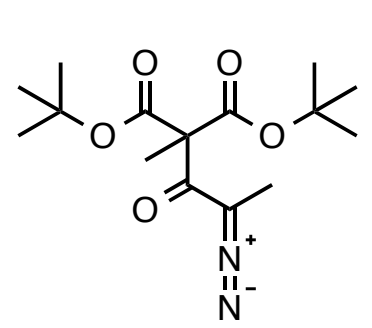

di-tert-butyl 2-(2-diazopropanoyl)-2-methylmalonate (compound 27):

$0.7 \mathrm{~g}$ of the tosyl hydrazone 39 ( $\mathrm{E}$ and $\mathrm{Z}$ mixture) $(1.5 \mathrm{mmol})$ were added to a round bottom flask and dissolved in $15 \mathrm{~mL}$ of dry DCM. Then $1.87 \mathrm{~g}$ (18.34 mmol) of $\mathrm{Al}_{2} \mathrm{O}_{3}$ Brockmann LVL I were added, the flask was wrapped in foil and the reaction mixture was allowed to stir for 14.5 hours. The mixture slowly became yellow in color. Then $1.87 \mathrm{~g} \mathrm{(18.34}$

mmol) of $\quad \mathrm{Al}_{2} \mathrm{O}_{3}$ Brockmann LVL III were added and the mixture stirred for an additional 1.5 hours. The mixture was then poured onto a fritted filter filled with Brockmann LVL III $\mathrm{Al}_{2} \mathrm{O}_{3}$ and eluted using dichloromethane. The material was purified by flash chromatography through silica gel using 10\% EtOAc : hexanes. This yielded $213.1 \mathrm{mg}$ (46\% yield) of the desired diazo compound as a bright yellow oil which upon cooling in the fridge solidified to a bright yellow solid.

${ }^{1} \mathrm{H}$ NMR (400 MHz, Chloroform-d) $\delta 2.02$ (s, 3H), 1.61 (s, 3H), 1.48 (s, 18H).

${ }^{13} \mathrm{C}$ NMR (101 MHz, Chloroform-d) $\delta$ 167.29, 83.17, 66.71, 27.91, 19.31, 10.05 .

+ESI-HRMS $\mathrm{m} / \mathrm{z}$ : calc'd for $\left(\mathrm{M}+\mathrm{Na}^{+}\right) \quad \mathrm{C}_{15} \mathrm{H}_{24} \mathrm{~N}_{2} \mathrm{O}_{5} \mathrm{Na}^{+}=335.15829$, found $\mathrm{C}_{15} \mathrm{H}_{24} \mathrm{~N}_{2} \mathrm{O}_{5} \mathrm{Na}^{+}=$ 335.15793

FTIR (Neat): I2978.4, 2925.7, 2853.9, 2078.6, 1724.0, 1622.4, 1456.5, 1393.5, 1369.2, 1328.2, $1276.8,1254.6,1160.8,1117.4,1020.3,938.6,844.9,799.2,738.2,570.5,526.9,466.7$ 


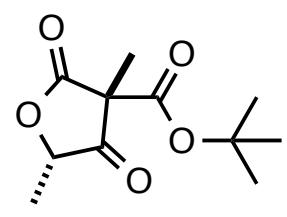

tert-butyl 3,5-dimethyl-2,4-dioxotetrahydrofuran-3-carboxylate

(compound 34): To an oven dried 1.5 dram vial was added a stir bar and $47.7 \mathrm{mg}(0.153 \mathrm{mmol})$ of the diazo malonate 27 , and $1.4 \mathrm{~mL}$ of dry benzene. The reaction vial was then evacuated of air and refilled with nitrogen 3 times. $3.5 \mathrm{mg} \mathrm{(} \sim 5 \mathrm{~mol} \%)$ of rhodium acetate dimer was then added to the reaction mixture and the vial purged with a stream of nitrogen. The reaction mixture was stirred for 10 minutes at R.T. then placed in an aluminum heating block set to $50{ }^{\circ} \mathrm{C}$ for 24 hours. After 24 hours the reaction mixture was filtered through Celite ${ }^{\circledR}$ to remove the rhodium catalyst and the Celite ${ }^{\circledR}$ washed with benzene. The solvent was then evaporated under reduced pressure and the crude reaction mixture purified by flash chromatography using a gradient beginning at 0\% EtOAc : hexanes and progressing to $5 \%$ EtOAc : hexanes. This yielded $17.8 \mathrm{mg}(51 \%)$ of the tetronic acid as a mix of diastereomers and as a clear viscous oil that slowly crystalizes. Crude NMR showed that the reaction appeared to give a mixture of diastereomers in a 5:1 ratio. The major isomer was determined by X-ray crystallographic analysis to be the trans isomer with respect to the methyl groups. An analytically pure sample and crystals for X-ray crystallographic analysis of the major diastereomer were obtained by vapor diffusion using dichloromethane as the solvent and pentane as the precipitant. Due to difficulty of purification the minor diastereomer was not fully characterized. A crude proton NMR showing the mixture of diastereomers is included with the spectra (S74).

1H NMR (400 MHz, Chloroform-d) $\delta 4.83$ (q, $J=7.0 \mathrm{~Hz}, 1 \mathrm{H}$ ), 1.63 (d, $J=7.0 \mathrm{~Hz}, 3 \mathrm{H}$ ), 1.53 (s, $3 \mathrm{H}), 1.45$ (s, 9H).

${ }^{13} \mathrm{C}$ NMR (101 MHz, Chloroform-d) $\delta$ 206.39, 171.40, 162.72, 85.15, 81.39, 56.49, 27.88, 17.28, 16.49 .

+ESI-HRMS $\mathrm{m} / \mathrm{z}$ : calc'd for $\left(\mathrm{M}+\mathrm{Na}^{+}\right) \mathrm{C}_{11} \mathrm{H}_{16} \mathrm{O}_{5} \mathrm{Na}^{+}=251.08954$, found $\mathrm{C}_{11} \mathrm{H}_{16} \mathrm{O}_{5} \mathrm{Na}^{+}=251.08911$

FTIR (Neat): 2982.6, 2940.7, 1805.9, 1758.8, 1478.4, 1450.5, 1396.4,

$1372.3,1260.4,1233.7,1153.7,1123.6,1097.7,1078.6,994.4$ 
<smiles>CCOC(=O)C(C)C(=O)OC(C)C</smiles>

1-ethyl 3-isopropyl 2-methylmalonate (compound 23) ${ }^{7}: 1.1 \mathrm{~g}(7.61$ $\mathrm{mmol}$ ) of 3-ethoxy-2-methyl-3-oxopropanoic acid were added to a round bottom flask and dissolved in $18 \mathrm{~mL}$ dry dichloromethane. To this solution was added $1 \mathrm{~mL}(13.06 \mathrm{mmol})$ of 2-propyl alcohol. Then $77.6 \mathrm{mg}(0.64 \mathrm{mmol})$ of 4 dimethylaminopyridine were added. Following this $1.65 \mathrm{~g}(8.61 \mathrm{mmol})$ of $\mathrm{N}$-(3Dimethylaminopropyl)- $N$ '-ethylcarbodiimide hydrochloride were slowly added to the reaction flask. The solution was left to stir for 11.5 hours. The crude reaction mixture was washed three times with $35 \mathrm{~mL} 1 \mathrm{~N} \mathrm{HCL}$ and the combined aqueous washes extracted once with $35 \mathrm{~mL} \mathrm{DCM}$. The combined organic layers were then washed twice with $35 \mathrm{~mL}$ saturated sodium bicarbonate, once with $70 \mathrm{~mL}$ of brine and dried over sodium sulfate. The solvent was then removed under reduced pressure. This yielded $734.5 \mathrm{mg}(51 \%)$ of the product as a clear oil. No further purification was needed.

${ }^{1}$ H NMR (400 MHz, Chloroform- $\left.d\right)$ ס 5.05 (hept, $\left.J=6.3 \mathrm{~Hz}, 1 \mathrm{H}\right), 4.25-4.13(\mathrm{~m}, 2 \mathrm{H}), 3.38$ (q, $J=$ $7.3 \mathrm{~Hz}, 1 \mathrm{H}), 1.40(\mathrm{~d}, J=7.3 \mathrm{~Hz}, 3 \mathrm{H}), 1.29-1.21(\mathrm{~m}, 9 \mathrm{H}$ overlap of a doublet and a triplet) .

${ }^{13} \mathrm{C}$ NMR (101 MHz, Chloroform-d) $\delta 170.40,169.86,68.94,61.41,46.54,21.77,21.70,14.22$, 13.62.

+ESI-HRMS $\mathrm{m} / \mathrm{z}$ : calc'd for $\left(\mathrm{M}+\mathrm{Na}^{+}\right) \quad \mathrm{C}_{9} \mathrm{H}_{16} \mathrm{O}_{4} \mathrm{Na}^{+}=211.09463$, found $\mathrm{C}_{9} \mathrm{H}_{16} \mathrm{O}_{4} \mathrm{Na}^{+}=211.09419$

FTIR (Neat): 2983.3, 1747.5, 1728.0, 1456.1, 1376.4, 1320.5, 1219.3, 1163, 1094.3, 1036.0, $935.9,902.2,866.9,828.0$ 


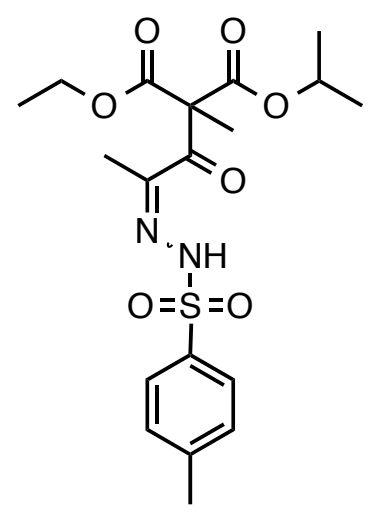

1-ethy

3-isopropyl

2-methyl-2-(2-(2-

tosylhydrazono)propanoyl)malonate (compound 40): $0.962 \mathrm{~g}$ (5.1

mmol) of the malonate ester 23 were added to a $50 \mathrm{~mL}$ round bottom flask and dissolved in $21.5 \mathrm{~mL}$ of dry THF. The reaction solution was then cooled in an ice water bath and let stir for ten minutes. Then $240 \mathrm{mg}$ $(6.0 \mathrm{mmol})$ of sodium hydride as a $60 \%$ dispersion in mineral oil were added portion wise. After addition of the sodium hydride was complete the solution was allowed to stirred for five minutes, warmed to room temperature and then heated to $55{ }^{\circ} \mathrm{C}$ (oil bath temperature) for 1.5 hours. After heating was complete the reaction mixture was allowed to cool to room temperature, it was cooled to $-78{ }^{\circ} \mathrm{C}$ using a dry ice acetone bath and allowed to stir for ten minutes at $-78{ }^{\circ} \mathrm{C}$. After which $.53 \mathrm{~mL}(7.0 \mathrm{mmol})$ of pyruvoyl chloride were added. Upon addition of the acyl chloride the solution turned bright yellow and thickened. The reaction mixture was stirred for an additional twenty minutes at $-78{ }^{\circ} \mathrm{C}$ and then slowly allowed to warm up to room temperature over thirty minutes. It was then quenched with water and $20 \mathrm{~mL}$ diethyl ether were added, and the organic layer then washed twice with water. The aq. layers were combined and extracted with diethyl ether. The organic layers were then combined and washed twice with brine and dried over sodium and magnesium sulfate. The solvent was then evaporated to give a clear yellow oil which was redissolved in $21.5 \mathrm{~mL}$ dry THF. To this solution was added $953 \mathrm{mg}(5.2 \mathrm{mmol})$ of tosyl hydrazide at R.T. and the solution heated for 16 hours at $55{ }^{\circ} \mathrm{C}$ (oil bath temperature). It was then allowed to cool to room temperature and the solvent evaporated under reduced pressure. Flash chromatography was preformed on the crude material using an MPLC and a gradient beginning at $0 \%$ EtOAc : hexanes and progressing to 35\% EtOAc : hexanes. A 24 gram column with a flow rate of $35 \mathrm{~mL} / \mathrm{min}$ was used. This gave $1.6575 \mathrm{~g}(76 \%)$ of the product as a clear glassy solid. An analytically pure sample for characterization was taken from purest fraction of the column.

${ }^{1}$ H NMR (400 MHz, Chloroform-d) $\delta 8.02$ (br s, 1H), $\delta 7.87$ (d, $\left.J=8.3 \mathrm{~Hz}, 2 \mathrm{H}\right), 7.36$ (d, $J=8.0 \mathrm{~Hz}$, $2 \mathrm{H}), 4.96(\mathrm{p}, J=6.3 \mathrm{~Hz}, 1 \mathrm{H}), 4.20-4.05(\mathrm{~m}, 2 \mathrm{H}), 2.44(\mathrm{~s}, 3 \mathrm{H}), 1.91(\mathrm{~s}, 3 \mathrm{H}), 1.61(\mathrm{~s}, 3 \mathrm{H}), 1.19-$ 1.07 ( $\mathrm{m}, 9 \mathrm{H}$ doublet and triplet overlapping).

${ }^{13} \mathrm{C}$ NMR (151 MHz, Chloroform-d) $\delta 191.31,168.17,167.42,146.47,145.13,134.55,129.99$, $128.67,69.68,63.85,62.01,21.82,21.49,21.43,20.16,13.99,9.59$.

+ESI-HRMS $\mathrm{m} / \mathrm{z}$ : calc'd for $\left(\mathrm{M}+\mathrm{Na}^{+}\right) \mathrm{C}_{19} \mathrm{H}_{26} \mathrm{~N}_{2} \mathrm{O}_{7} \mathrm{SNa}^{+}=449.13584$, found $\mathrm{C}_{19} \mathrm{H}_{26} \mathrm{~N}_{2} \mathrm{O}_{7} \mathrm{SNa}^{+}=$ 449.13519

FTIR (Neat): 3204.8, 2983.0, 1750.5, 1730.8, 1692.7, 1598.1, 1451.5, 1375.2, 1264.6, 1169.6, $1101.4,1035.3,904.0,816.3,714.5,661.9,547.1$ 


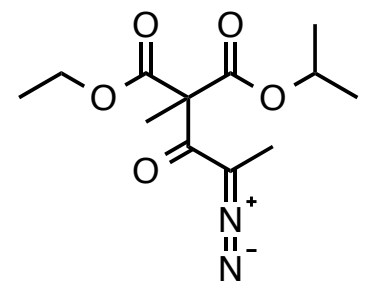

1-ethyl 3-isopropyl 2-(2-diazopropanoyl)-2-methylmalonate

(compound 28): $1.655 \mathrm{~g}$ of the tosyl hydrazone $40(3.88 \mathrm{mmol})$ were added to a pear shaped flask and dissolved in $39 \mathrm{~mL}$ of dry dichloromethane. Then $5.167 \mathrm{~g}(50.7 \mathrm{mmol})$ of $\mathrm{Al}_{2} \mathrm{O}_{3}$ Brockmann LVL I were added, the flask was wrapped in foil and the reaction mixture was allowed to stir for 13.5 hours. The mixture slowly became yellow in color. Then $5.17 \mathrm{~g}(50.7 \mathrm{mmol})$ of $\mathrm{Al}_{2} \mathrm{O}_{3}$ Brockmann LVL III were added and the mixture stirred for an additional three hours. The mixture was then poured onto a fritted filter filled with Brockmann LVL III $\mathrm{Al}_{2} \mathrm{O}_{3}$ and eluted using dichloromethane. The material was purified by flash chromatography through silica gel using 1:9 EtOAc : hexanes as the eluent. This yielded $698 \mathrm{mg}$ (67\% yield) of the desired diazo compound as a bright yellow oil.

${ }^{1}$ H NMR (400 MHz, Chloroform-d) $\delta 5.09$ (hept, 1H), 4.25 (qd, $\left.J=7.1,1.5 \mathrm{~Hz}, 2 \mathrm{H}\right), 2.02$ (s, 3H), $1.68(\mathrm{~s}, 3 \mathrm{H}), 1.32-1.22(\mathrm{~m}, 9 \mathrm{H}$ doublet and triplet overlapping).

${ }^{13} \mathrm{C}$ NMR (101 MHz, Chloroform-d) $\delta$ 168.30, 167.65, 70.41, 65.29, 62.52, 21.55, 19.08, 14.05, 10.02

+ESI-HRMS $\mathrm{m} / \mathrm{z}$ : calc'd for $\left(\mathrm{M}+\mathrm{Na}^{+}\right) \mathrm{C}_{12} \mathrm{H}_{18} \mathrm{~N}_{2} \mathrm{O}_{5} \mathrm{Na}^{+}=293.11134$, found $\mathrm{C}_{12} \mathrm{H}_{18} \mathrm{~N}_{2} \mathrm{O}_{5} \mathrm{Na}^{+}=$ 293.11096

FTIR (Neat): 2983.5, 2939.7, 2074.7, 1725.8, 1620.3, 1448.8, 1376.0, 1325.9, 1251.5, 1226.3, 1182.0, 1095.9, 1017.3. 
<smiles>CCOC12CC(C(=O)OC(C)C)(OC1(C)C(=O)C(C)=O)C(C(=O)OC)=C2C(=O)OC</smiles><smiles></smiles>

5-isopropyl 2,3-dimethyl 4-ethoxy-1,5dimethyl-6-oxo-7-oxabicyclo[2.2.1]hept2-ene-2,3,5-tricarboxylate and 5-ethyl 2, 3-dimethyl 4-isopropoxy-1,5-dimethyl-6oxo-7-oxabicyclo[2.2.1] hept-2-ene-2,3,5tricarboxylate (compounds 32/32'). To

an oven dried 1.5 dram vial was added a stir bar and $44.1 \mathrm{mg}(0.163 \mathrm{mmol})$ of the diazo malonate 28, $1.5 \mathrm{~mL}$ of dry benzene and $.1 \mathrm{~mL}(0.813 \mathrm{mmol})$ of dimethyl acetylenedicarboxylate. The reaction vial was then evacuated of air and refilled with nitrogen 3 times and then $3.5 \mathrm{mg}$ (5 mol\%) of rhodium acetate dimer was added to the reaction mixture and the vial purged with a stream of nitrogen. The reaction mixture was stirred for ten minutes at R.T. then placed in an aluminum heating block set to $50{ }^{\circ} \mathrm{C}$ for 24 hours. After 24 hours the reaction mixture was filtered through Celite ${ }^{\circledR}$ to remove the rhodium catalyst and the Celite ${ }^{\circledR}$ washed with benzene. The solvent was then evaporated under reduced pressure and the crude reaction mixture purified by flash chromatography using an MPLC. A 4 gram column set to a flow rate of $18 \mathrm{~mL} / \mathrm{min}$ with a gradient beginning at $0 \%$ EtOAc : hexanes and progressing to 5\% EtOAc : hexanes was used. This yielded $34.2 \mathrm{mg}(54 \%)$ of the product as a 2:1 mixture of isomers. The crude NMR proton showed a mixture of isomers in a 1:1 ratio.

${ }^{1} \mathrm{H}$ NMR $(600 \mathrm{MHz}$, Chloroform- $d) \delta 5.03(\mathrm{p}, J=6.3 \mathrm{~Hz}, 1 \mathrm{H}), 4.27-4.18(\mathrm{~m}, 5 \mathrm{H}), 4.17-4.09(\mathrm{~m}$, $2 \mathrm{H}), 4.00-3.93(\mathrm{~m}, 1 \mathrm{H}), 3.84(\mathrm{~s}, 7 \mathrm{H}), 3.83(\mathrm{~s}, 4 \mathrm{H}), 3.82(\mathrm{~s}, 3 \mathrm{H}), 3.81(\mathrm{~s}, 7 \mathrm{H}), 1.69(\mathrm{~s}, 6 \mathrm{H}), 1.68(\mathrm{~s}$, $3 \mathrm{H}), 1.41(\mathrm{~s}, 6 \mathrm{H}), 1.39(\mathrm{~s}, 3 \mathrm{H}), 1.27-1.19(\mathrm{~m}, 33 \mathrm{H})$. (Pentet proton of minor isomer set to an integration of 1.)

${ }^{13} \mathrm{C}$ NMR (151 MHz, Chloroform-d) $\delta$ 203.18, 202.84, 167.94, 167.43, 162.58, 162.08 (d, $J=3.7$ $\mathrm{Hz}), 161.83$, 147.62, 145.85, 145.70, 144.43, 113.52, 113.12, 86.80, 86.66, 72.09, 69.61, 63.41, $61.82,54.33,53.93,53.01,52.98,52.88,23.95,23.19,21.69,21.65,17.90,17.67,15.37,14.25$, $11.80,11.54$.

+ESI-HRMS $\mathrm{m} / \mathrm{z}$ : calc'd for $\left(\mathrm{M}+\mathrm{Na}^{+}\right) \mathrm{C}_{18} \mathrm{H}_{24} \mathrm{O}_{9} \mathrm{Na}^{+}=407.13180$, found $\mathrm{C}_{18} \mathrm{H}_{24} \mathrm{O}_{9} \mathrm{Na}^{+}=407.13235$ FTIR (Neat): 2982.8, 2956.2, 1777.8, 1729.9, 1638.3, 1437.9, 1327.1, 1249.0, 1128.8,1106.7, 1048.9, 1007.4 


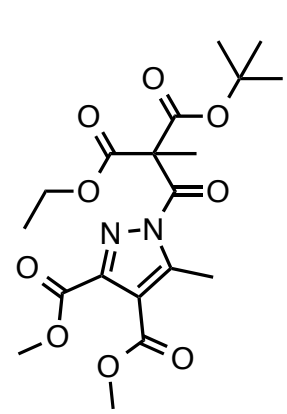

dimethyl

1-(3-(tert-butoxy)-2-(ethoxycarbonyl)-2-methyl-3oxopropanoyl)-5-methyl-1H-pyrazole-3,4-dicarboxylate (compound i): To an oven dried 1.5 dram vial was added a stir bar and $46.3 \mathrm{mg}(0.163 \mathrm{mmol})$ of the diazo malonate, and $1.5 \mathrm{~mL}$ of dry benzene. The reaction vial was then evacuated of air and refilled with nitrogen 3 times. The reaction mixture was stirred for 10 minutes at R.T. then placed in an aluminum heating block set to $50{ }^{\circ} \mathrm{C}$ for 24 hours. After 24 hours the solvent was then evaporated under reduced pressure and the crude reaction mixture maybe purified by flash chromatography using a gradient beginning at 0\% EtOAc : hexanes and progressing to $10 \%$ EtOAc : hexanes. $66.8 \mathrm{mg}$ $(96.3 \%)$ of the purified product was isolated as a clear viscous oil.

${ }^{1}$ H NMR (400 MHz, Benzene- $d_{6}$ ) $\delta 4.02$ (qd, $\left.J=7.1,4.0 \mathrm{~Hz}, 1 \mathrm{H}\right), 3.45$ (s, $\left.1 \mathrm{H}\right), 3.36(\mathrm{~s}, 2 \mathrm{H}), 2.62$ (s, 1H), $2.07(\mathrm{~s}, 1 \mathrm{H}), 1.34$ (s, 4H), 0.93 (t, $J=7.1 \mathrm{~Hz}, 2 \mathrm{H}$ ).

${ }^{13} \mathrm{C}$ NMR (101 MHz, Chloroform-d) $\delta 168.58,167.16,165.34,162.57,162.35,148.64,145.65$ , $114.59,83.53,63.95,62.41,52.90,52.30,27.68,20.40,13.93,13.24$.

+ESI-HRMS $\mathrm{m} / \mathrm{z}$ : calc'd for $\left(\mathrm{M}+\mathrm{Na}^{+}\right) \mathrm{C}_{19} \mathrm{H}_{26} \mathrm{~N}_{2} \mathrm{O}_{9} \mathrm{Na}^{+}=449.15360$, found $\mathrm{C}_{19} \mathrm{H}_{26} \mathrm{~N}_{2} \mathrm{O}_{9} \mathrm{Na}^{+}=$ 449.15320

FTIR (Neat): 2980.5, 2955.9, 1726.8, 1572.5, 1449.6,1370.2, 1341.8, 1311.6, 1218.7, 1167.8, $1108.6,1089.2,1016.2,961.2,892.7,843.9,807.9,790.8,780.1,726.7,660.2$ 
H NMR, C NMR \& IR Spectral Data 


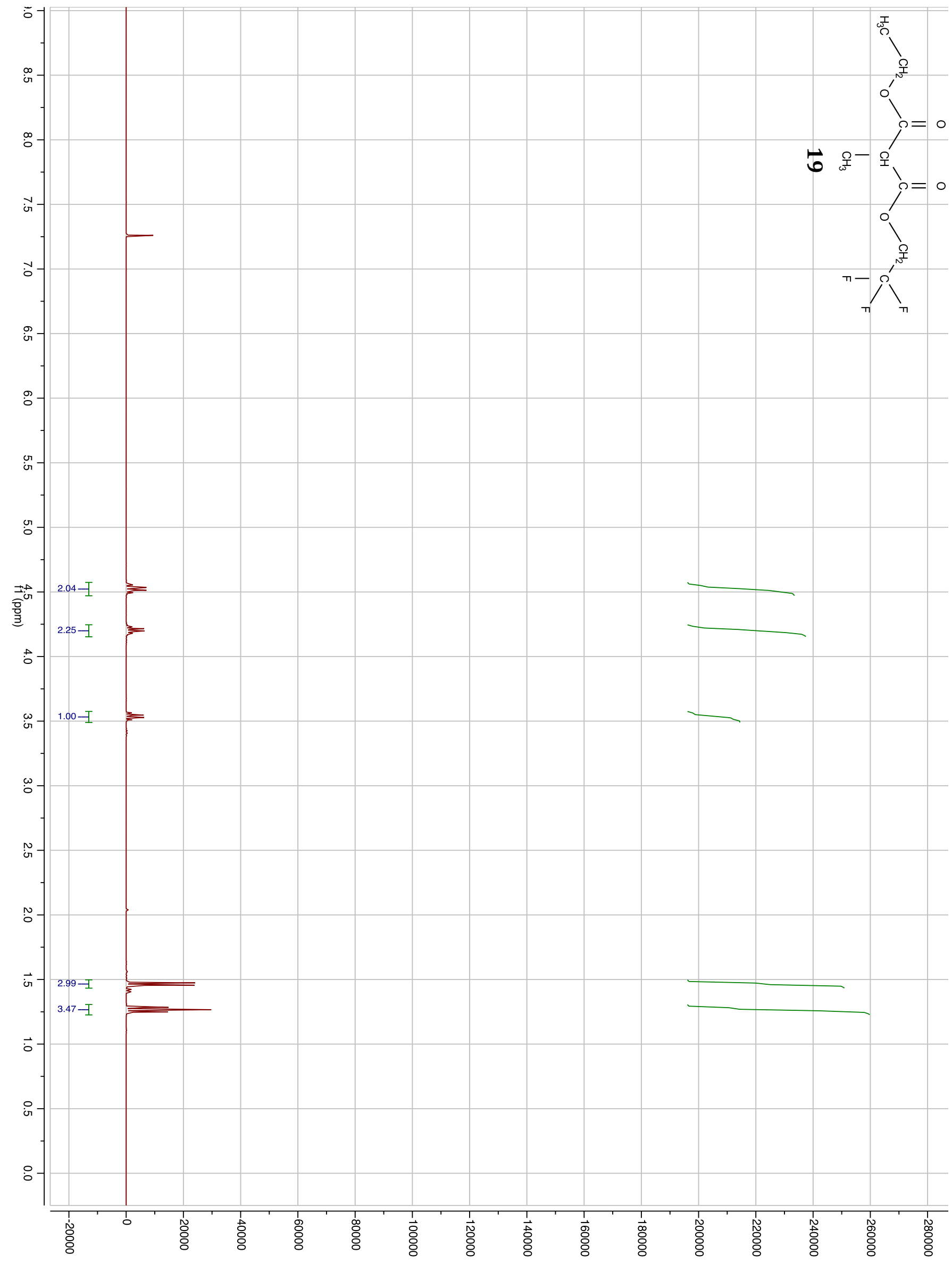

S26 


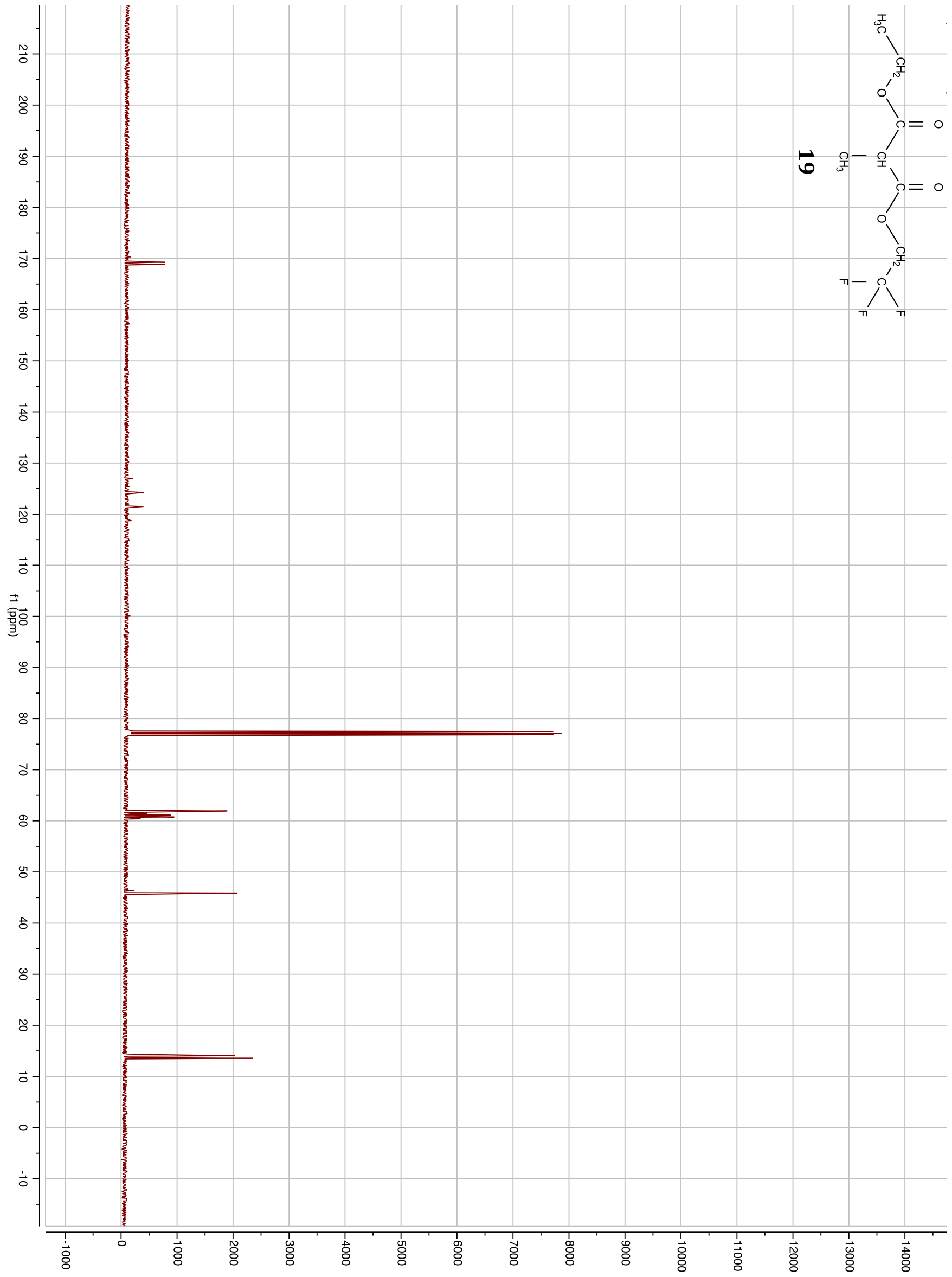




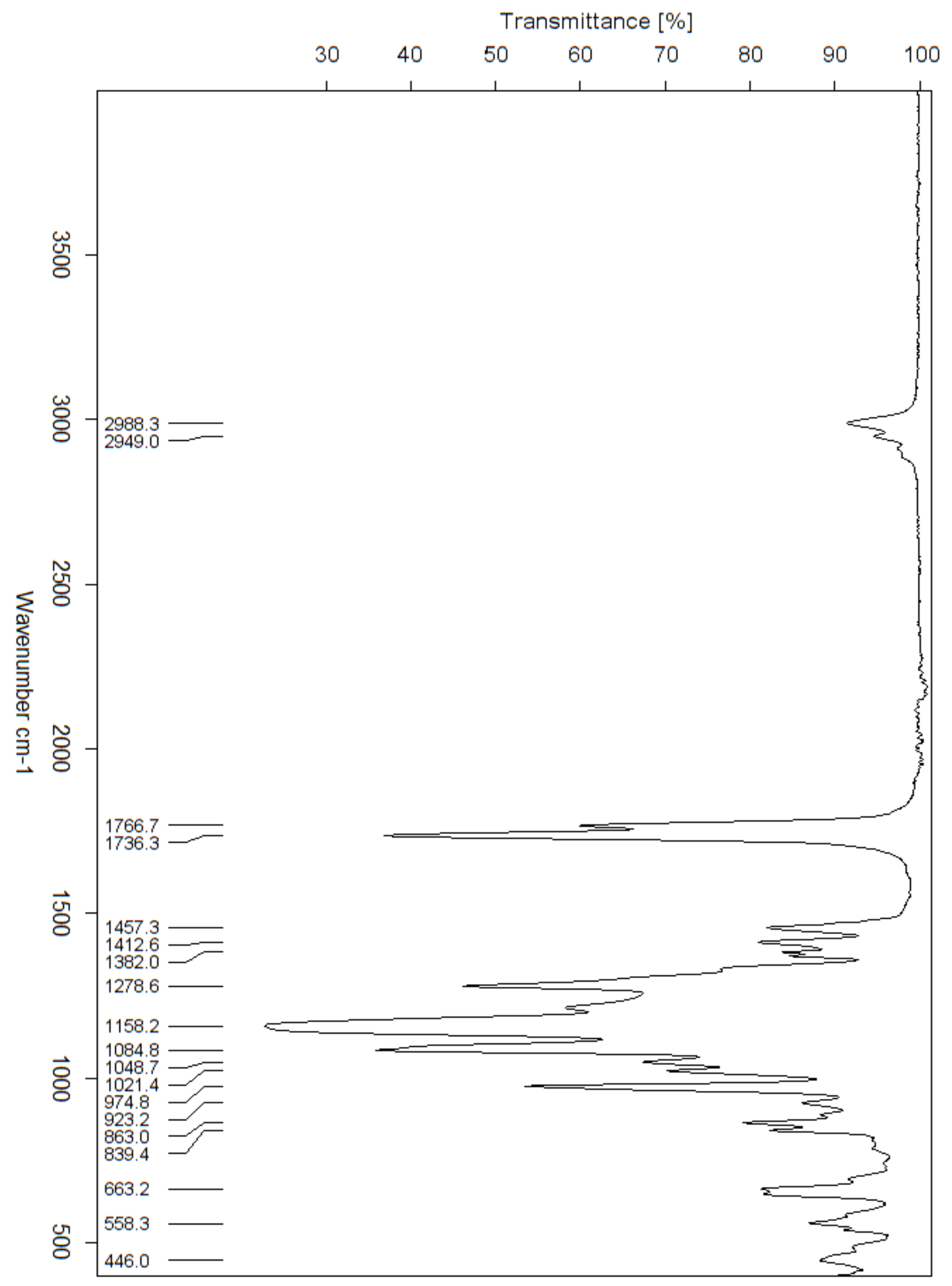




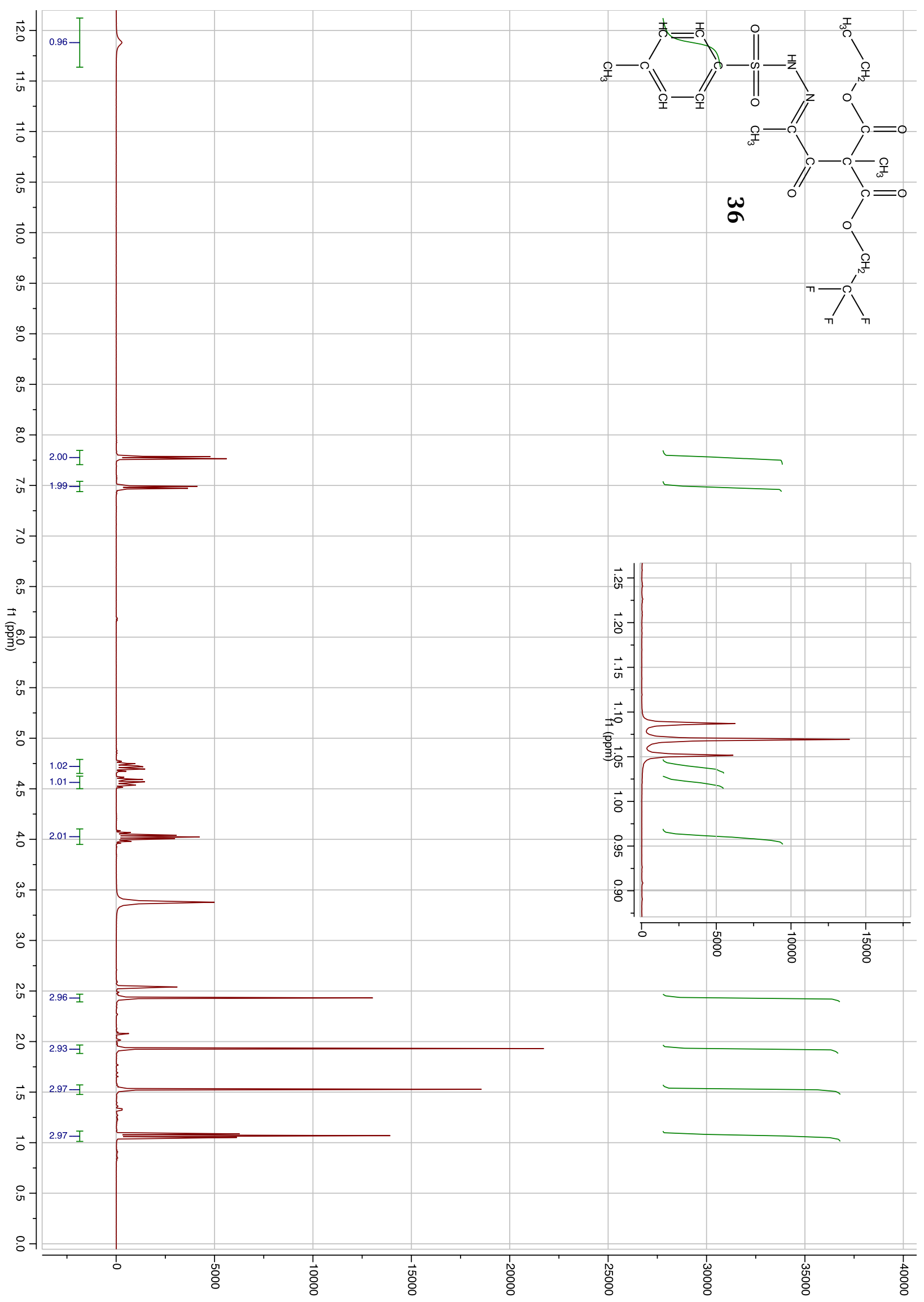




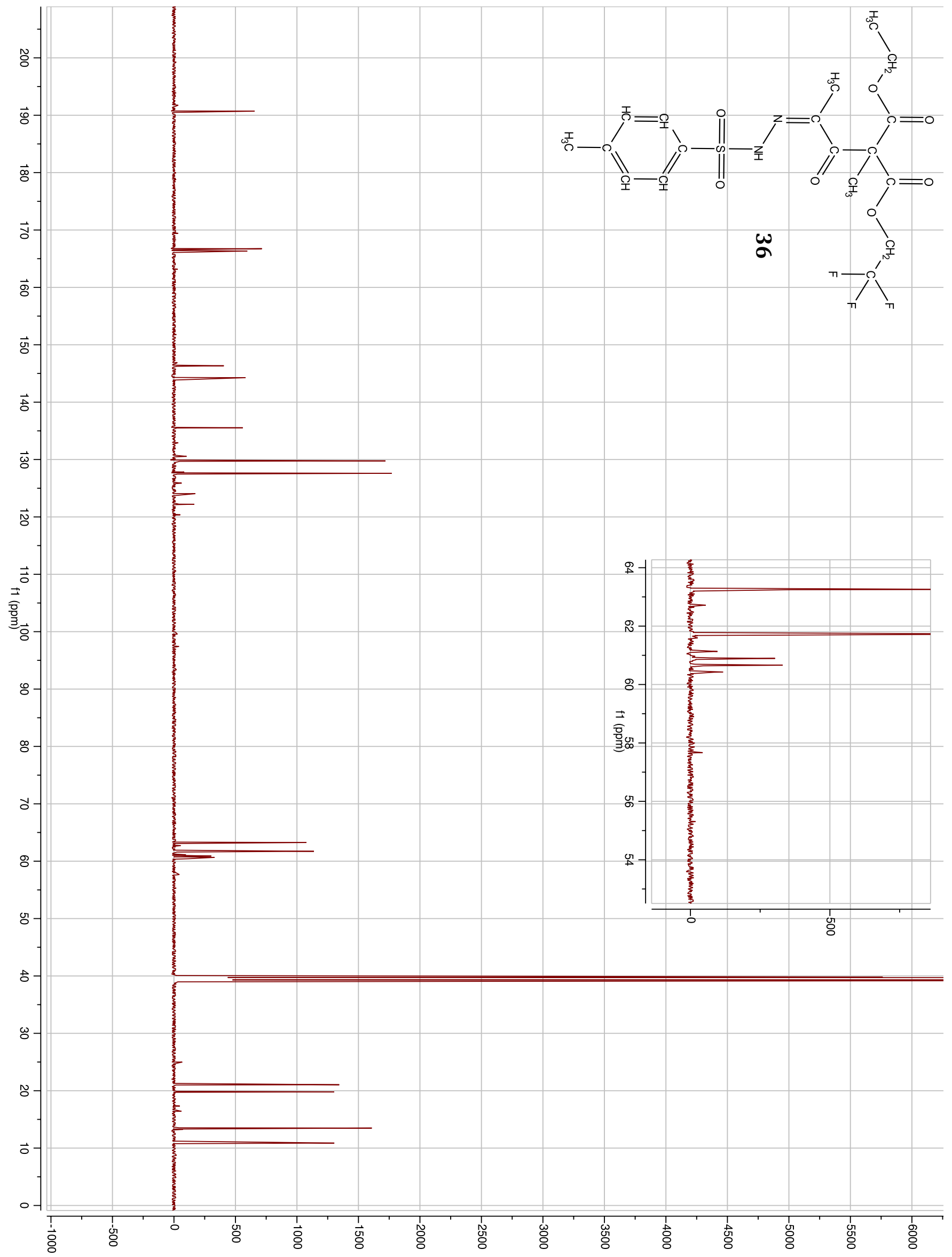


Transmittance [\%]

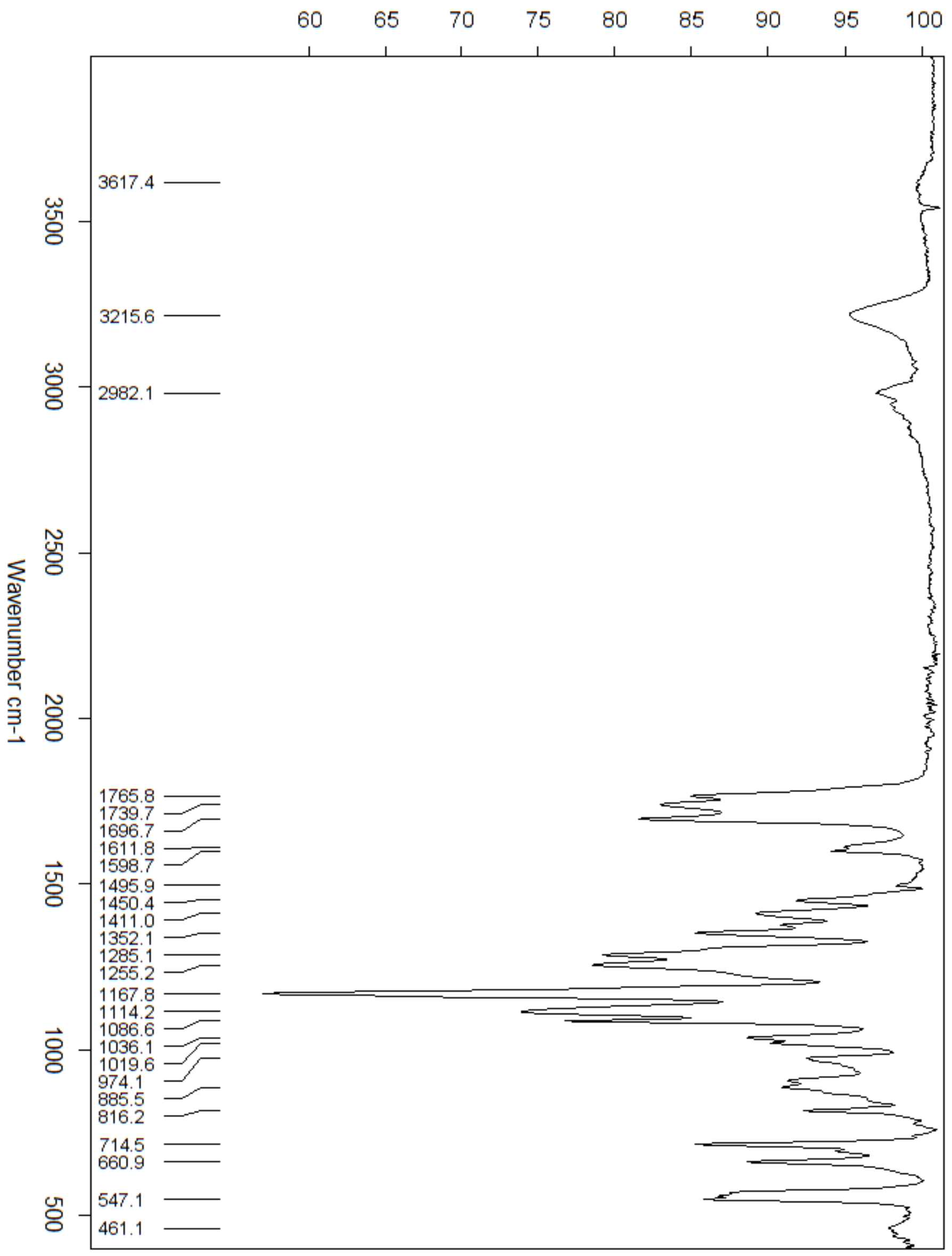




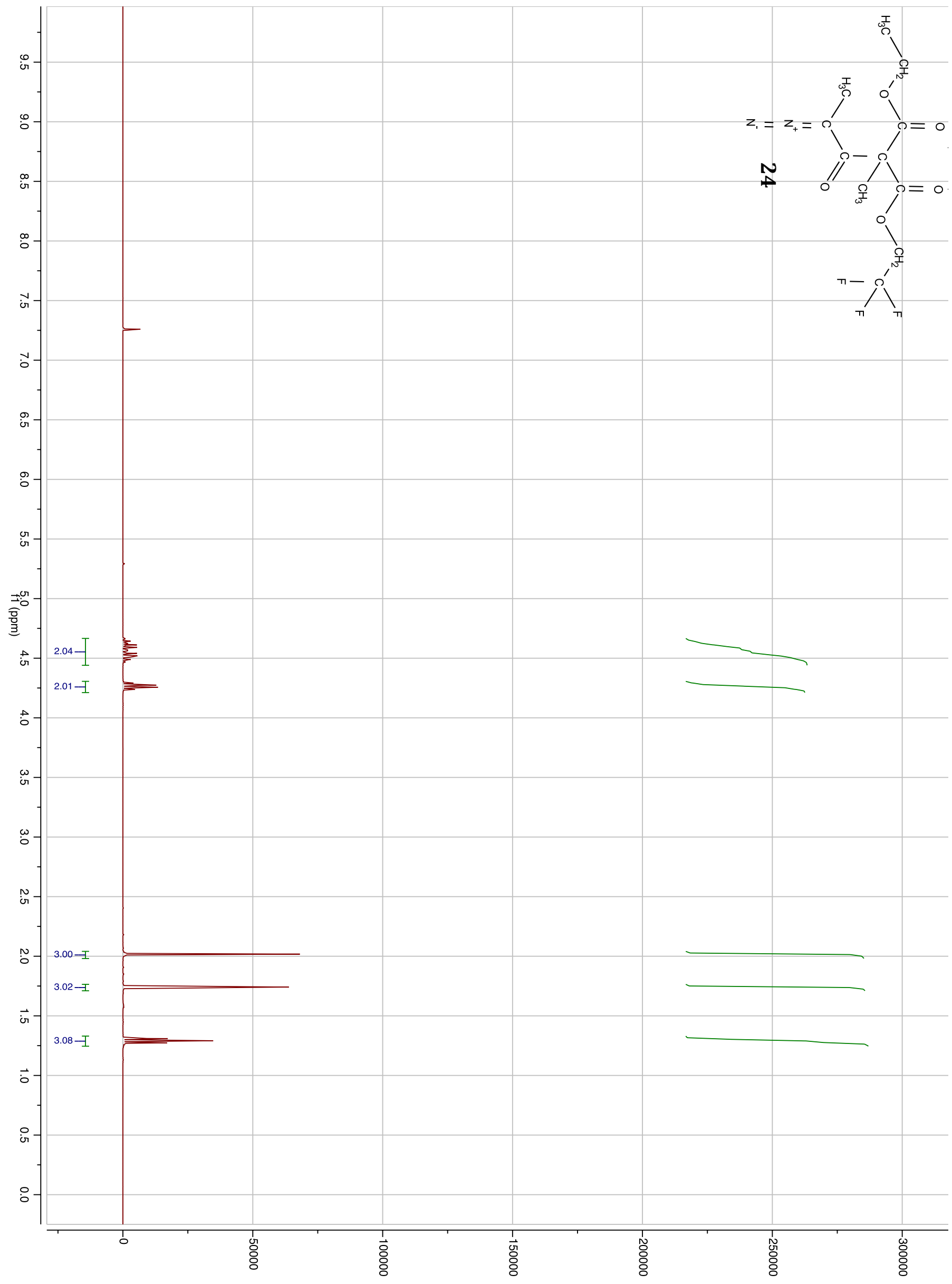




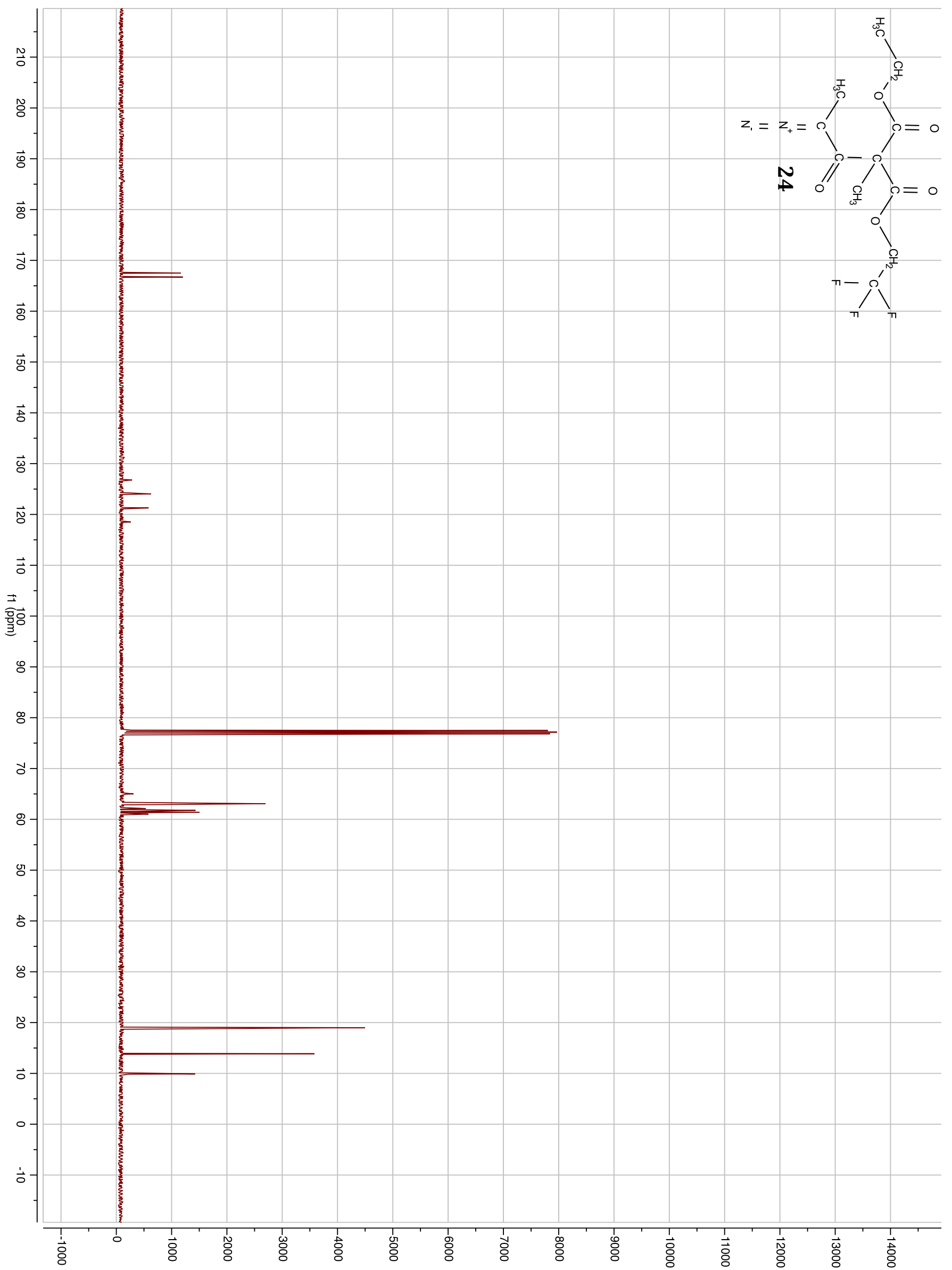




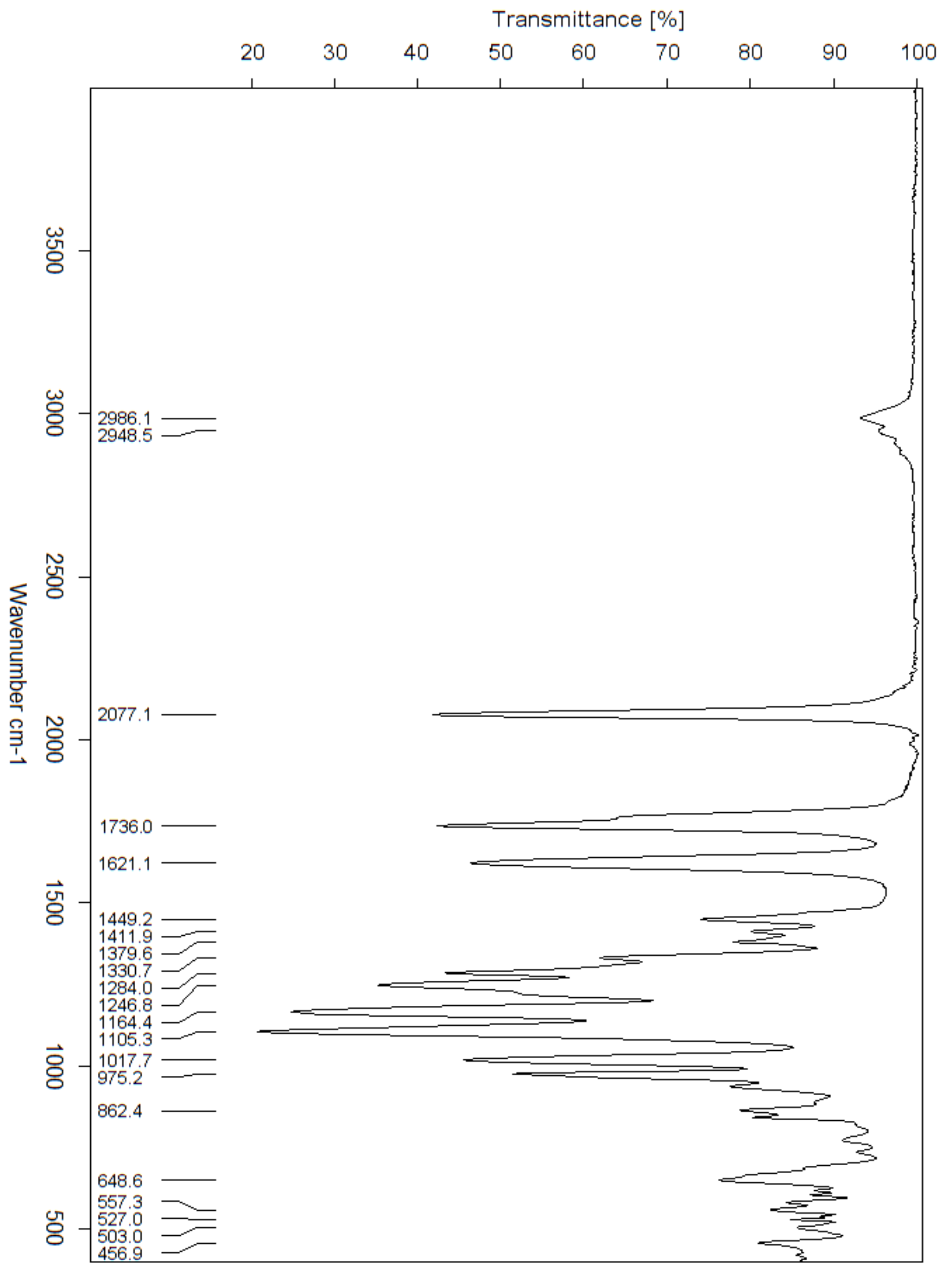




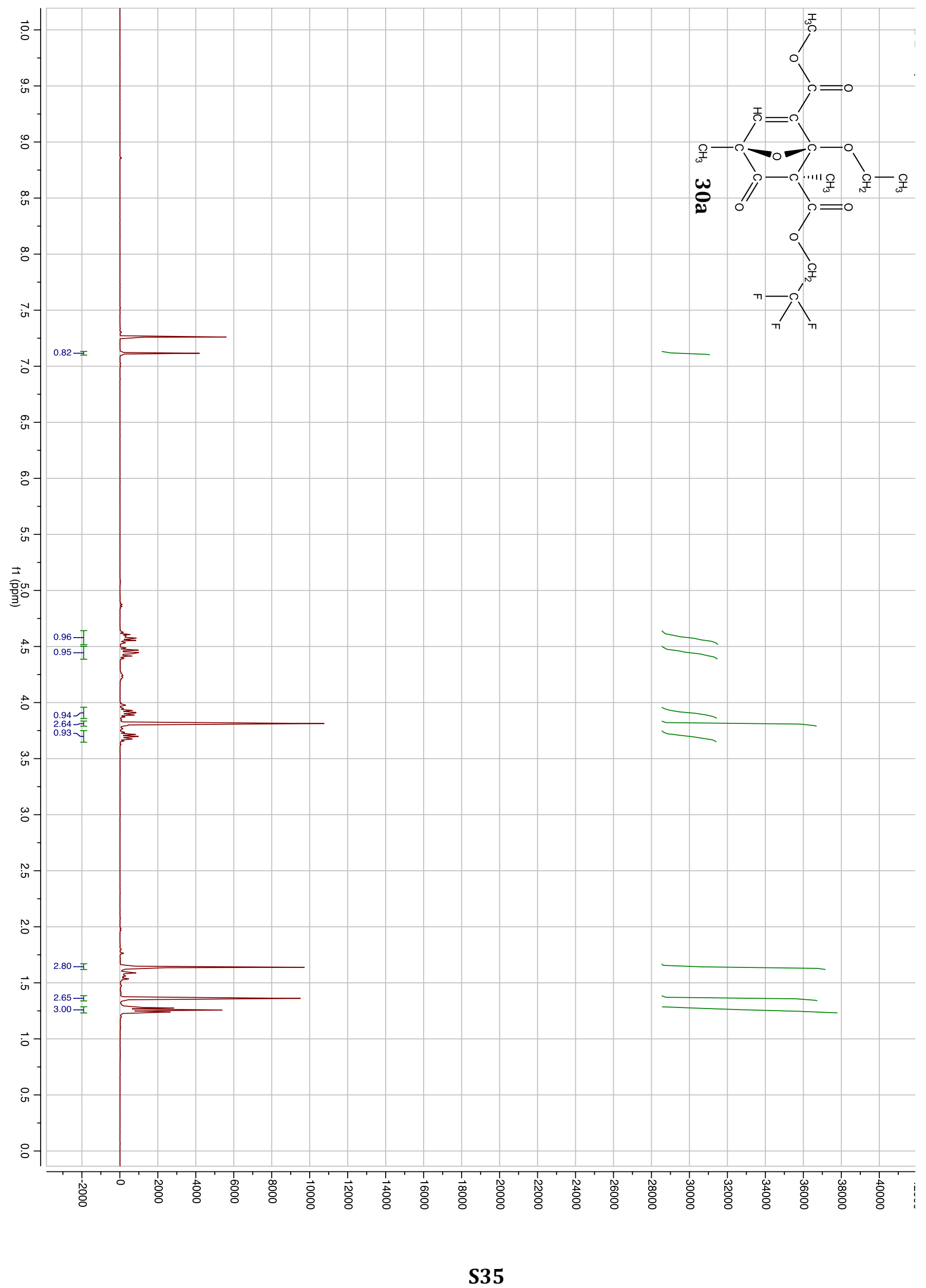




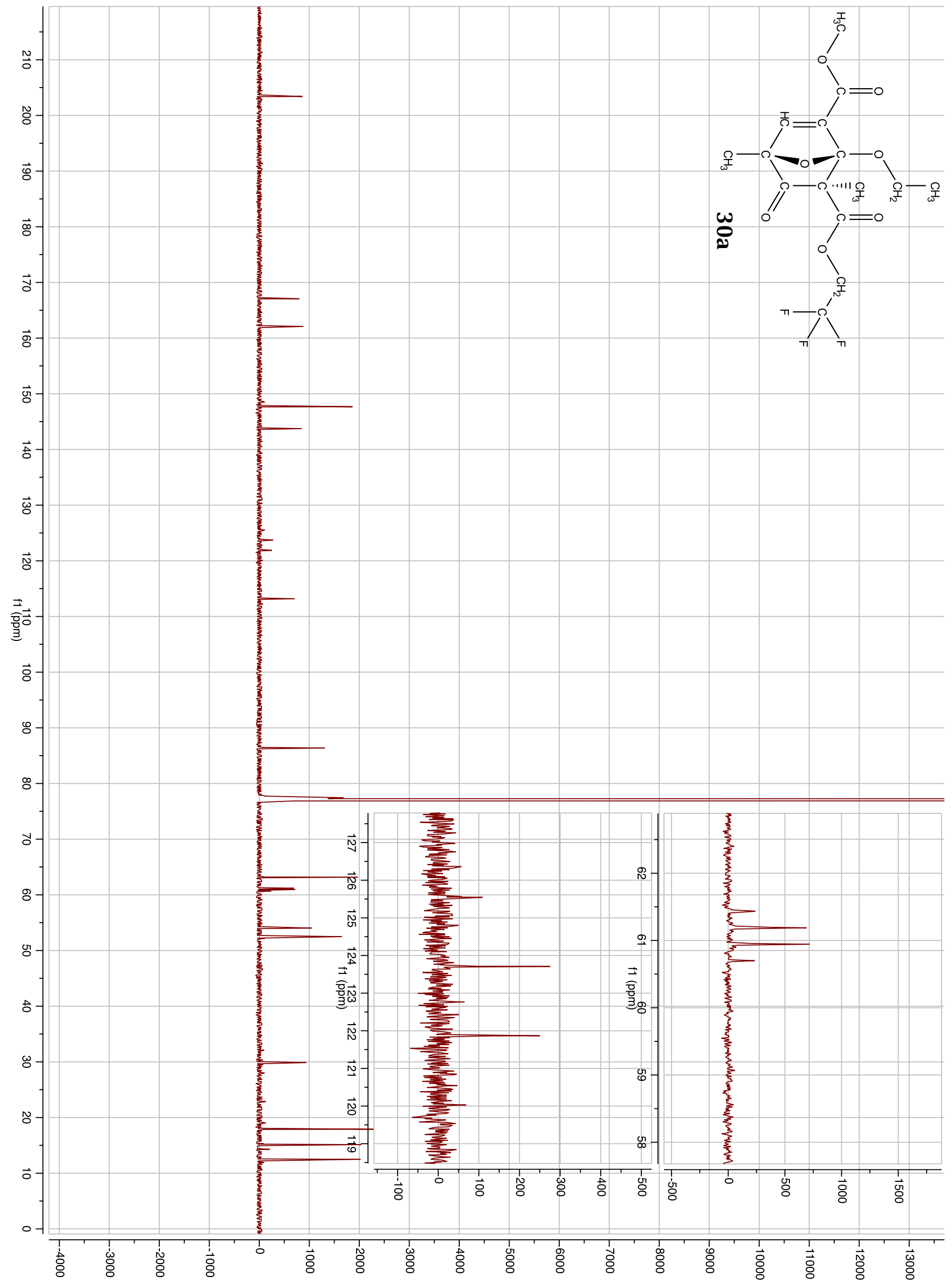




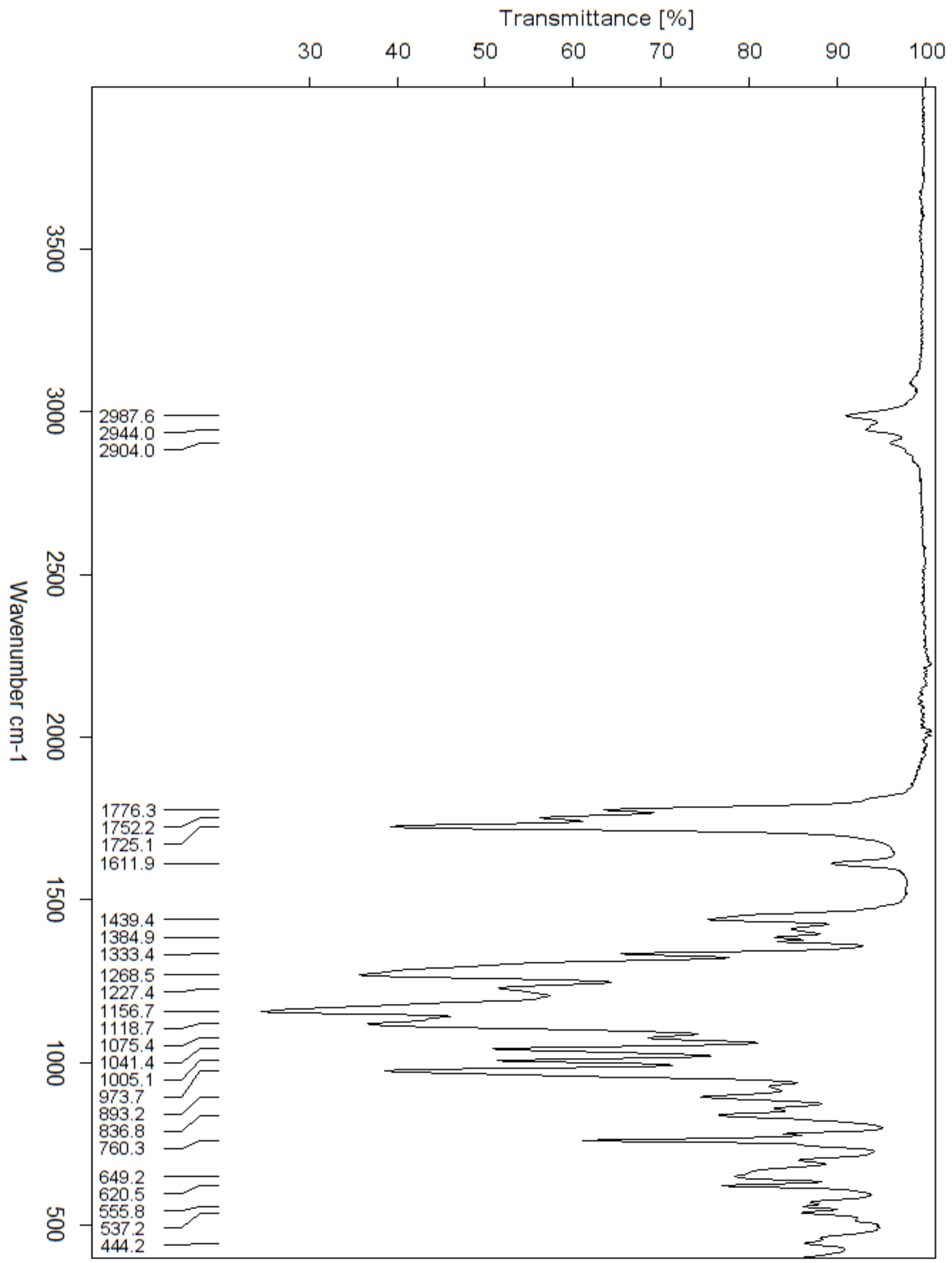




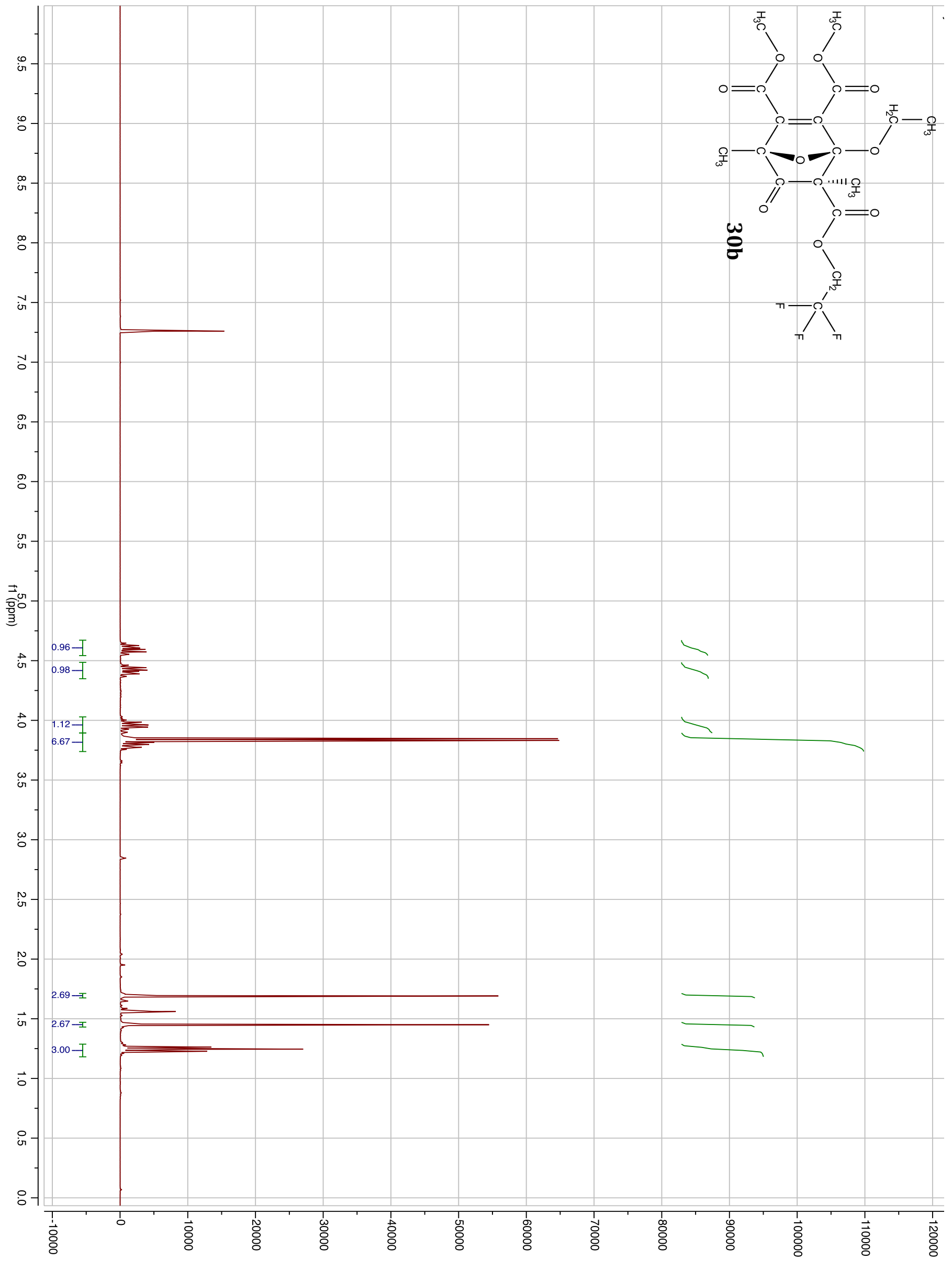




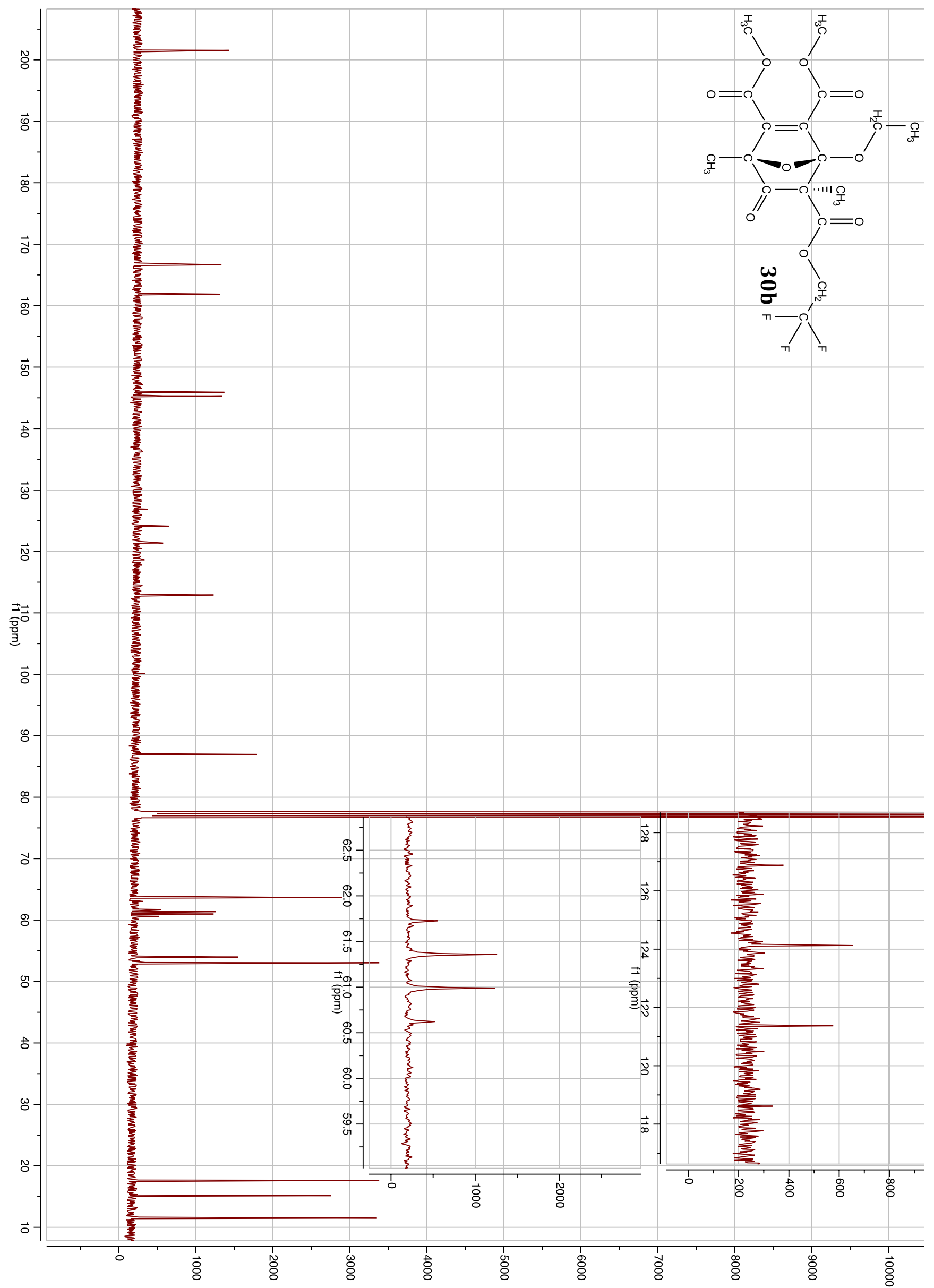




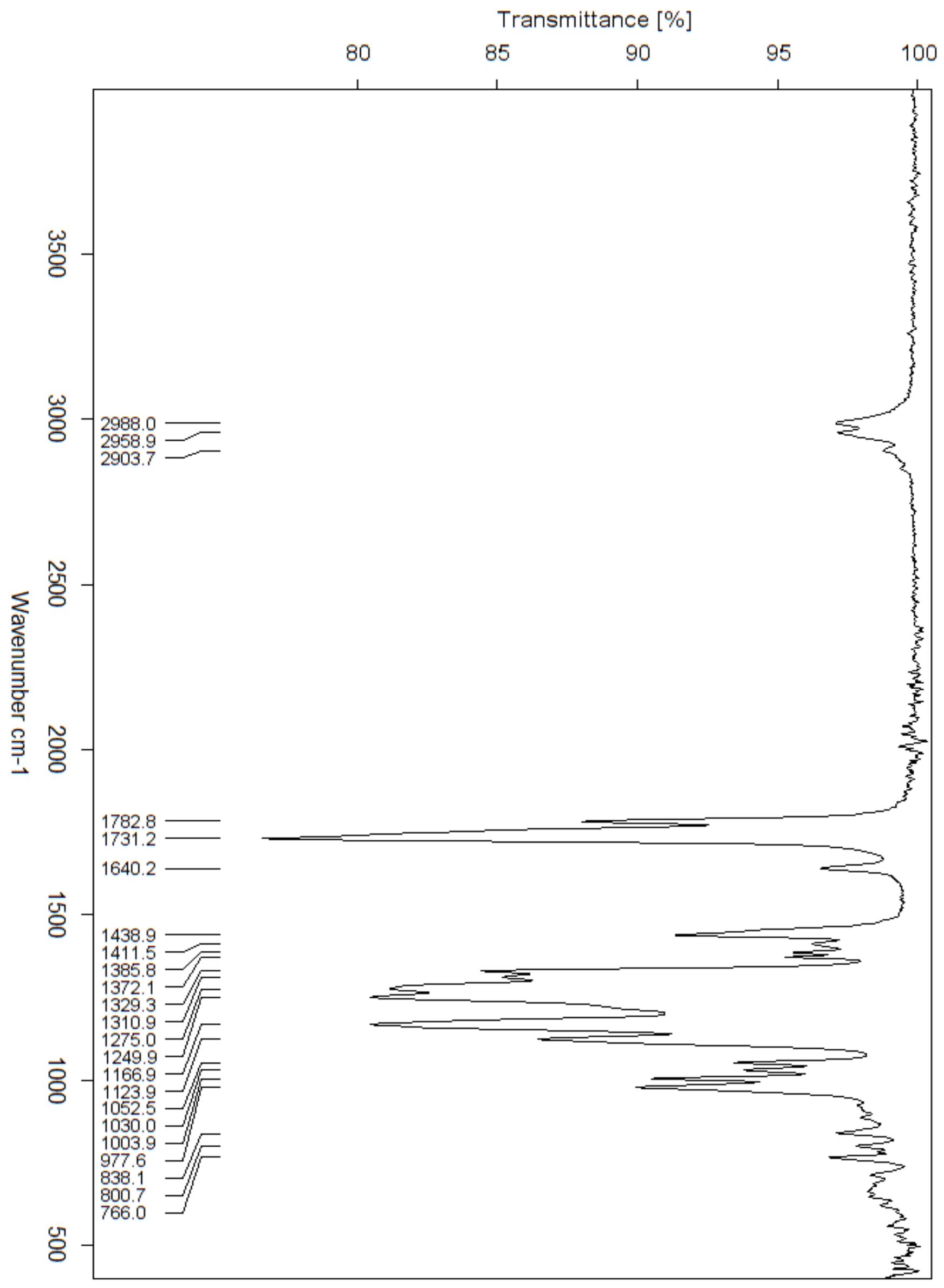




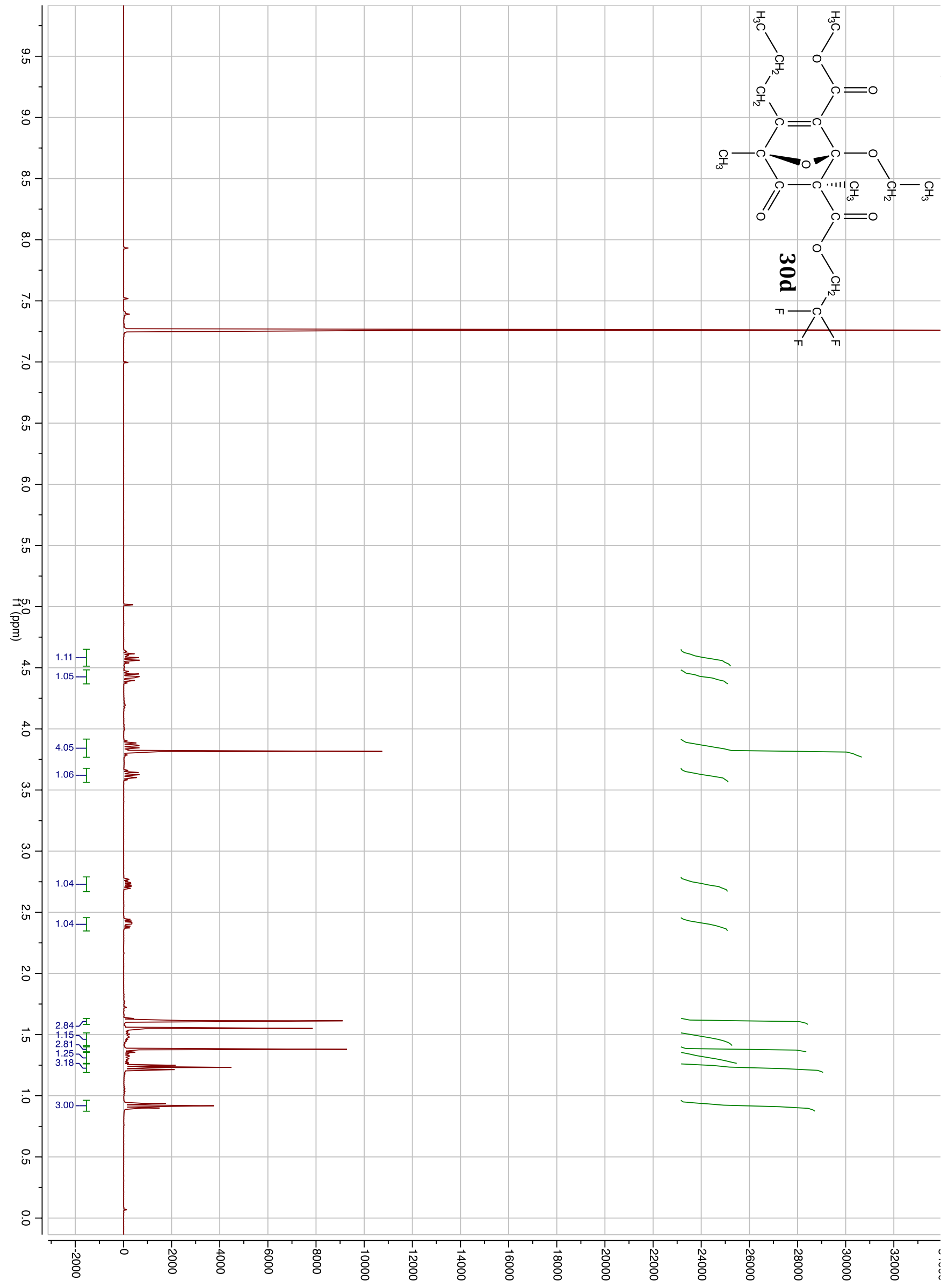




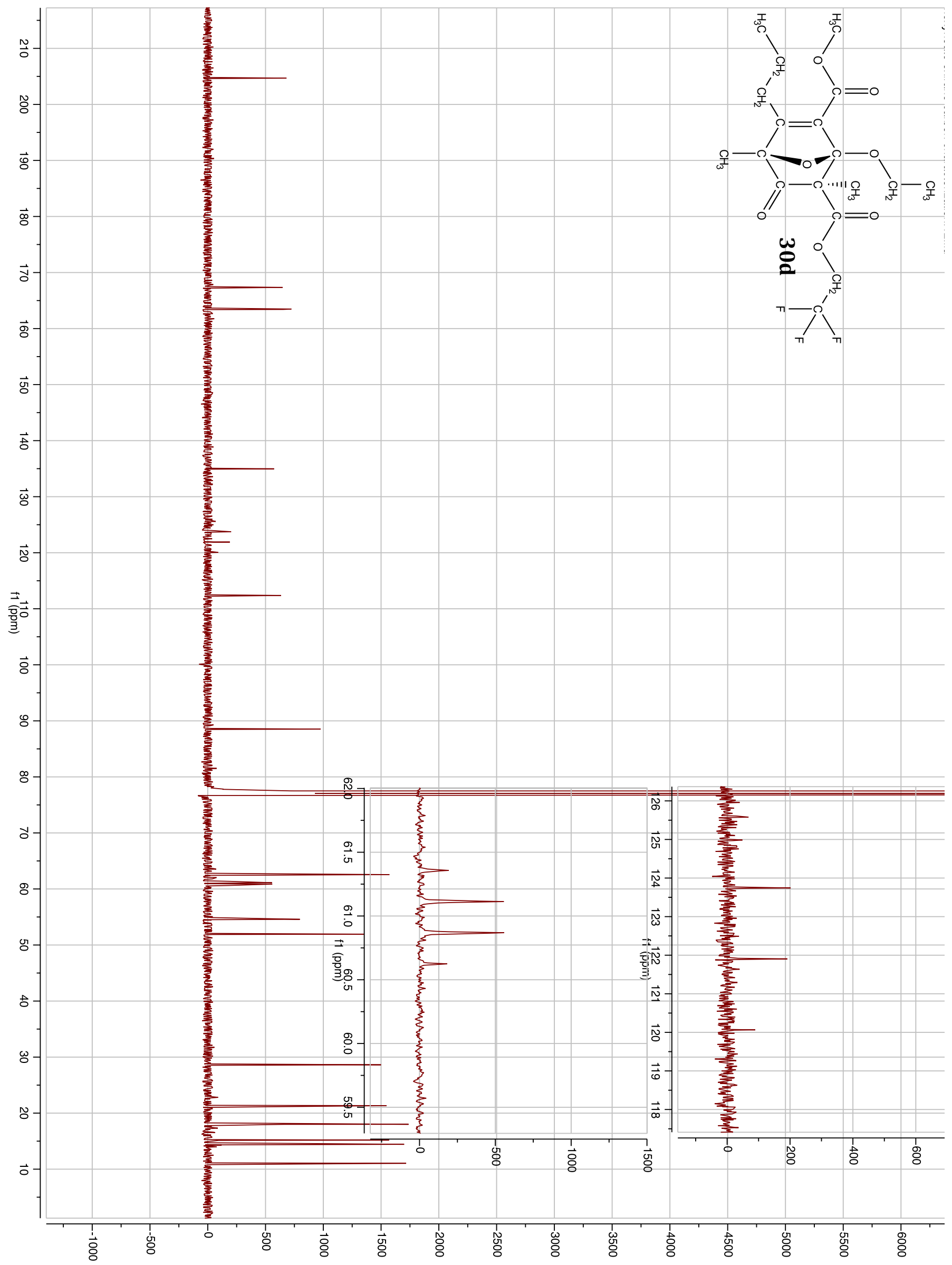




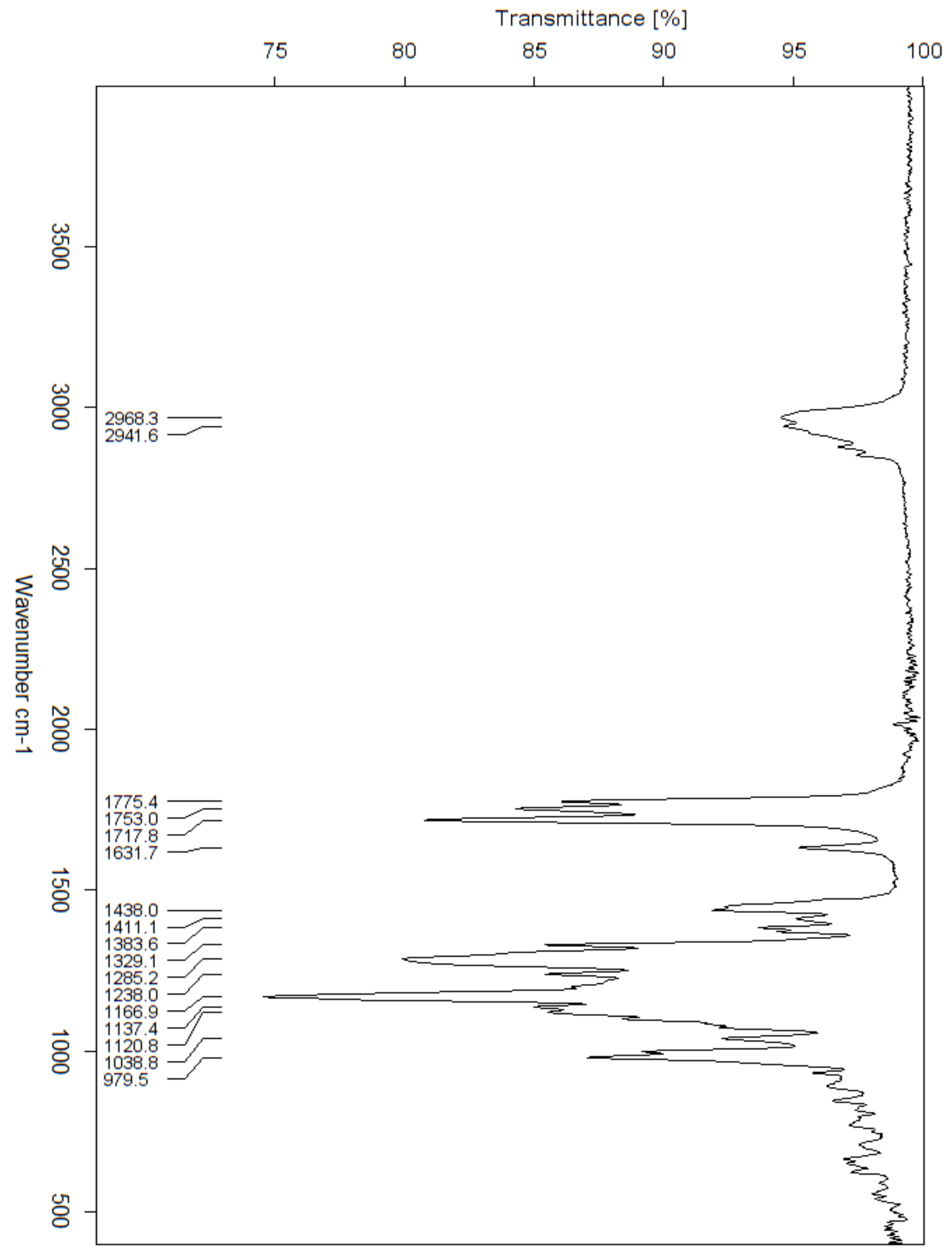




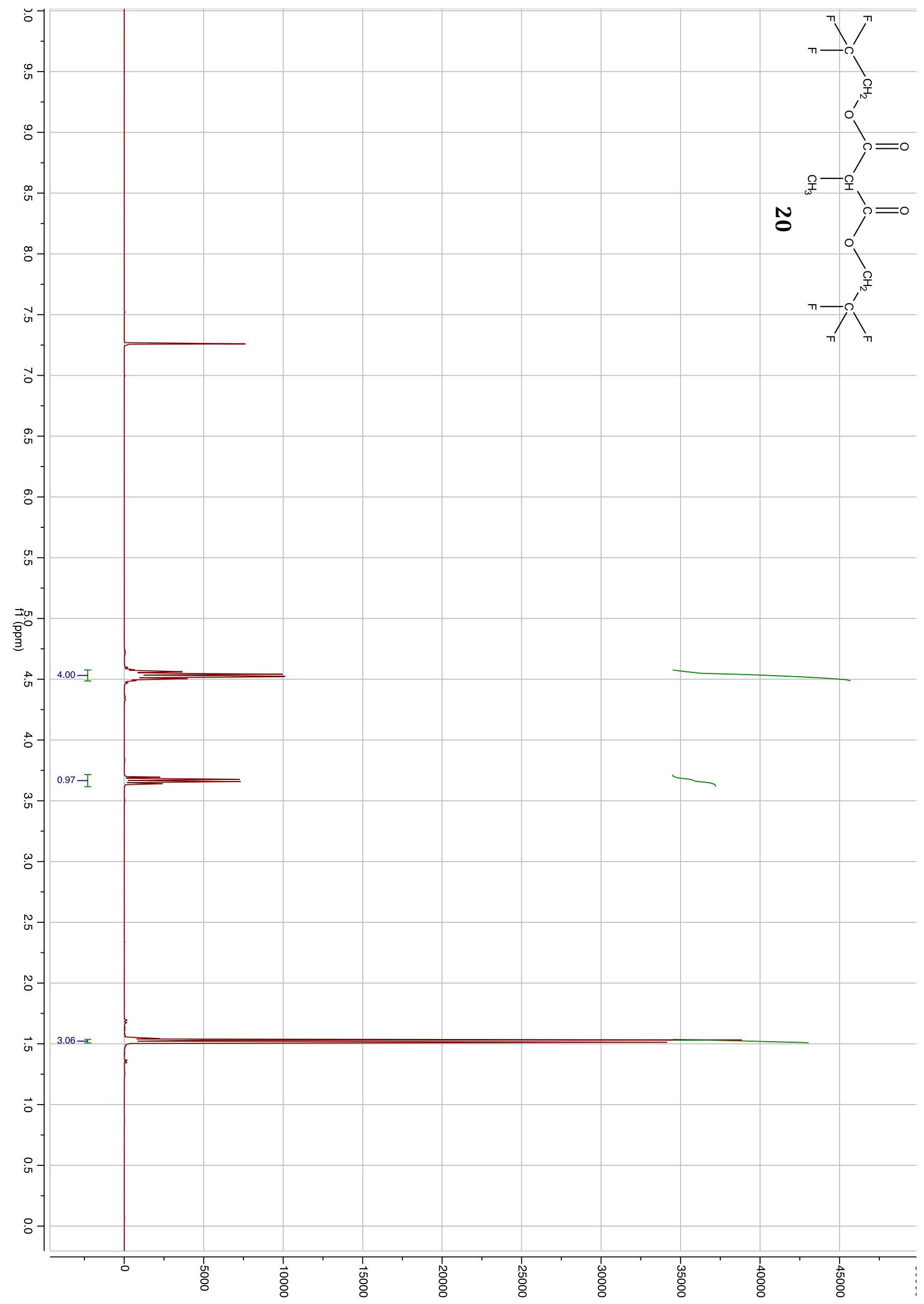




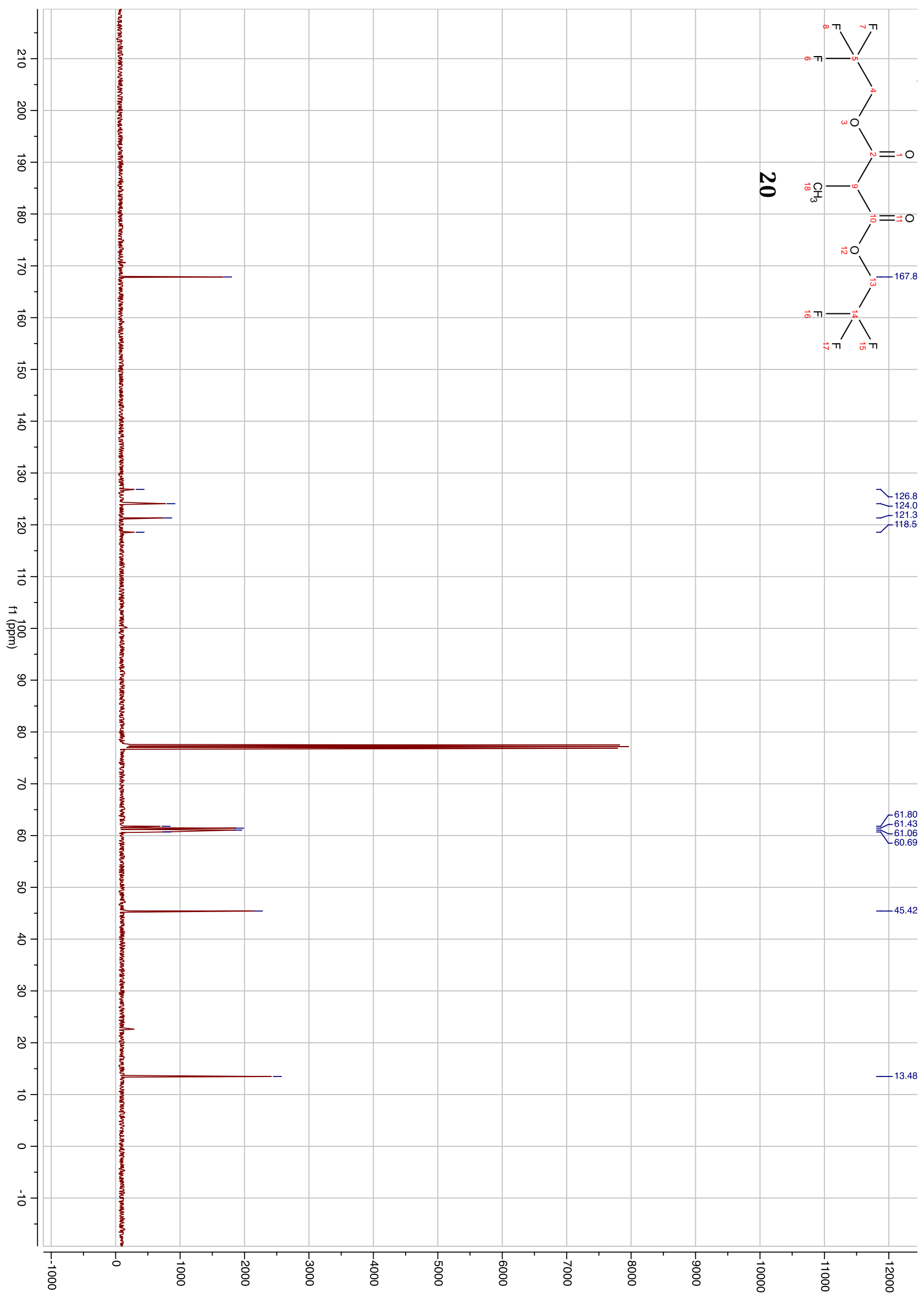




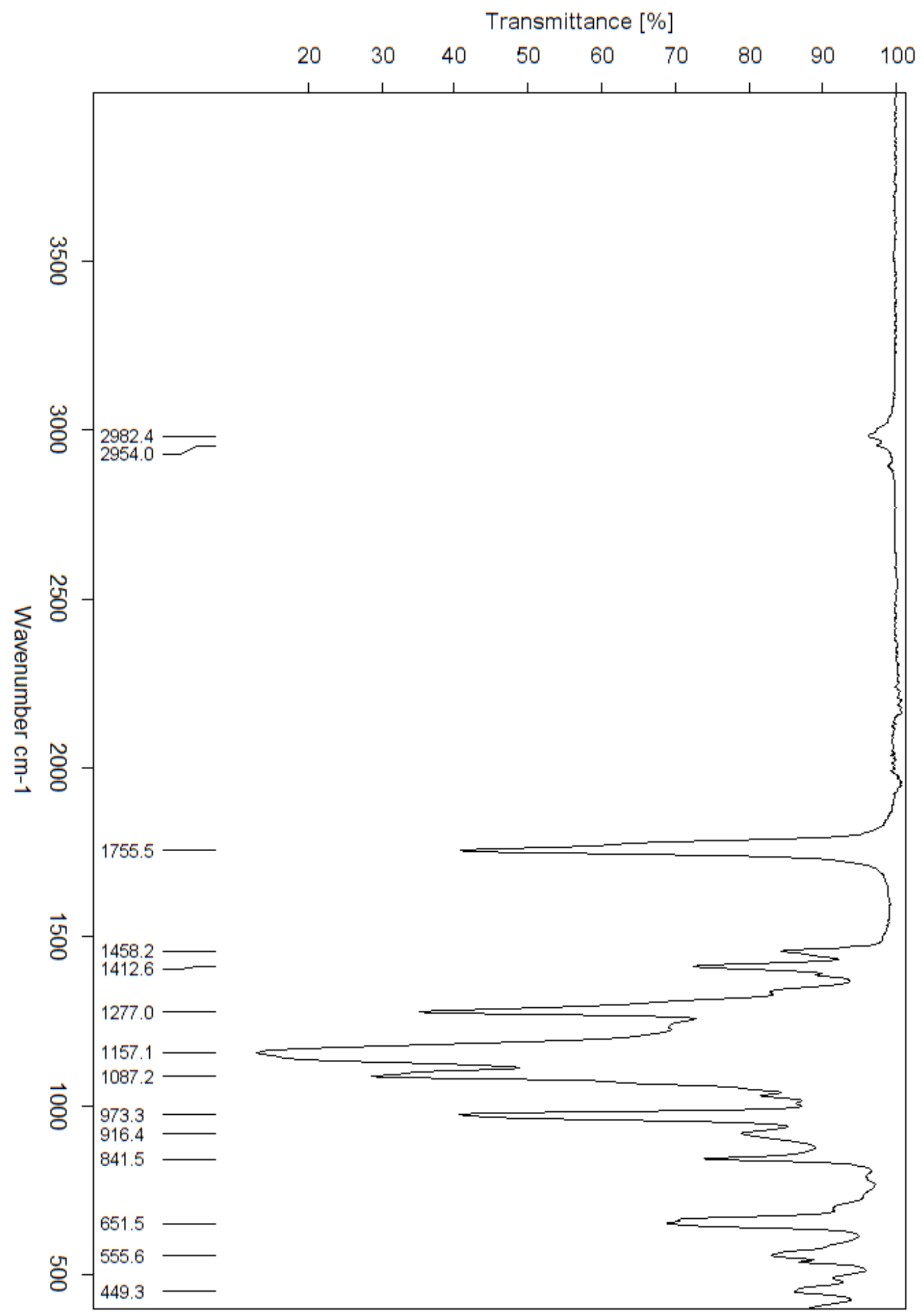




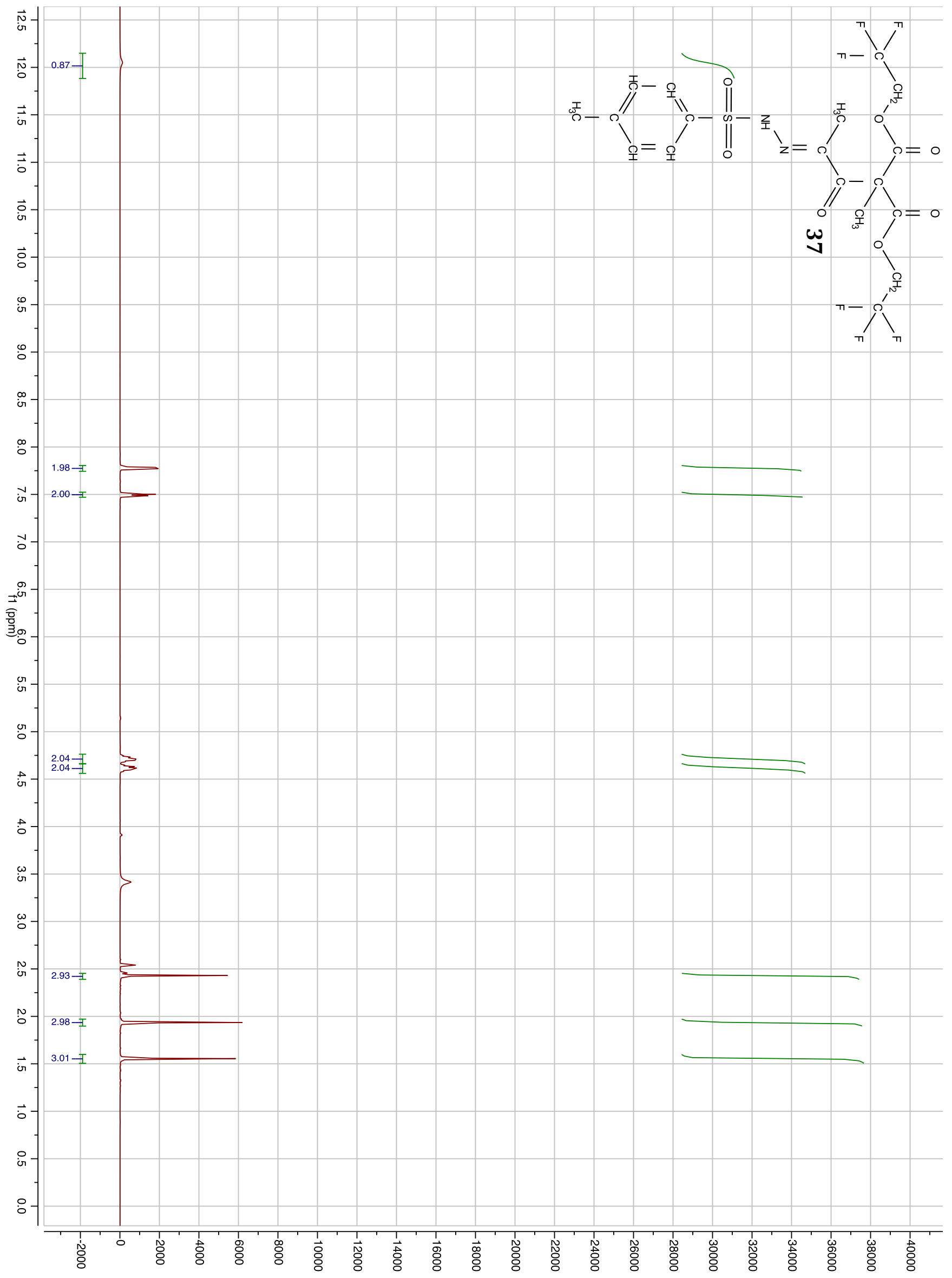




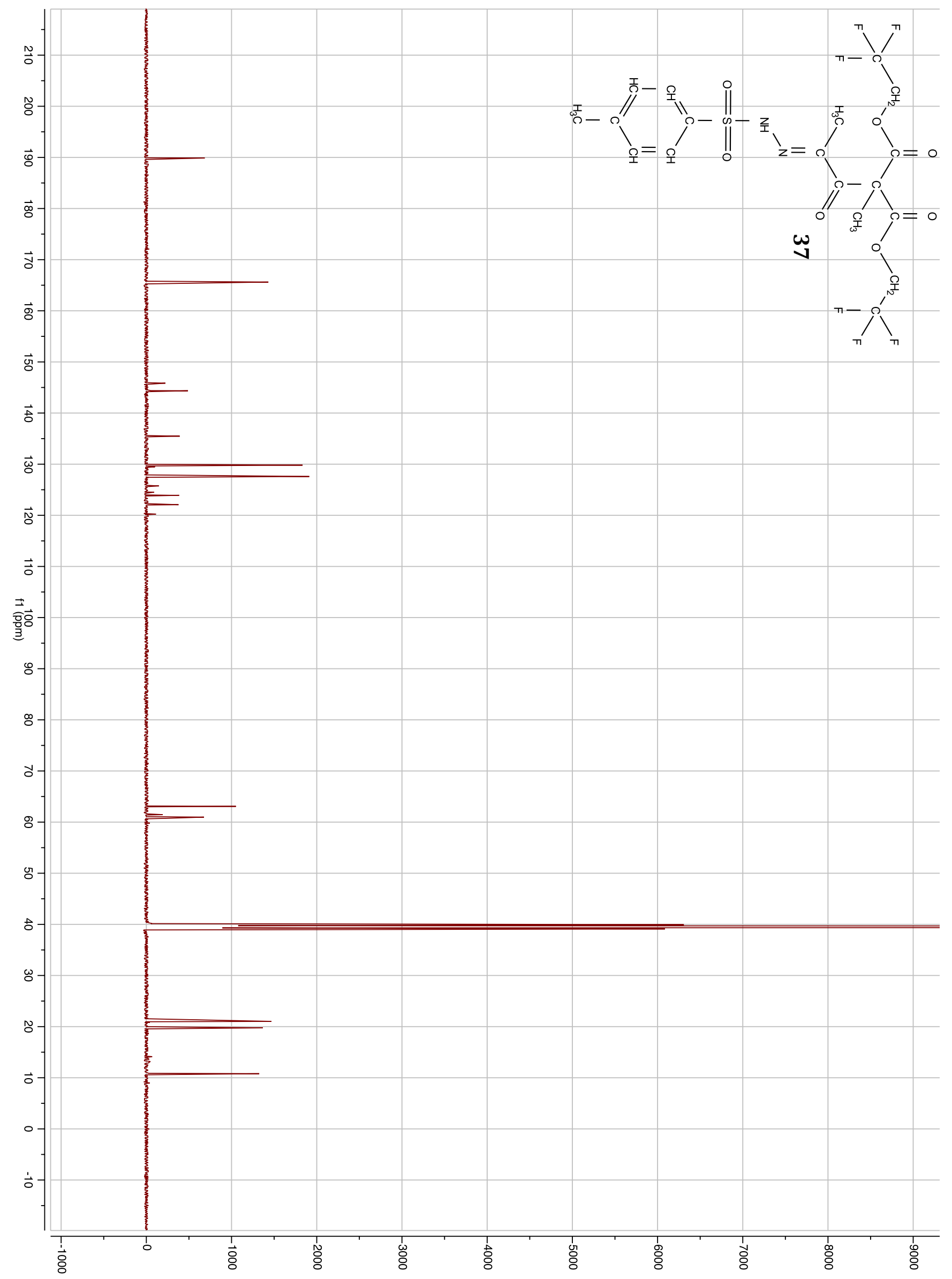




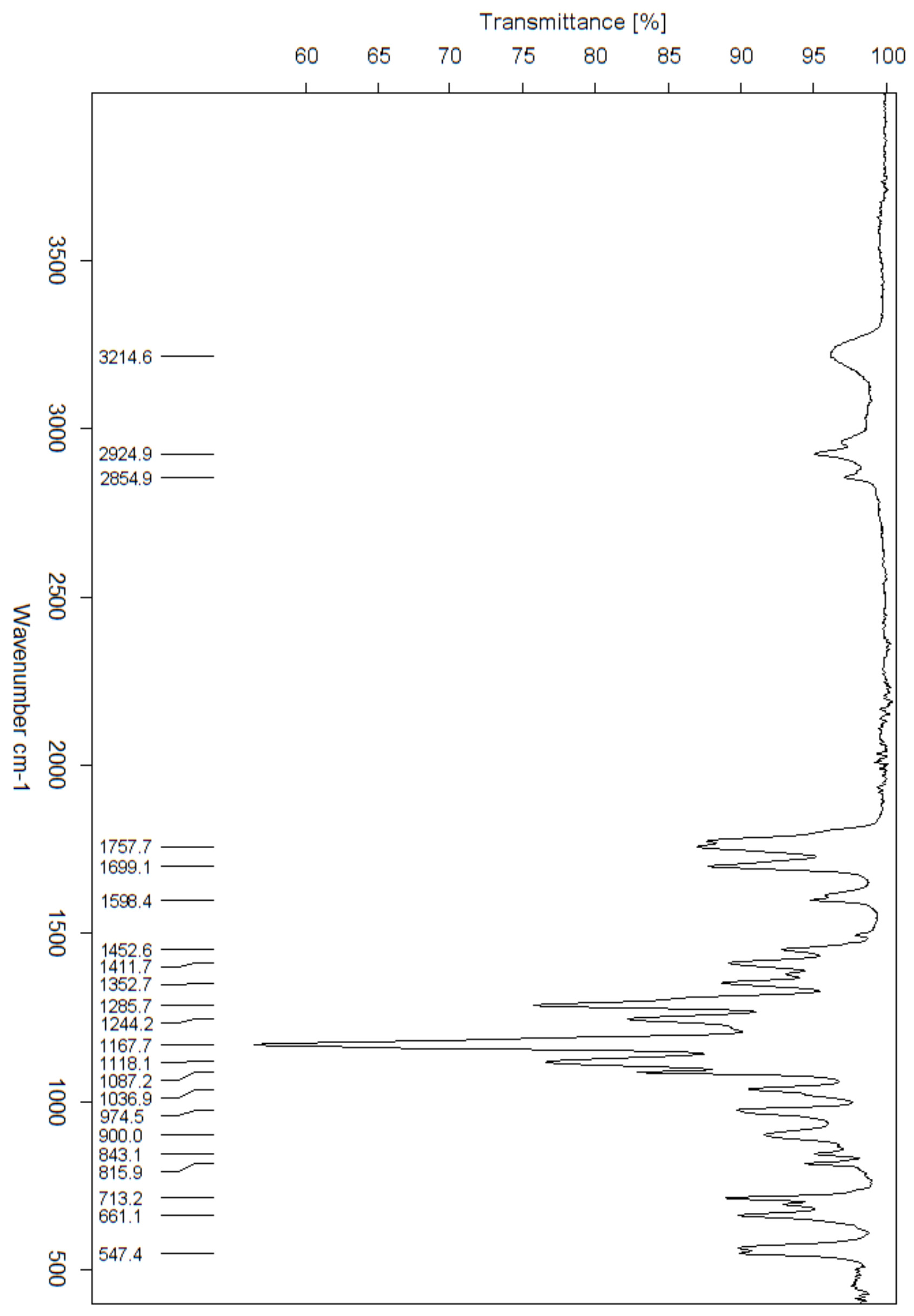




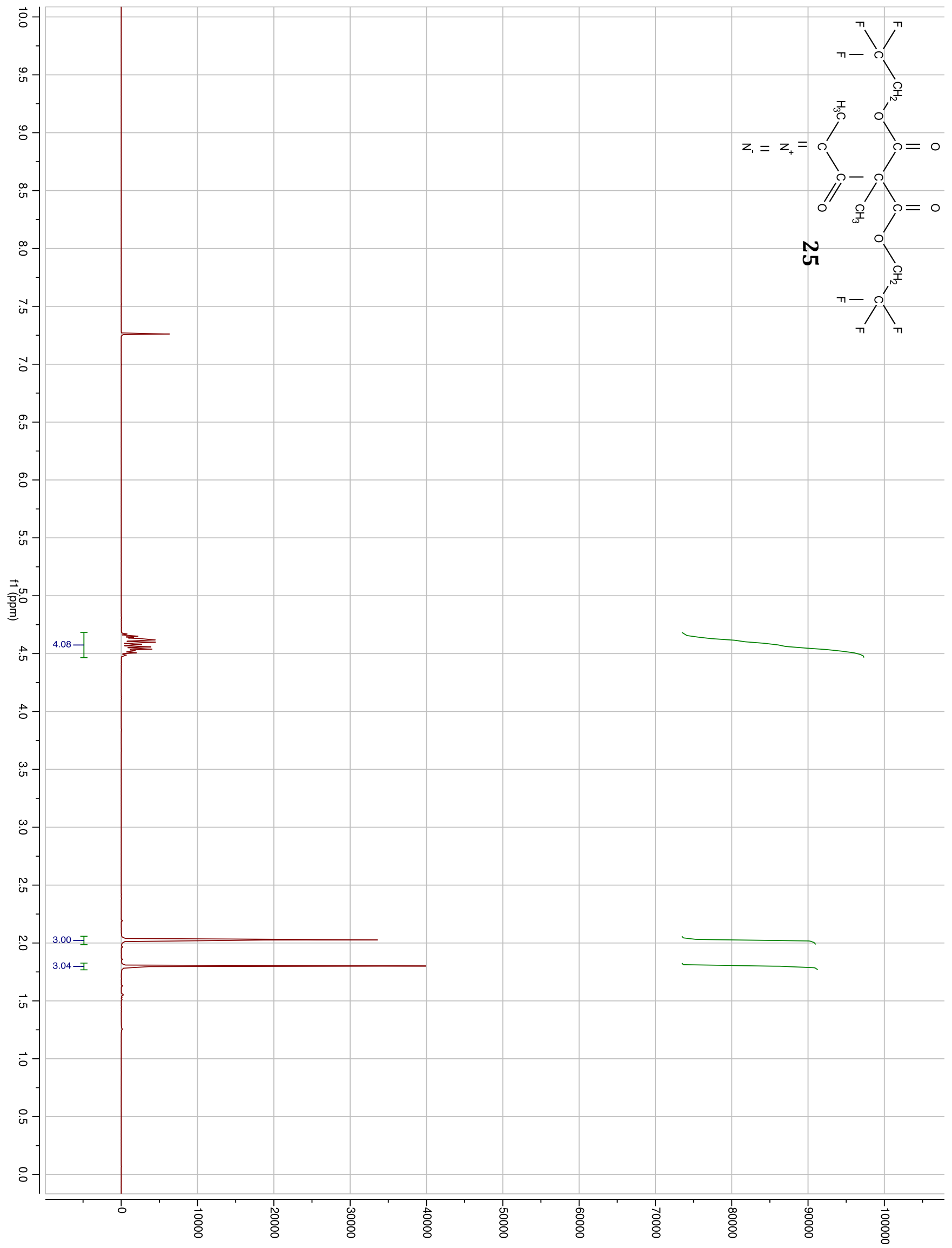




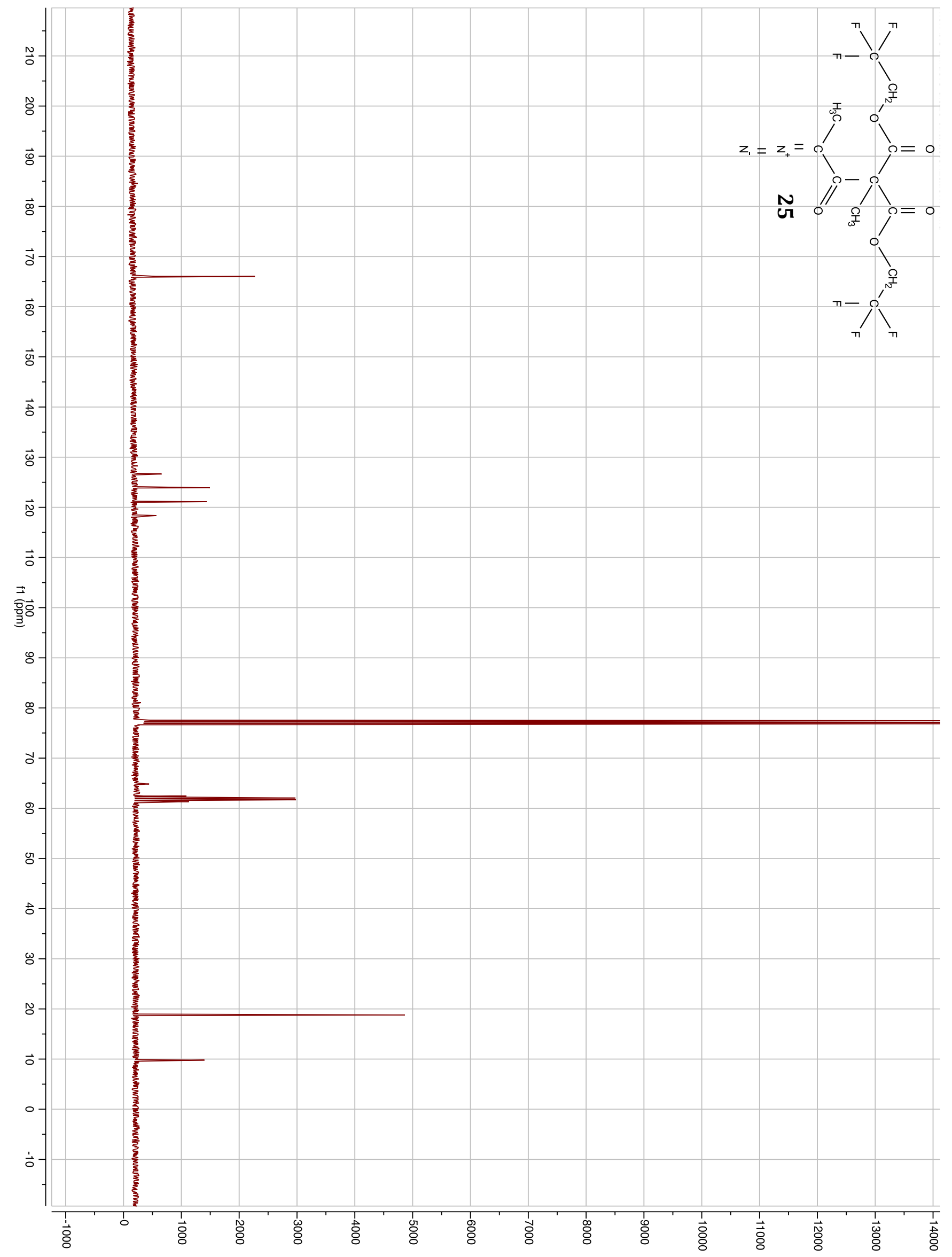




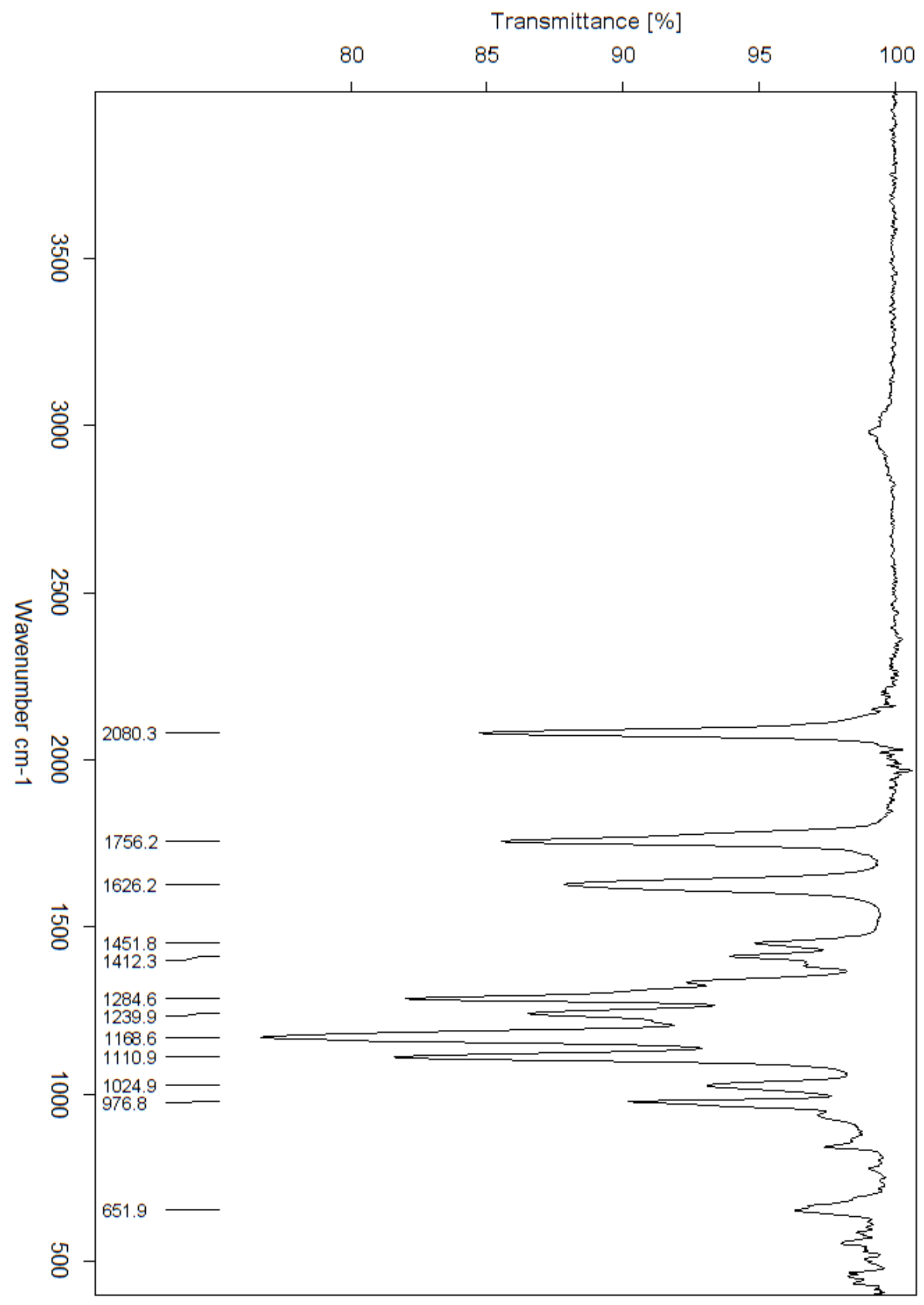




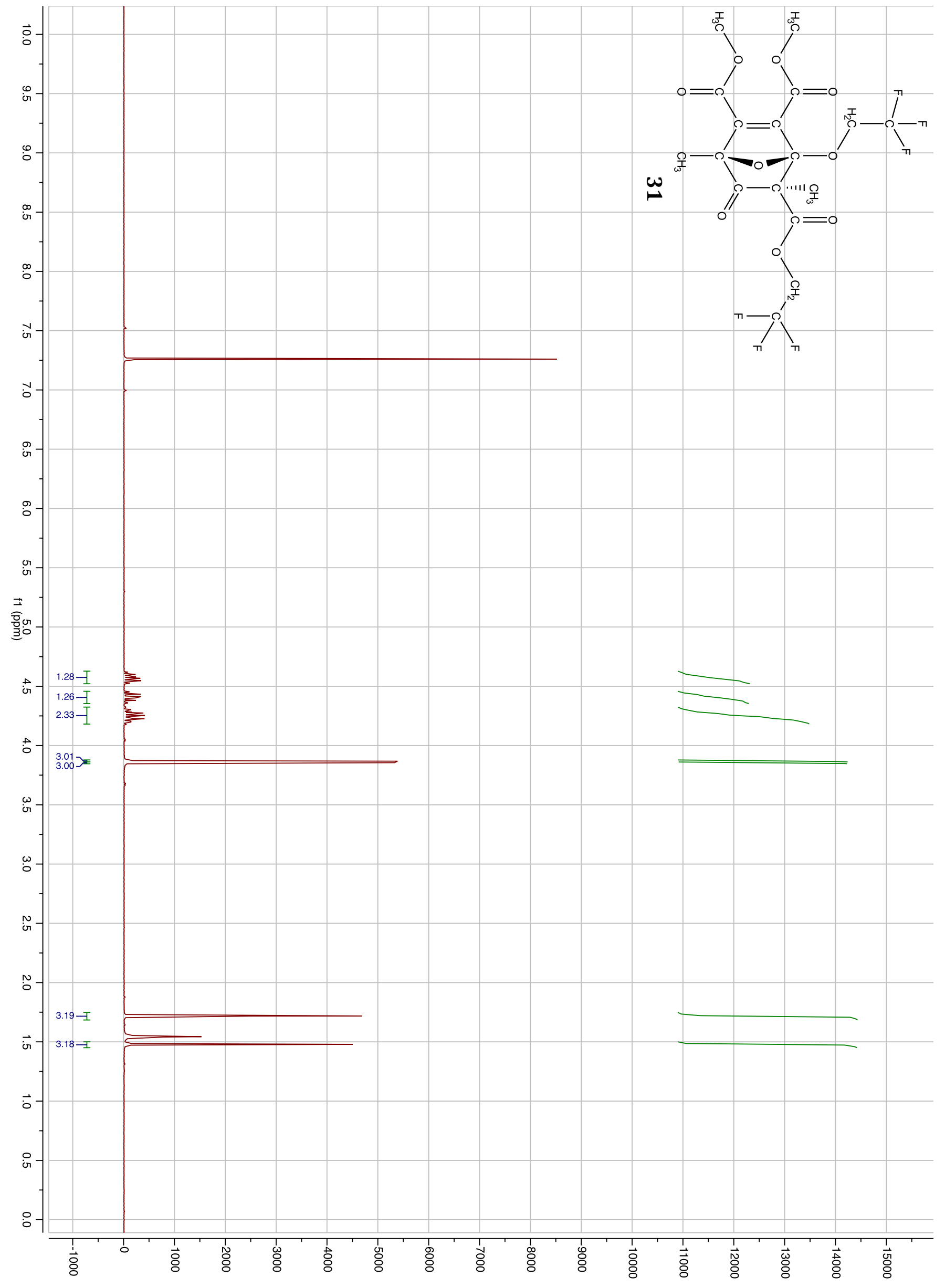




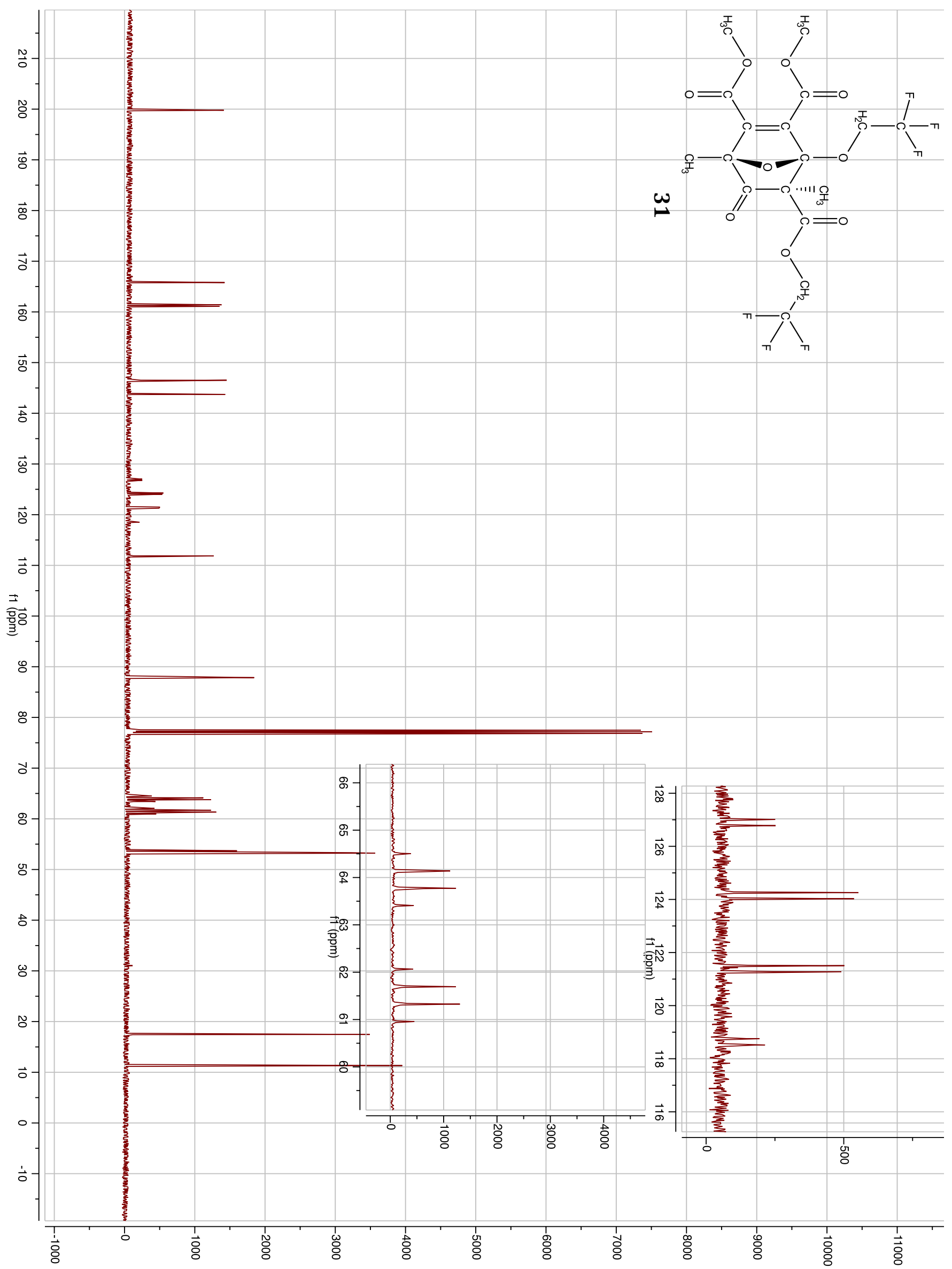




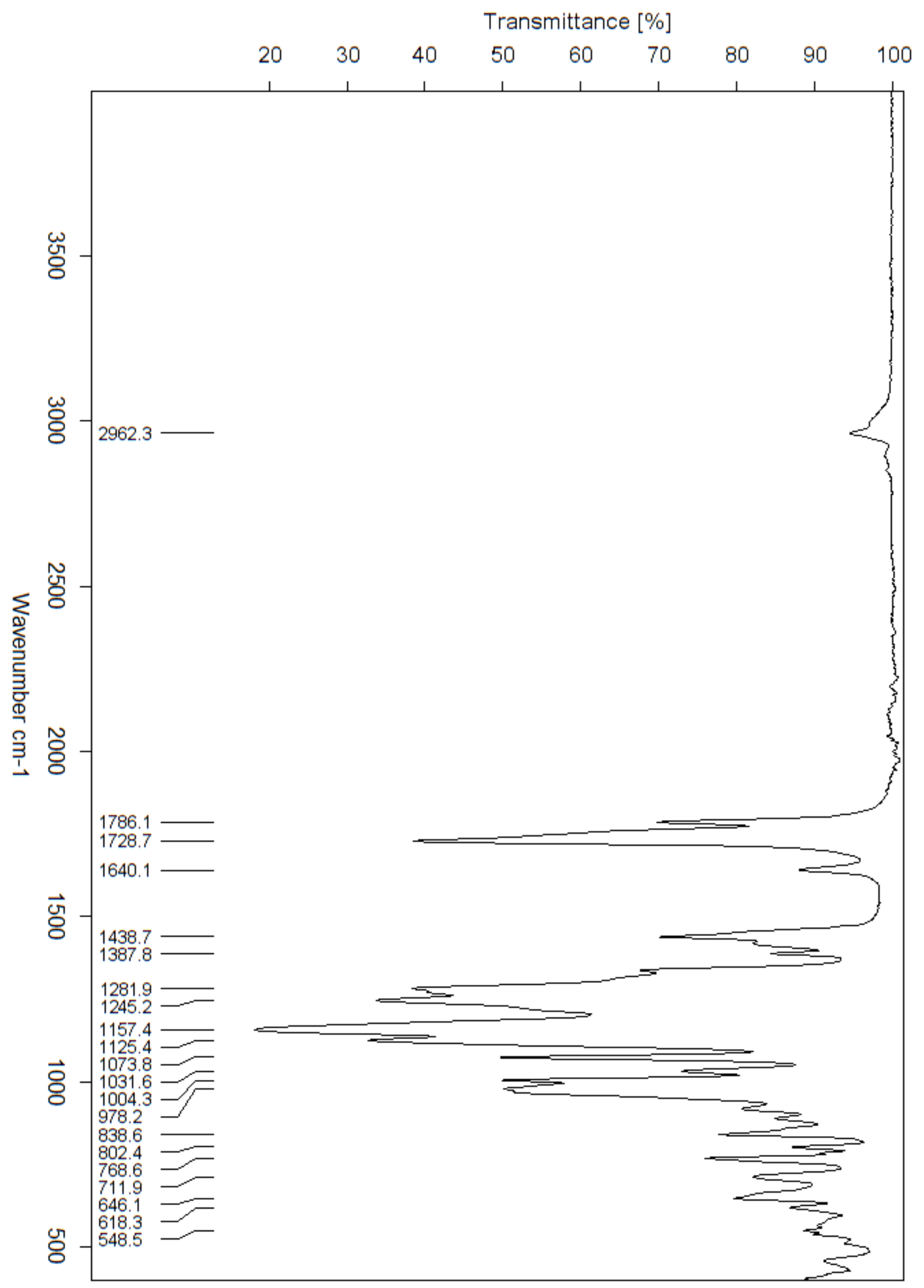




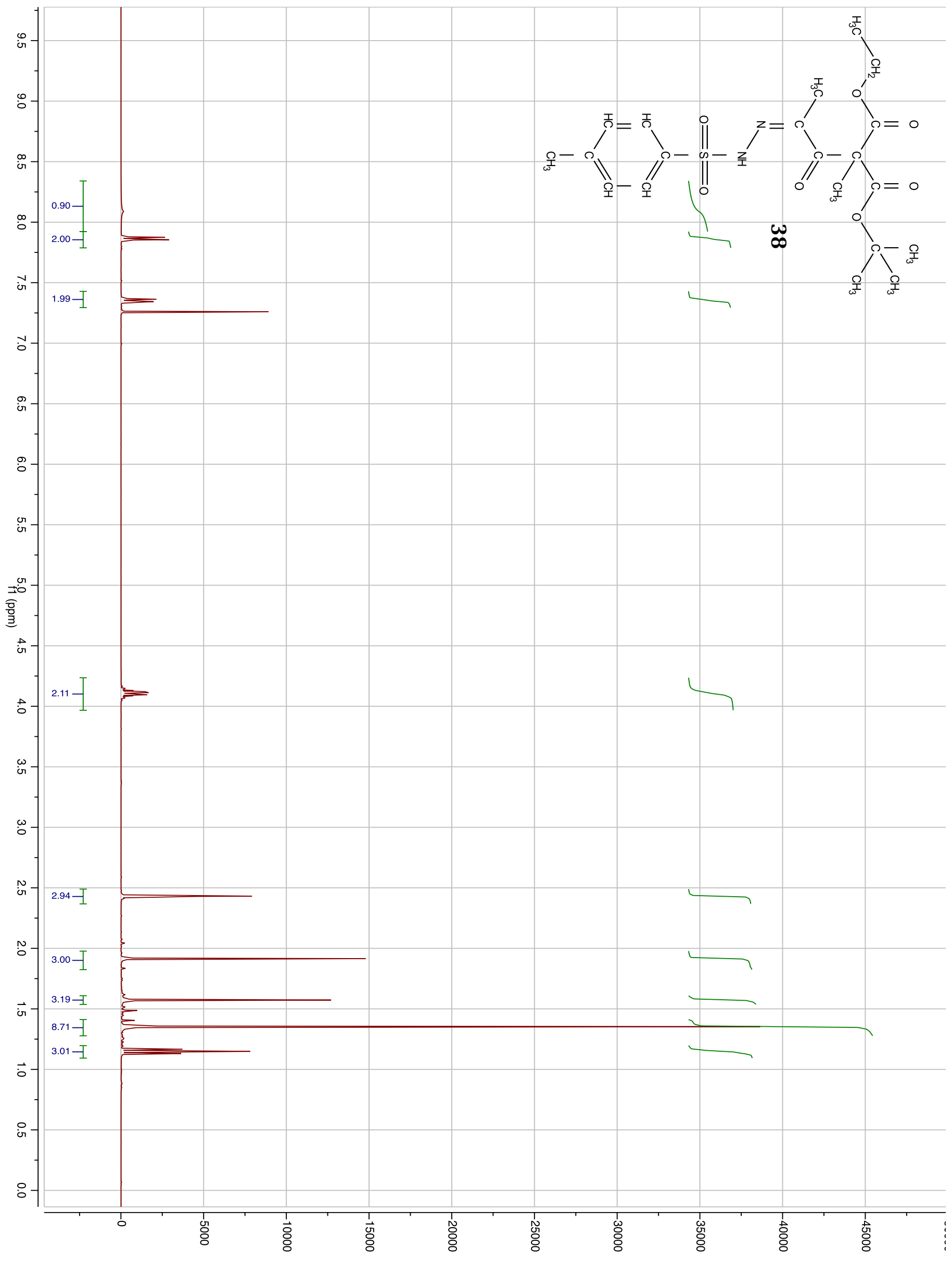




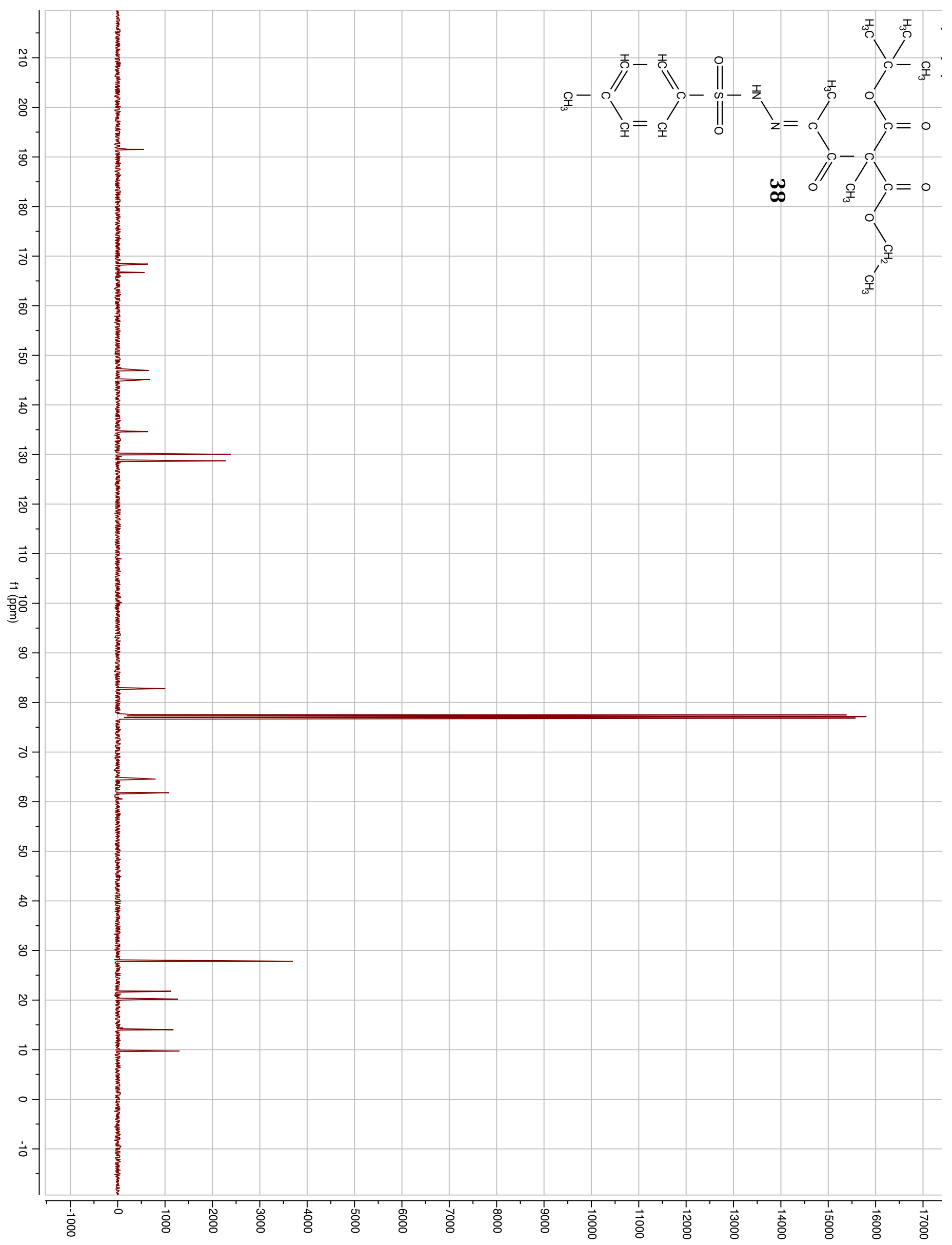




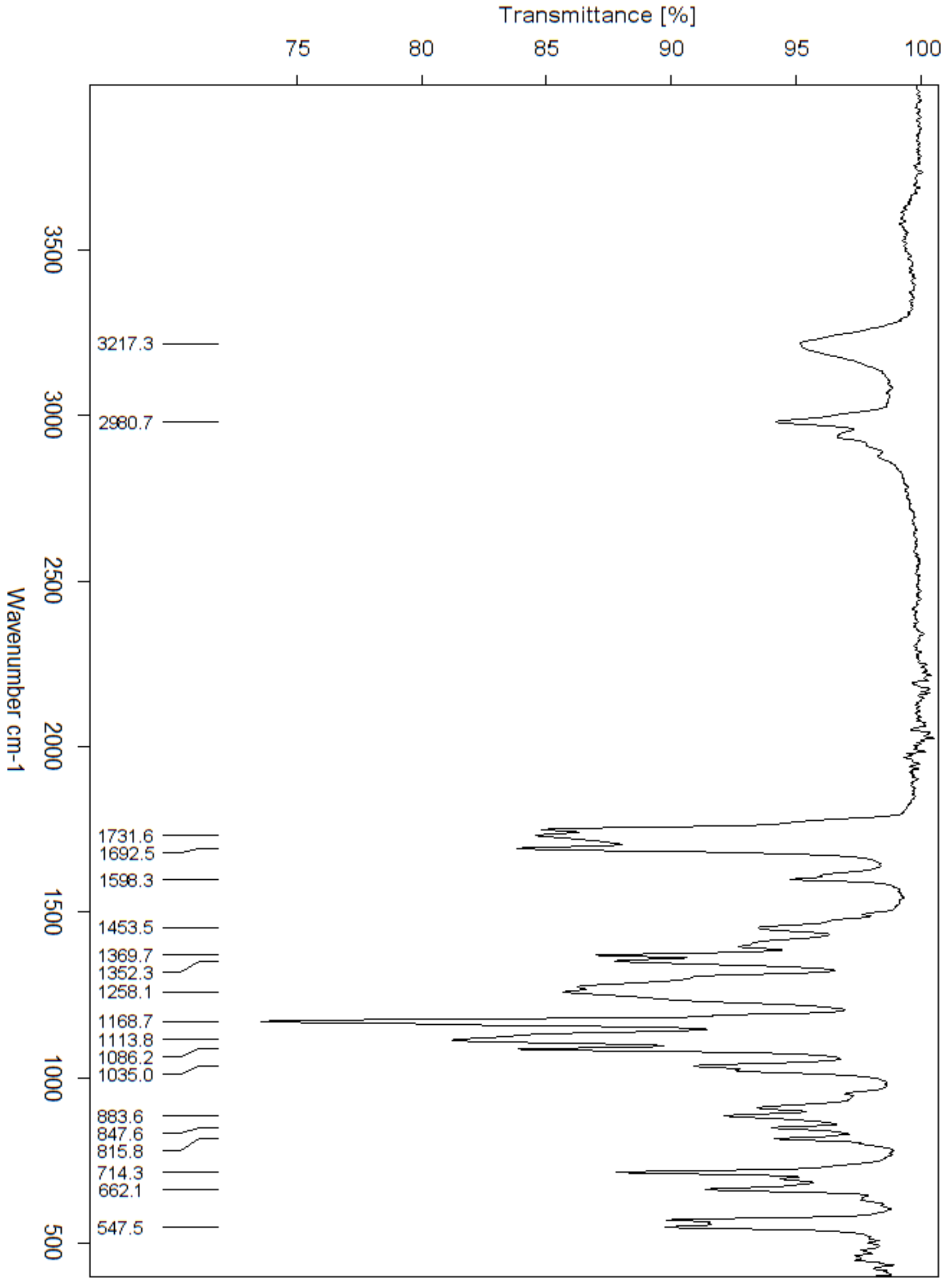




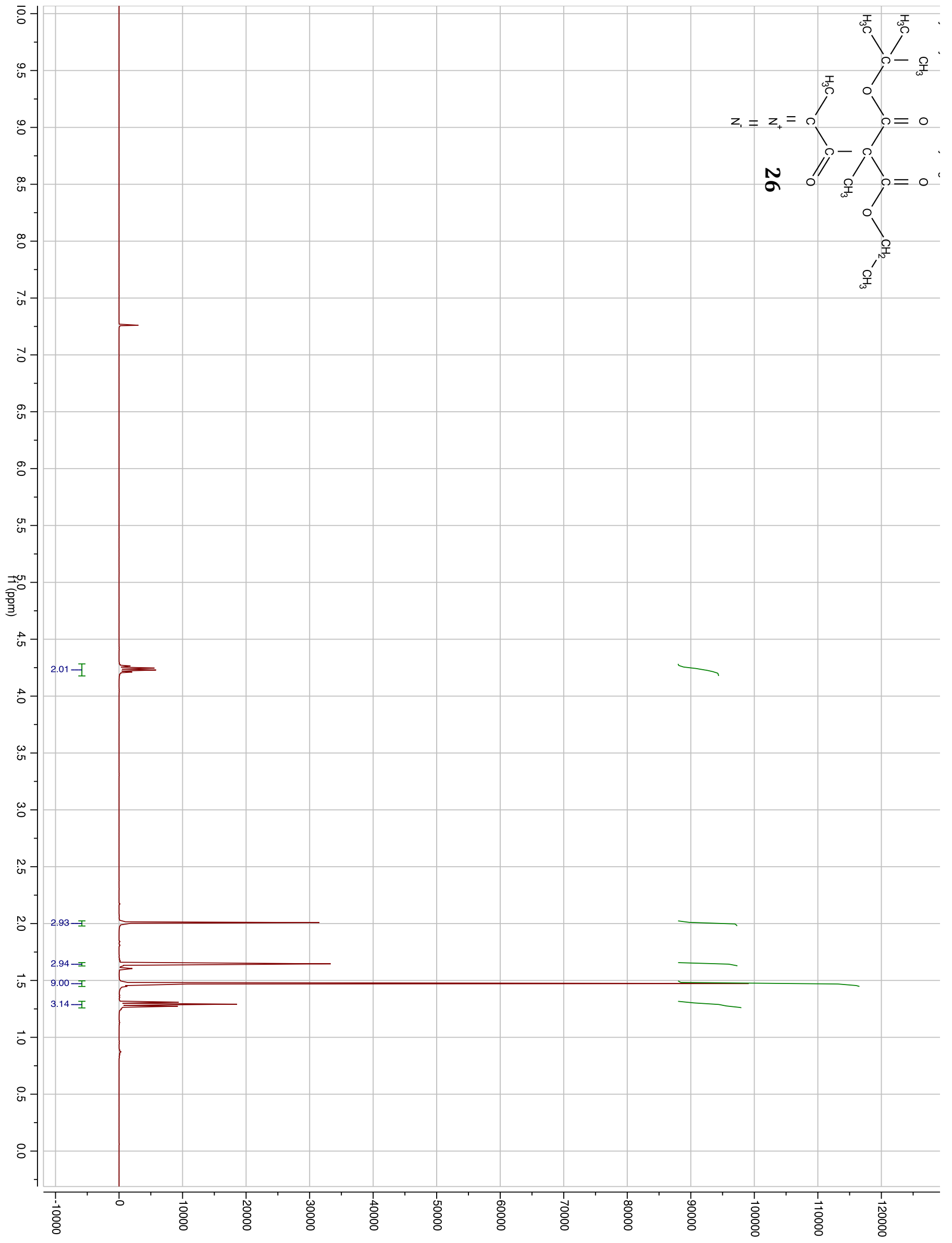




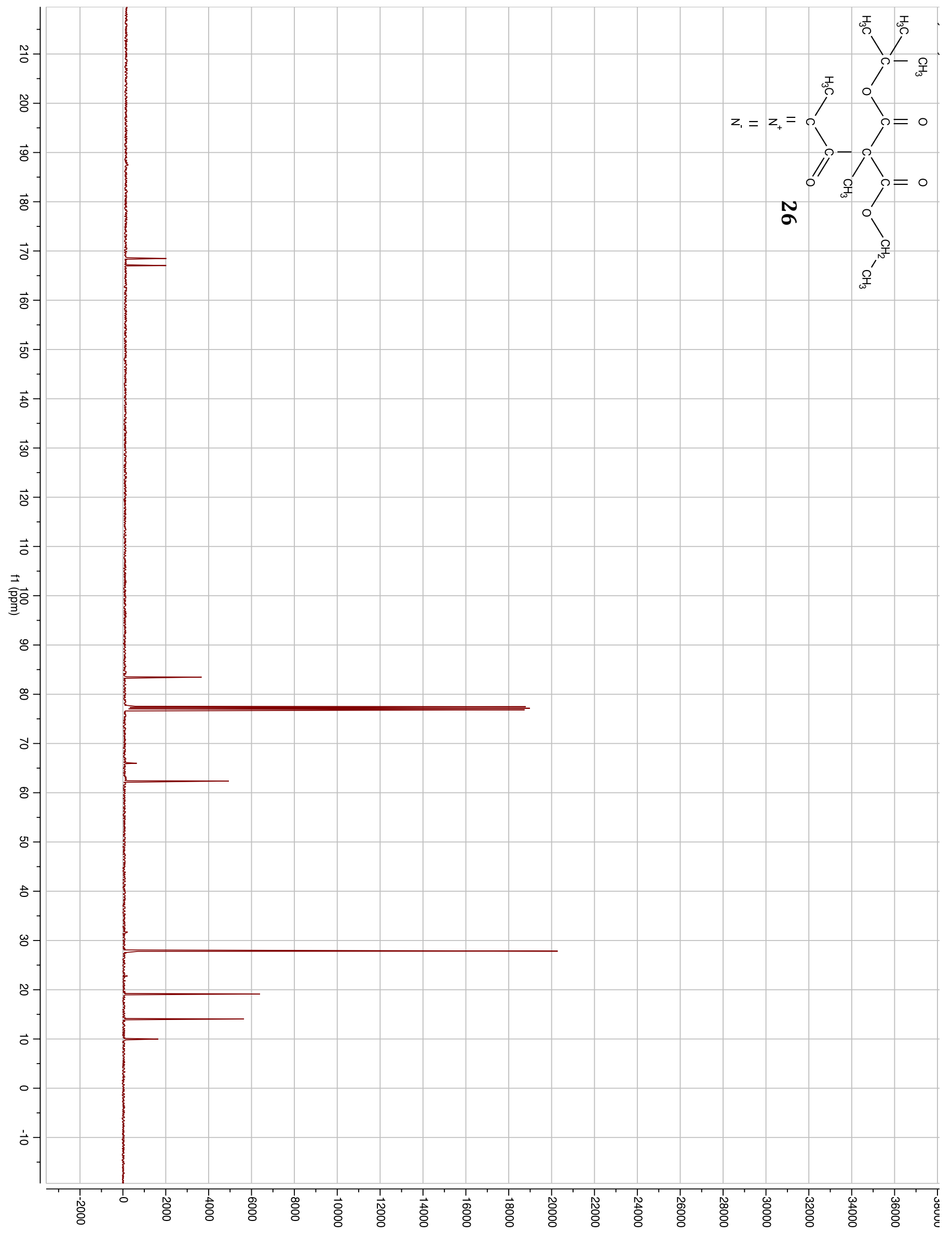




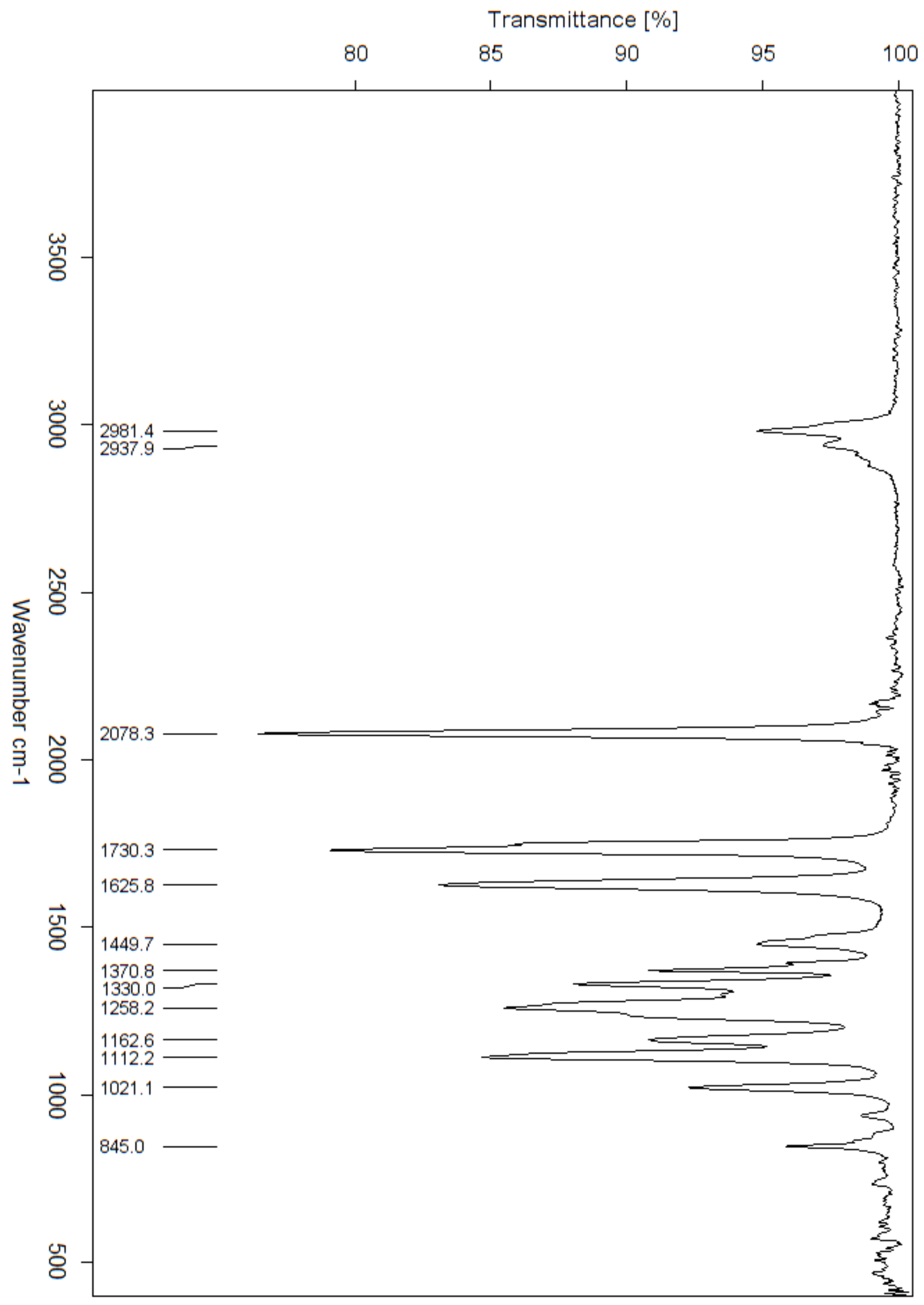




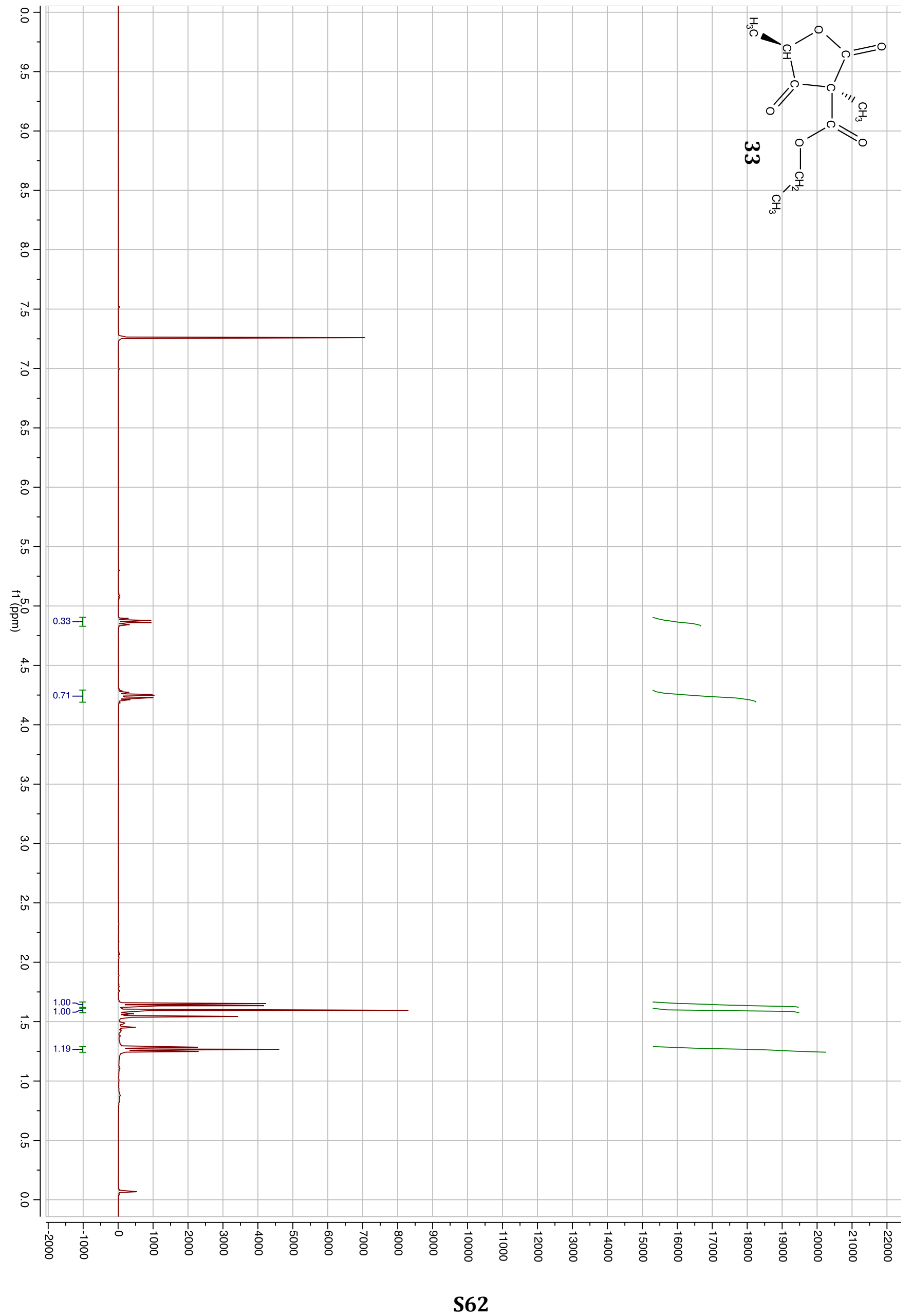




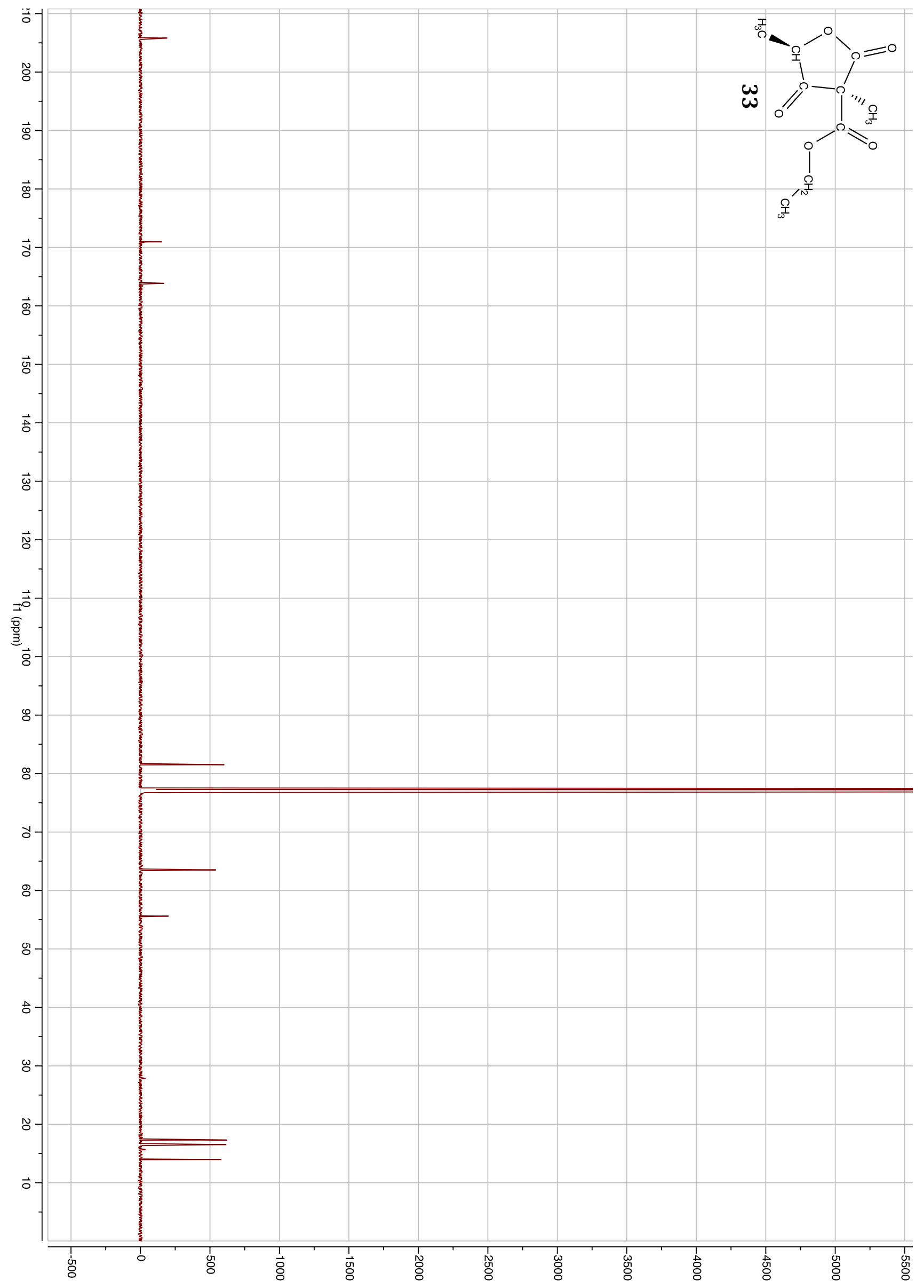




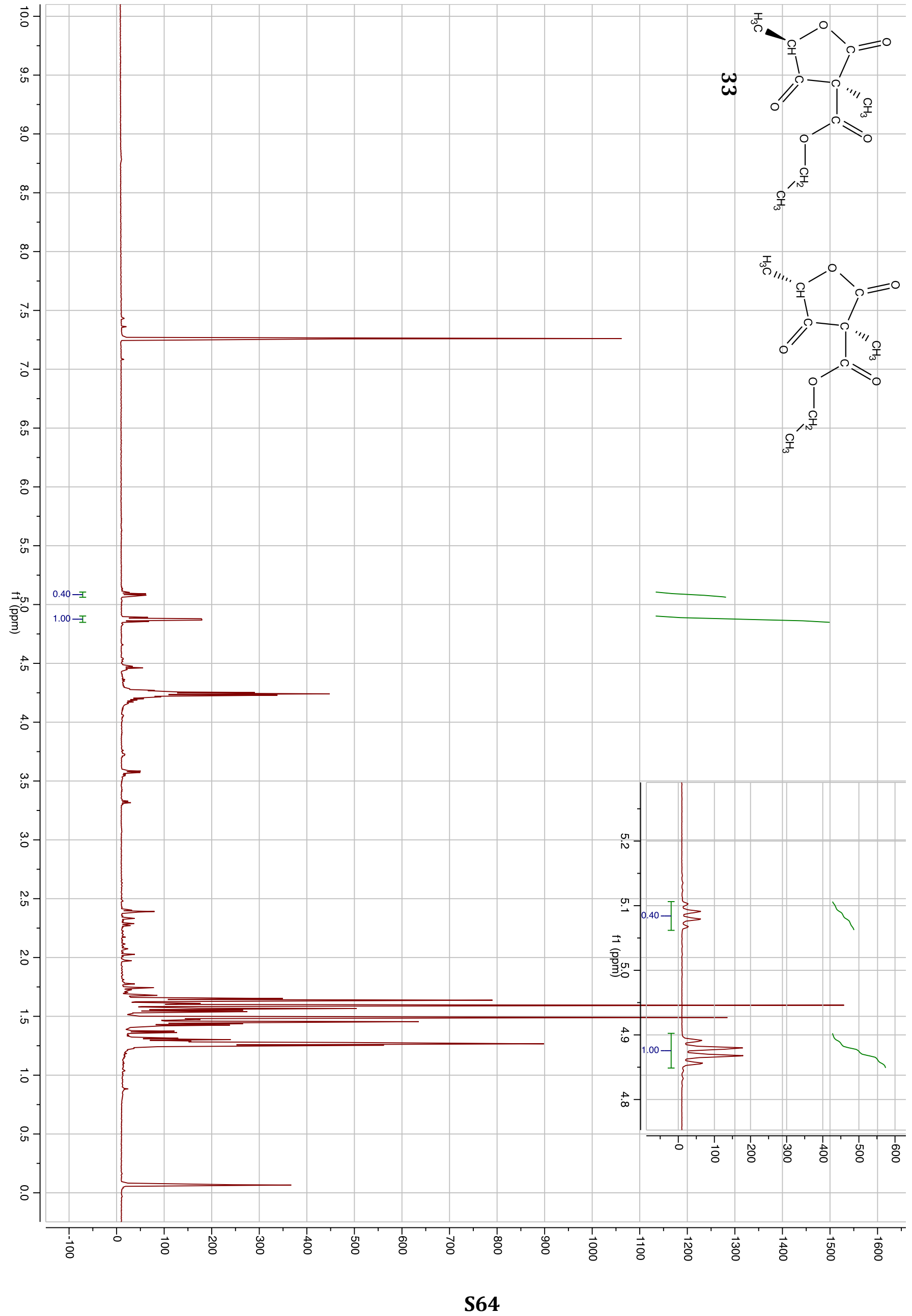




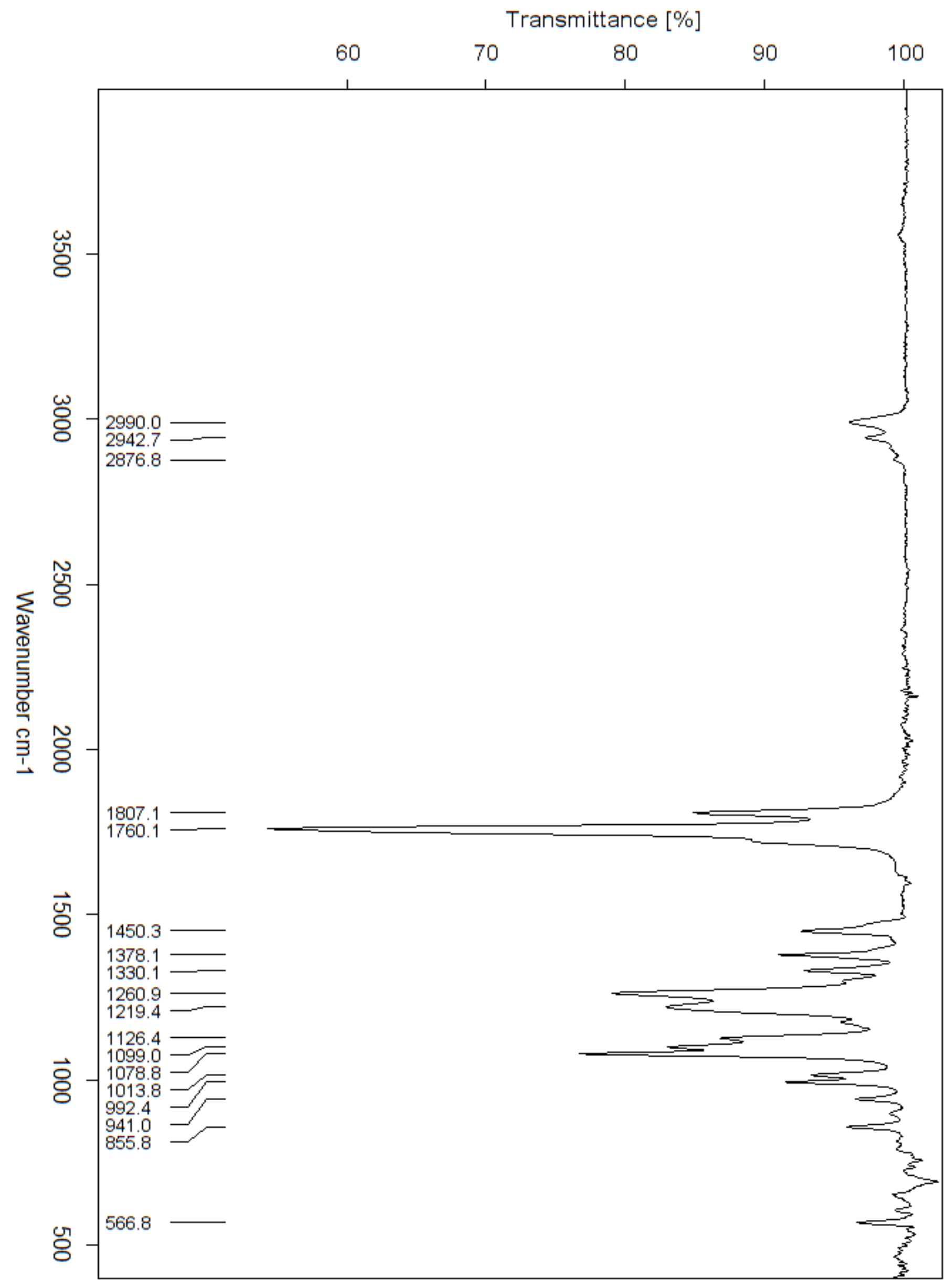




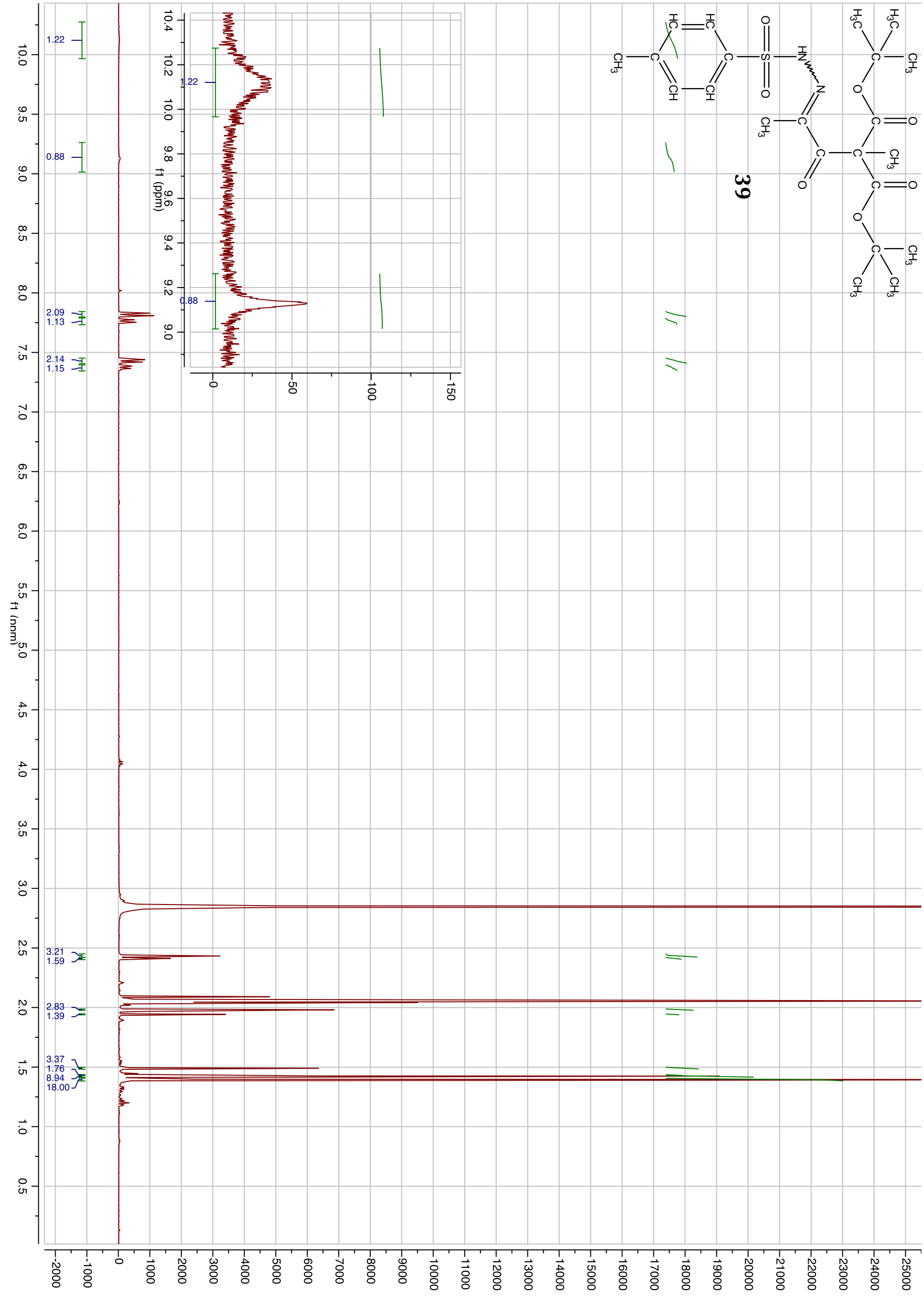




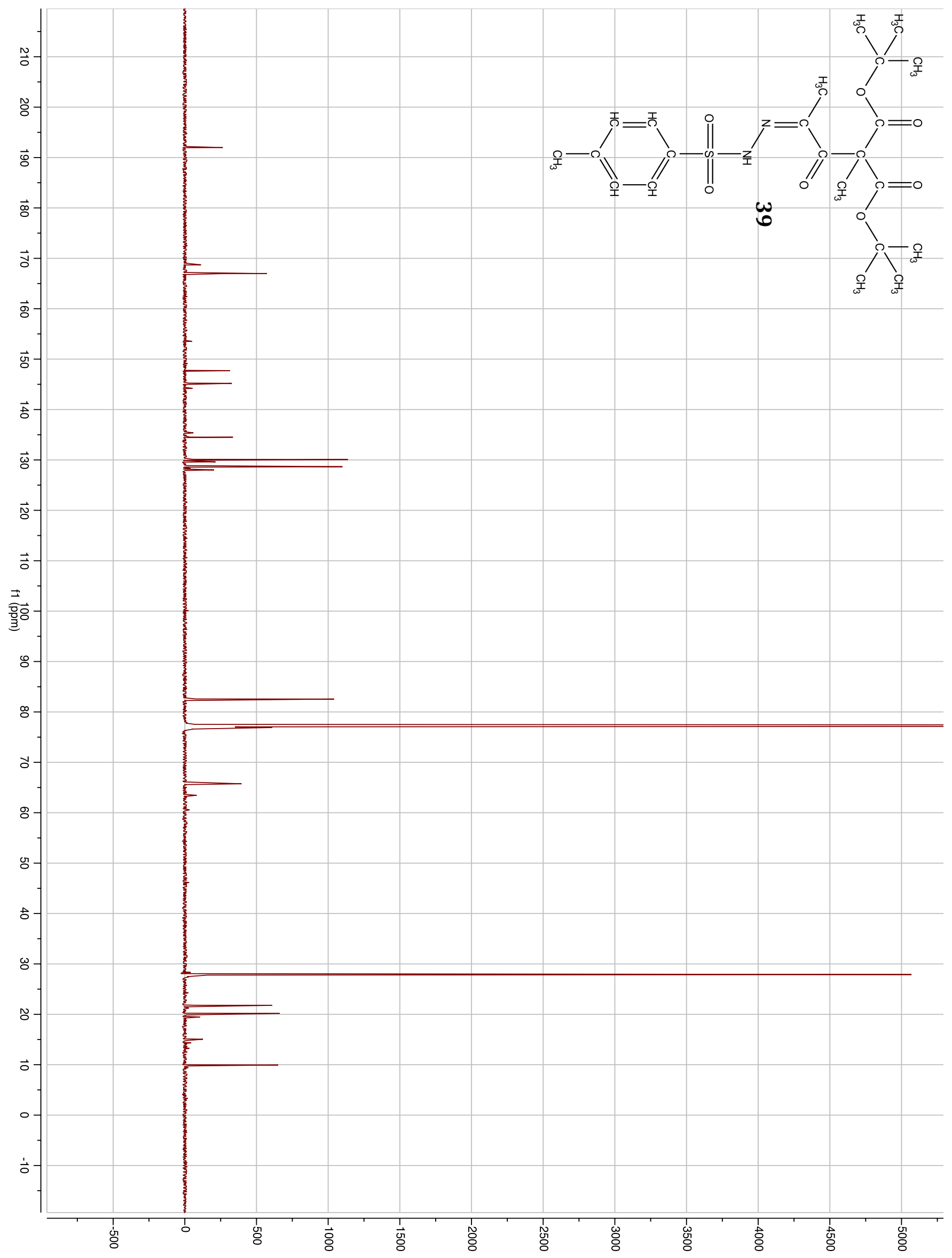




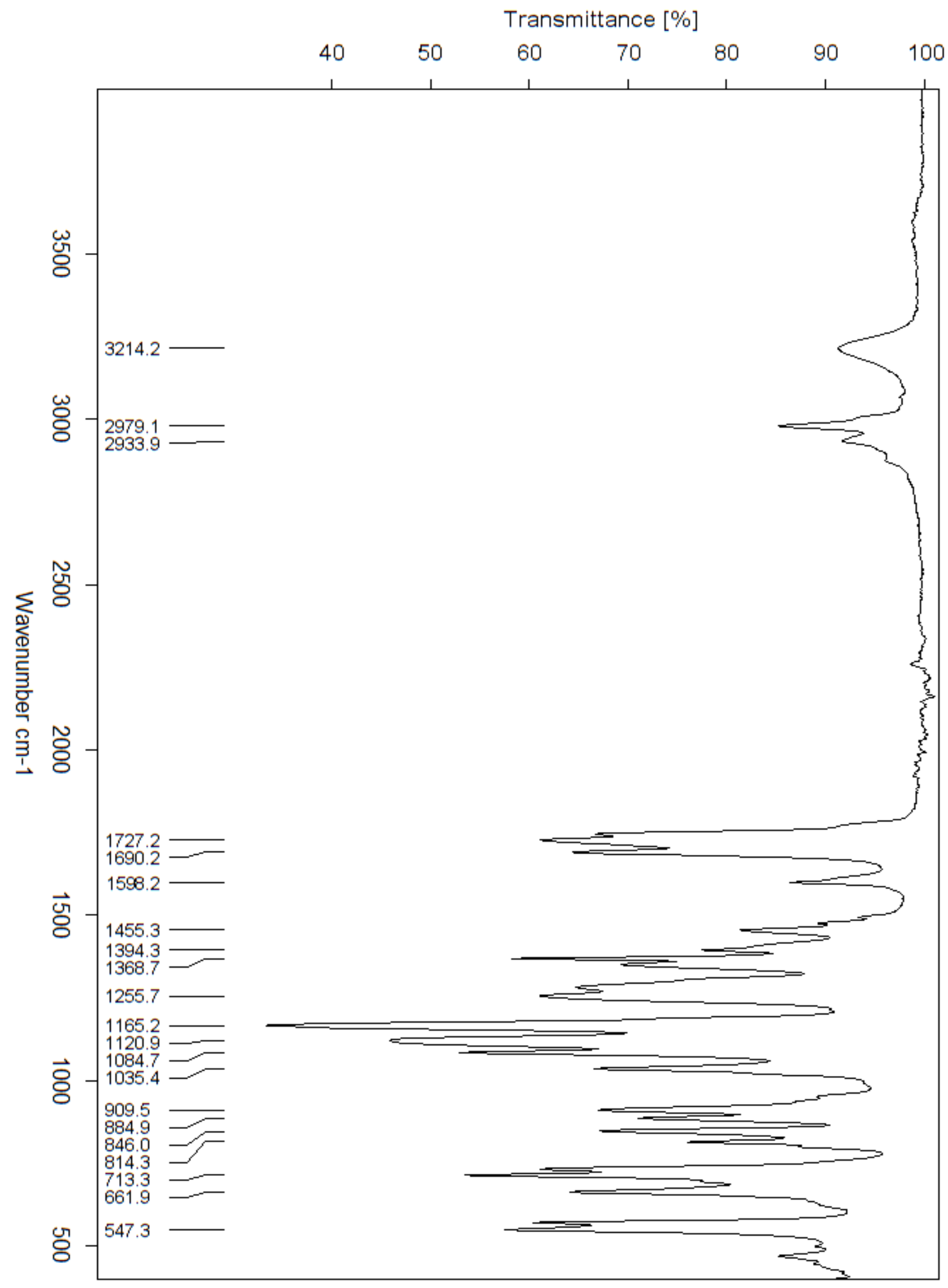




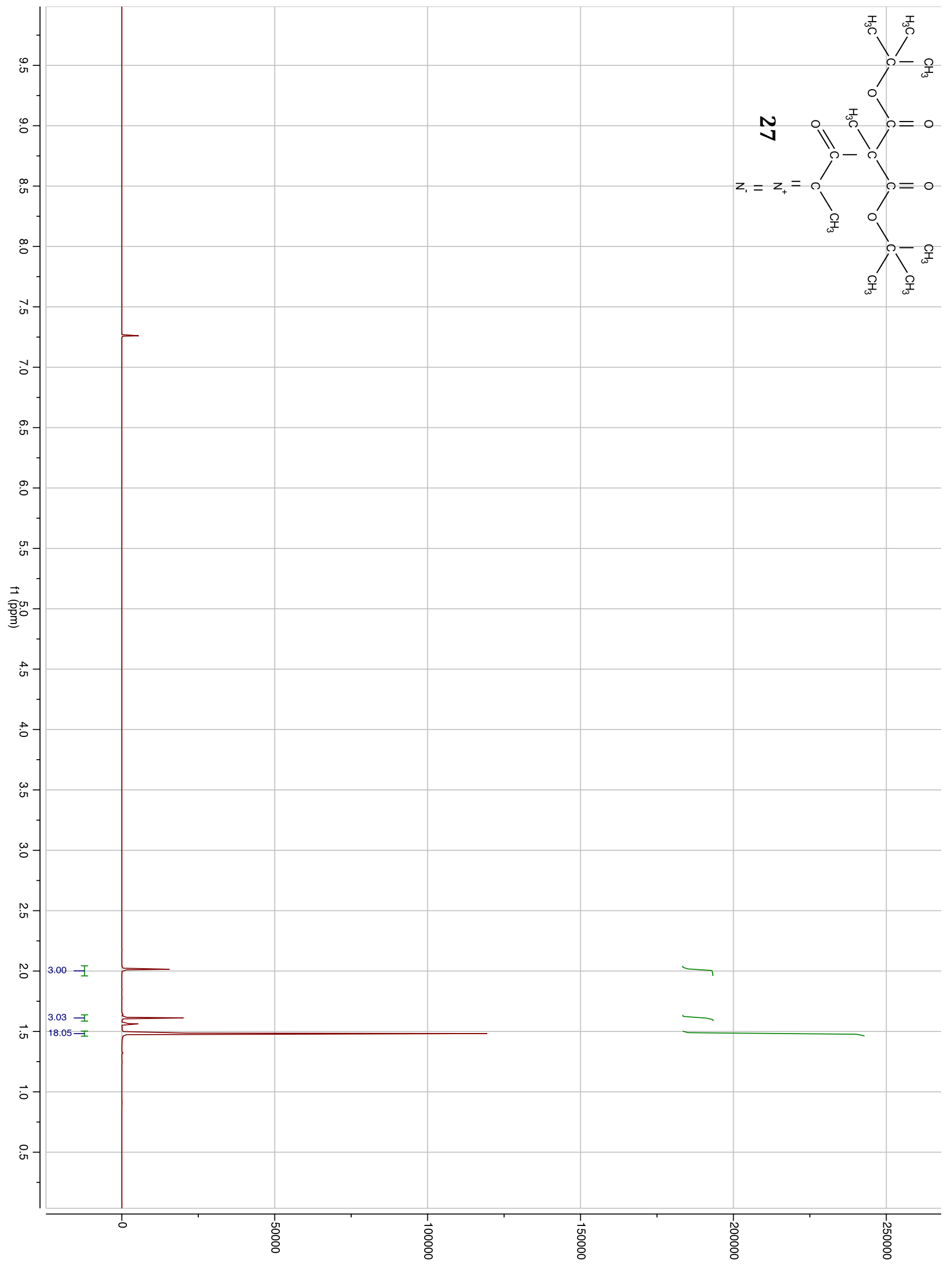




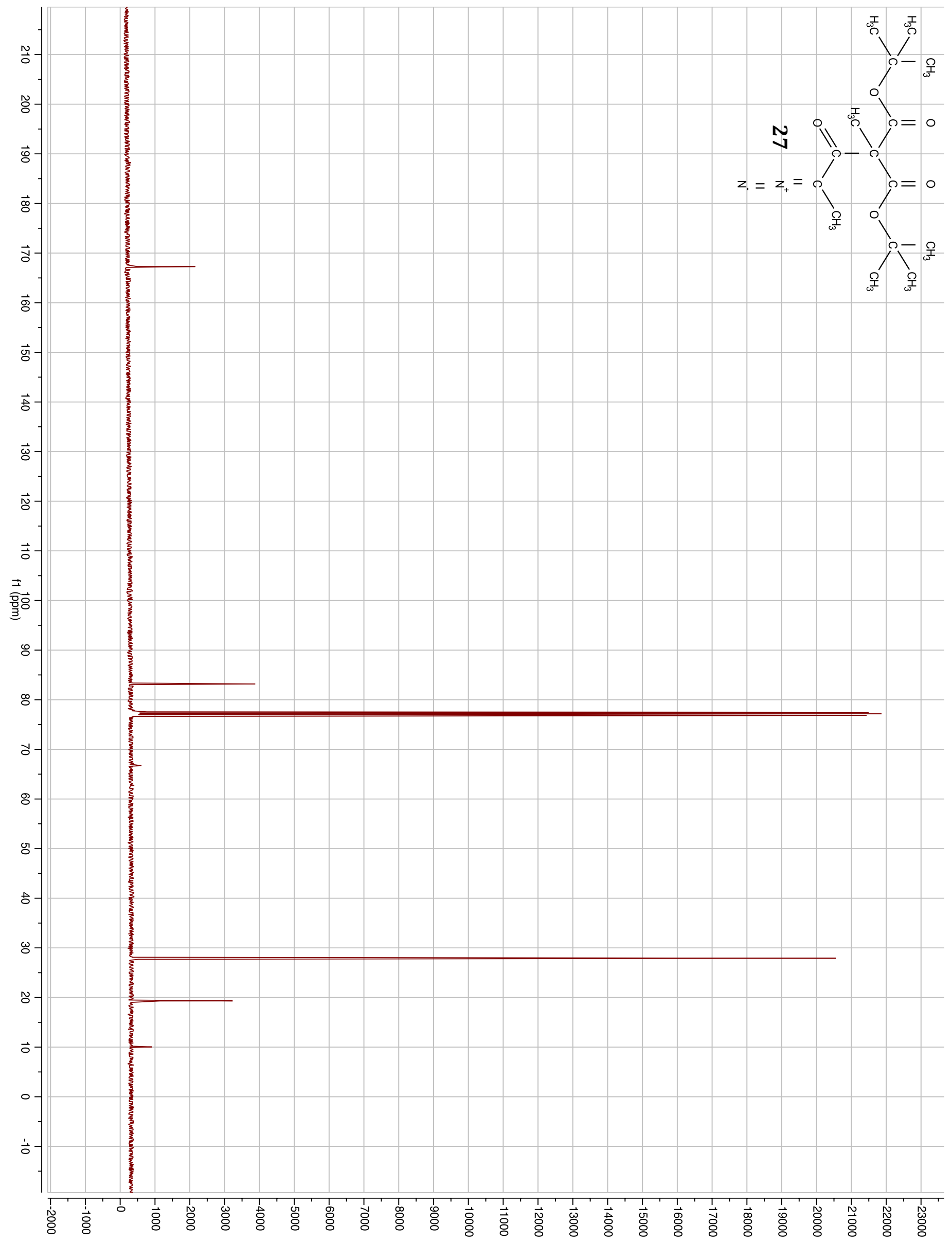




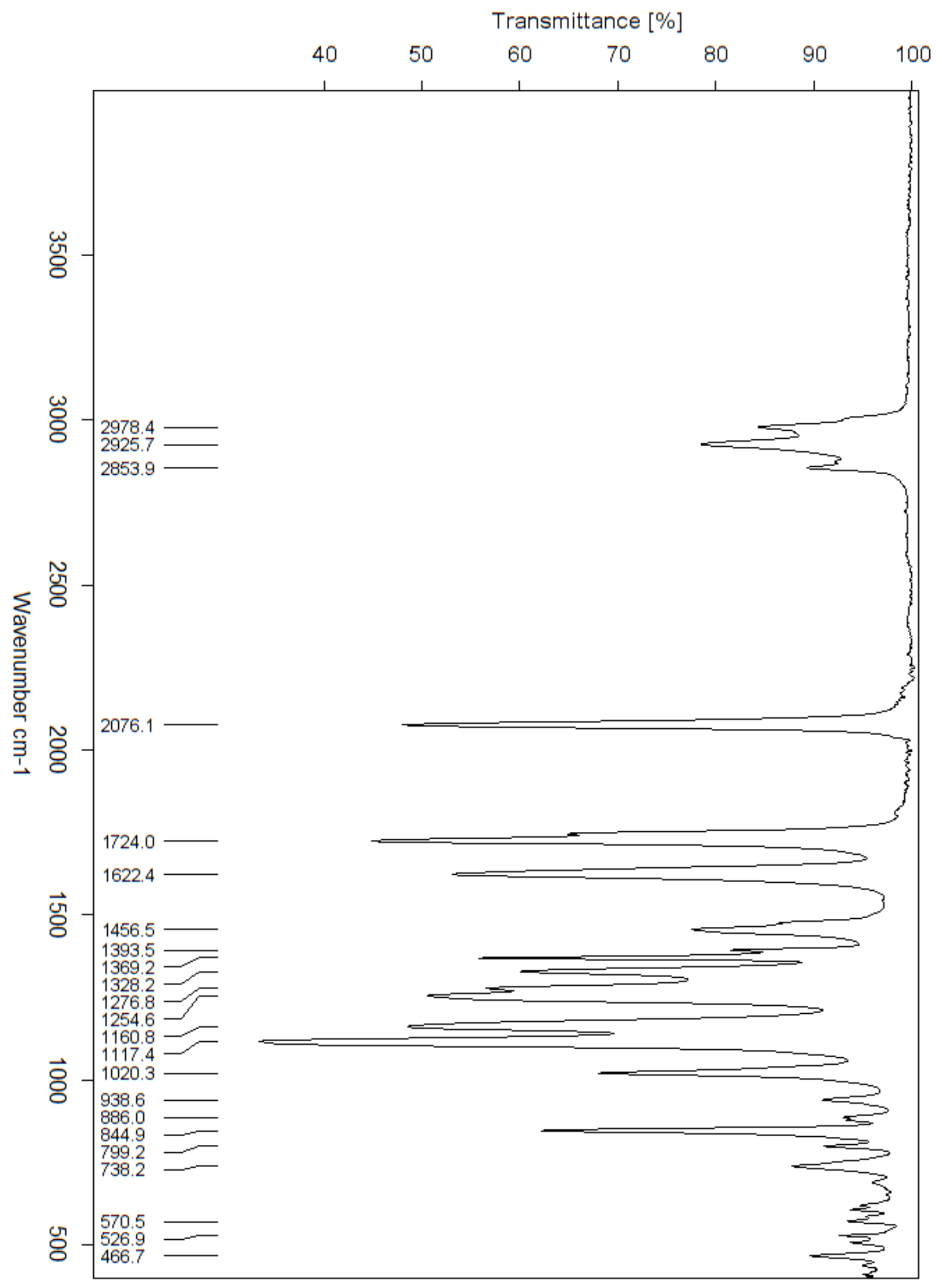




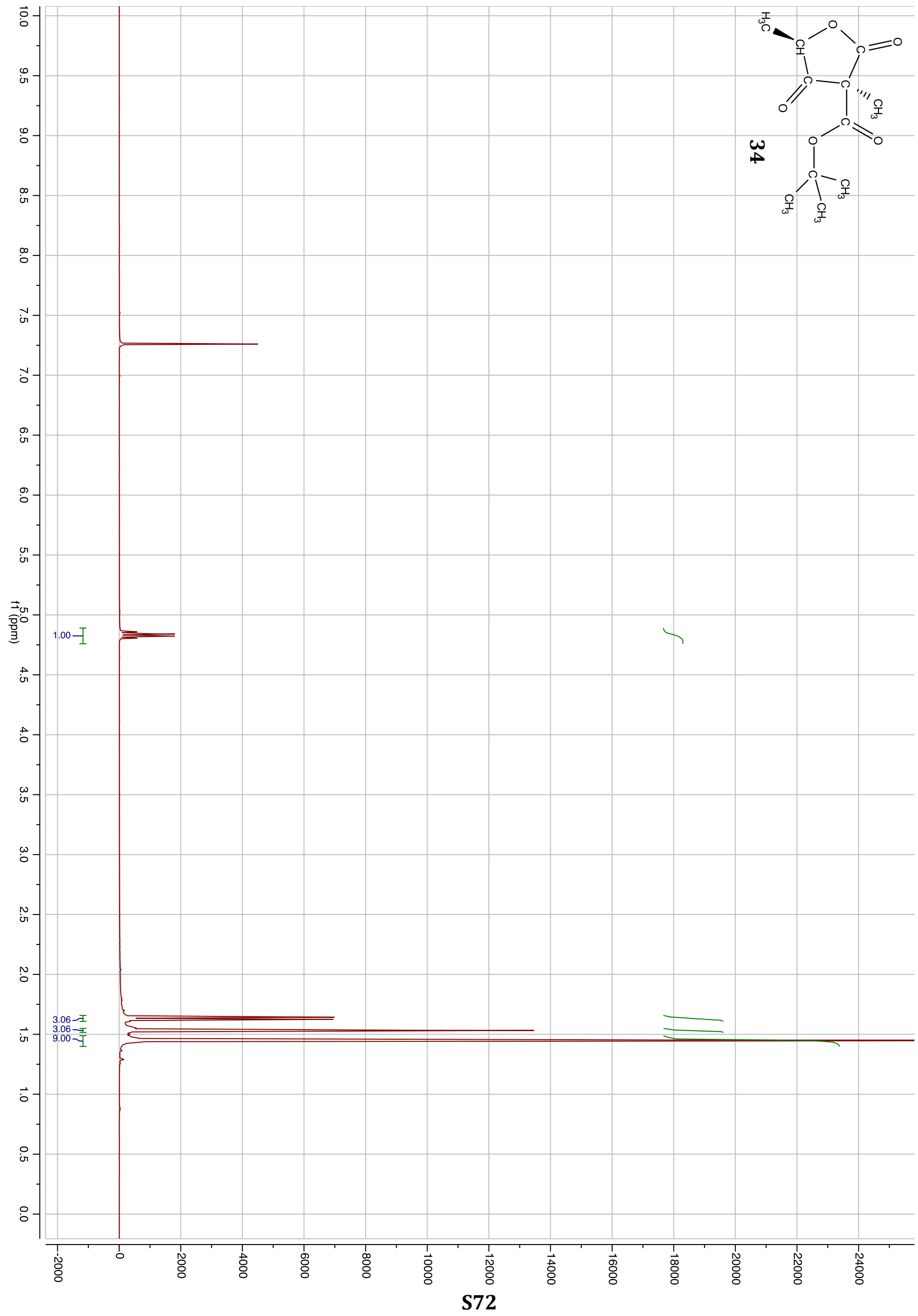




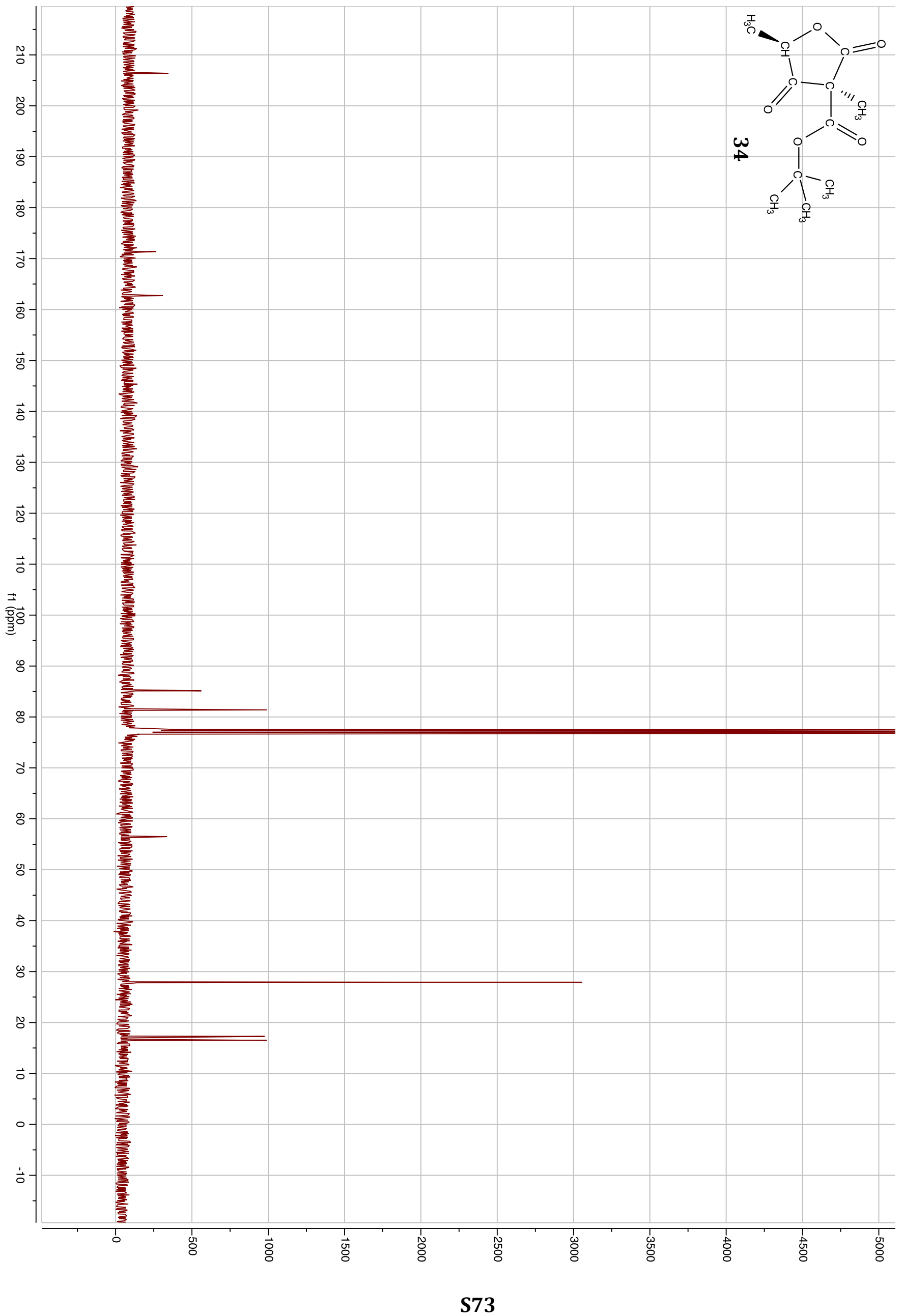




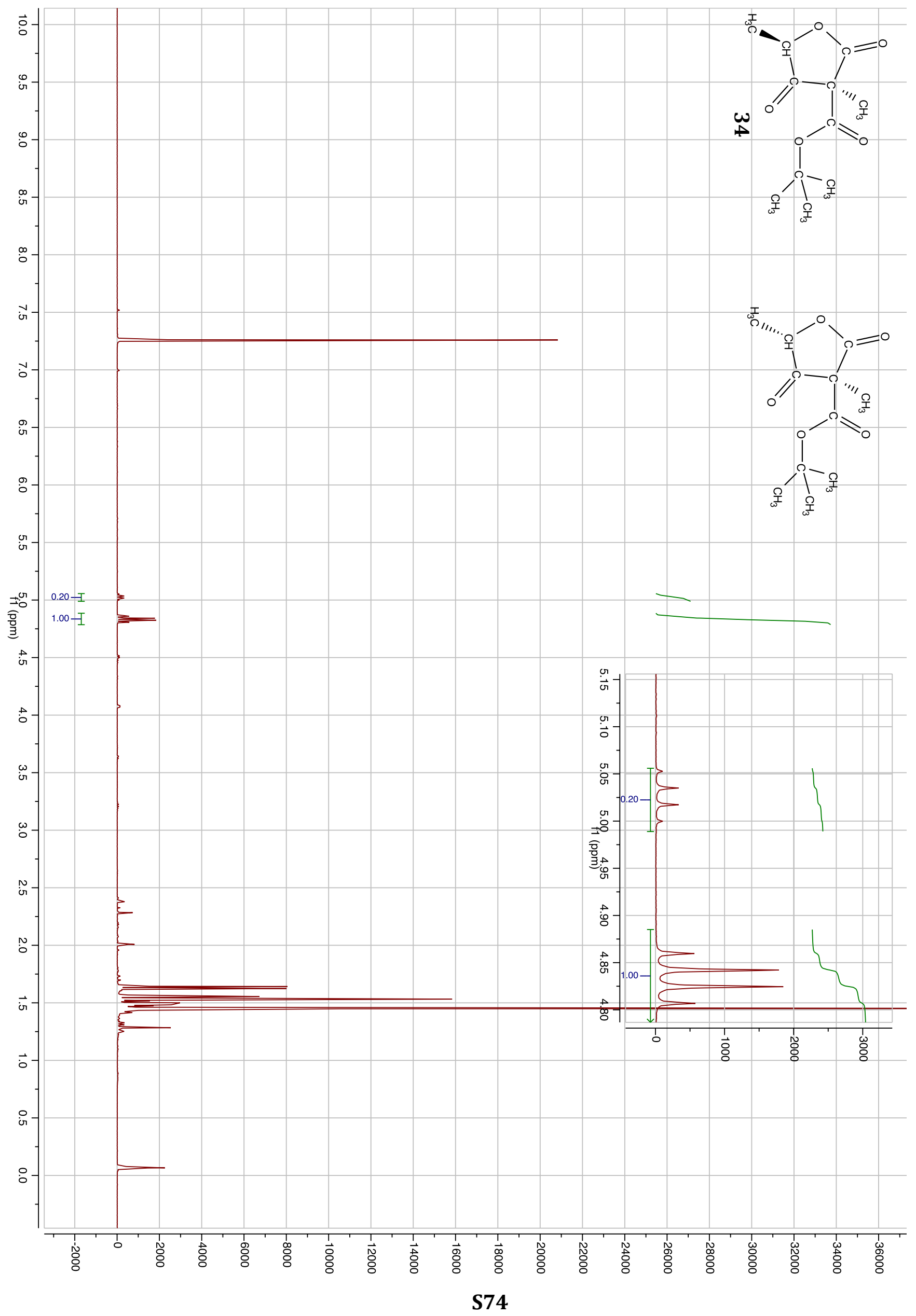


Transmittance [\%]

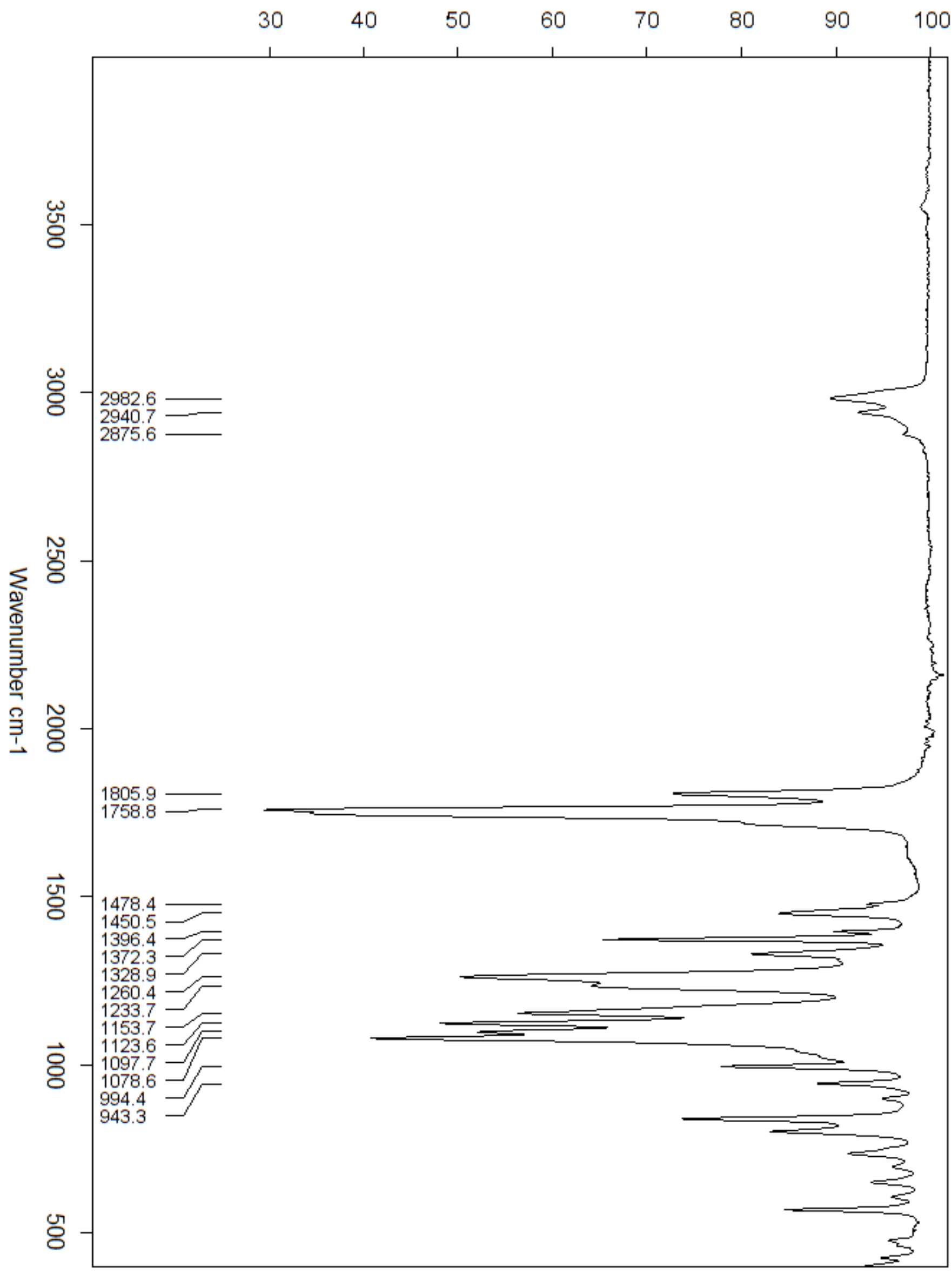




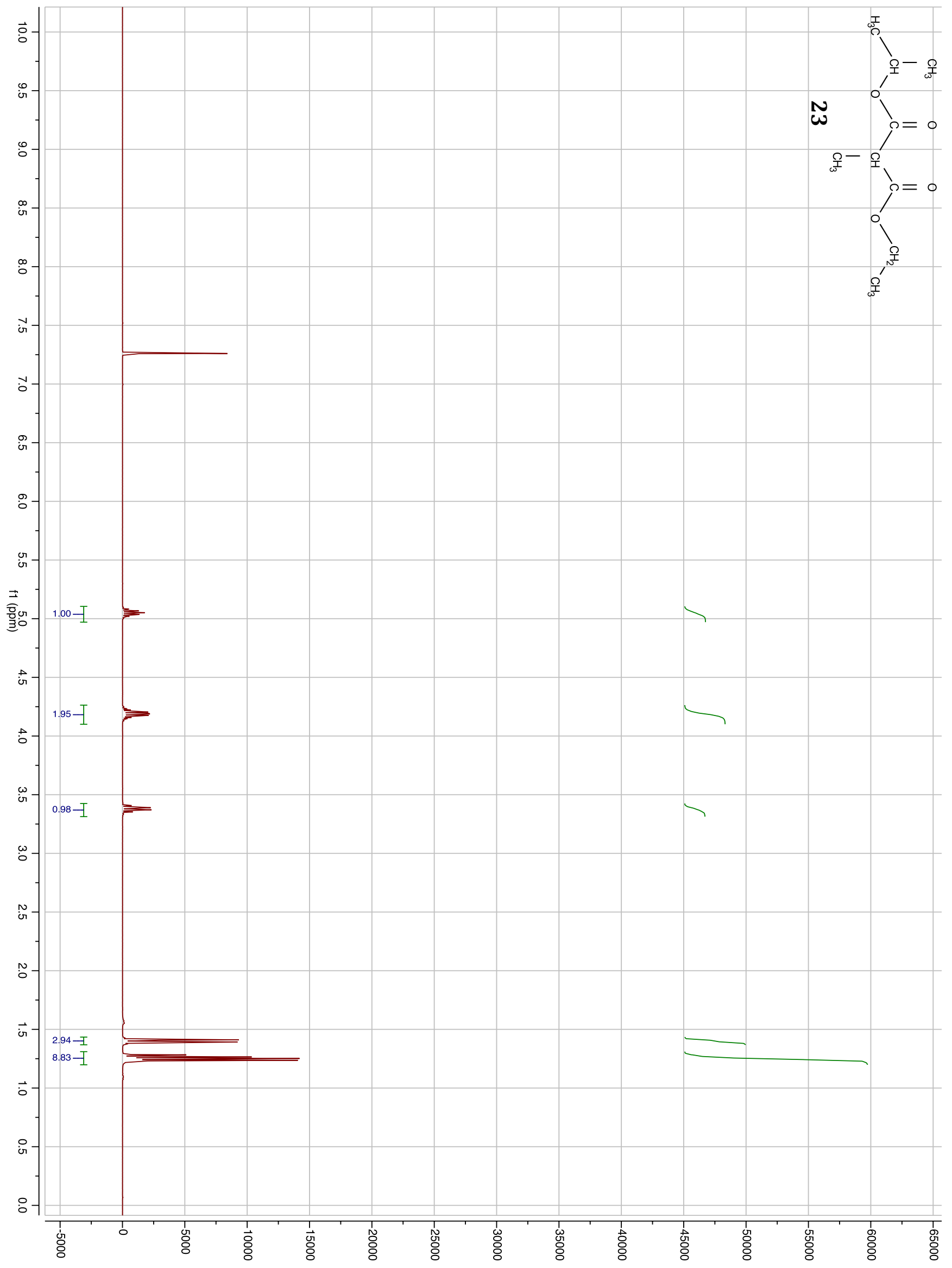




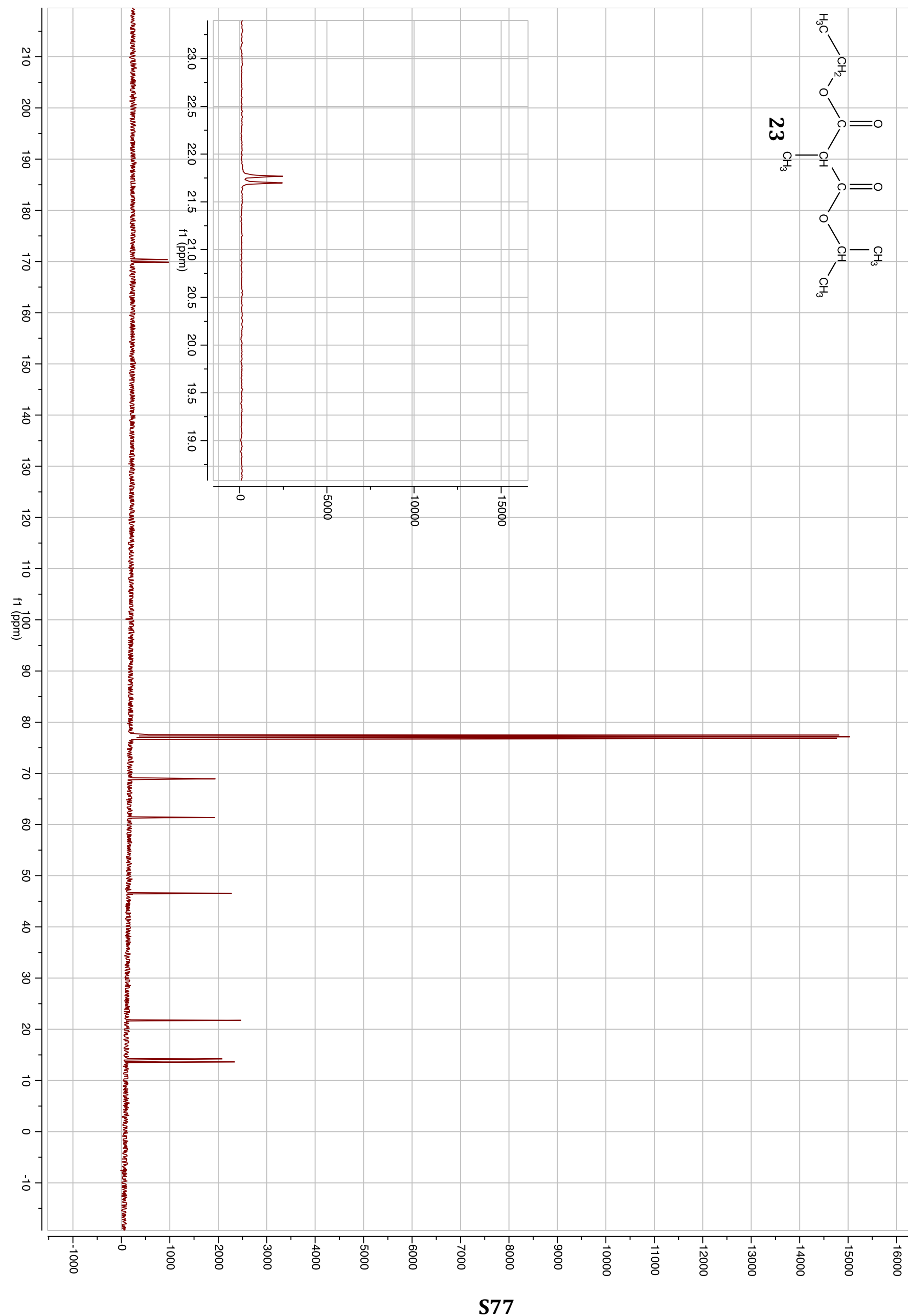




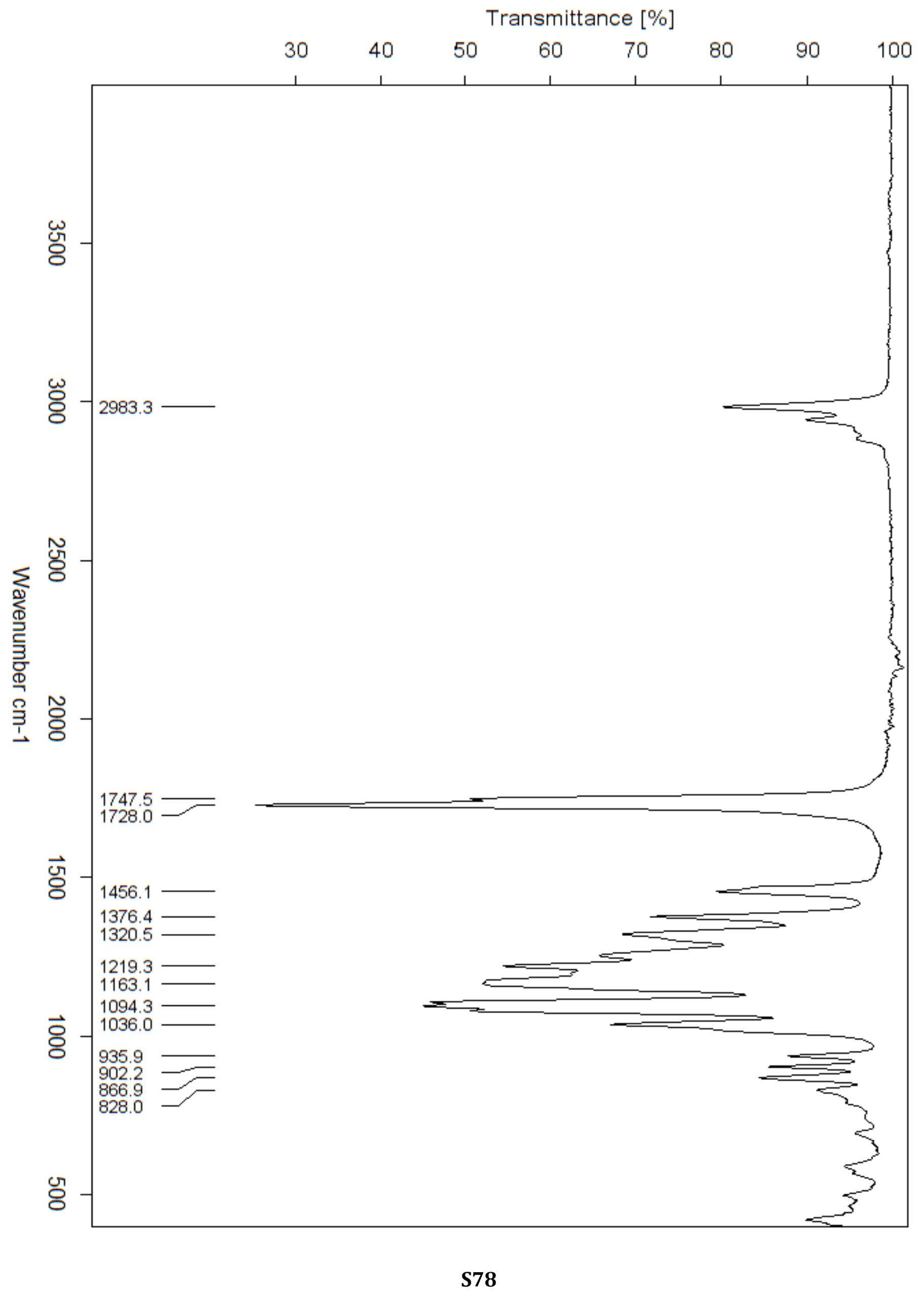




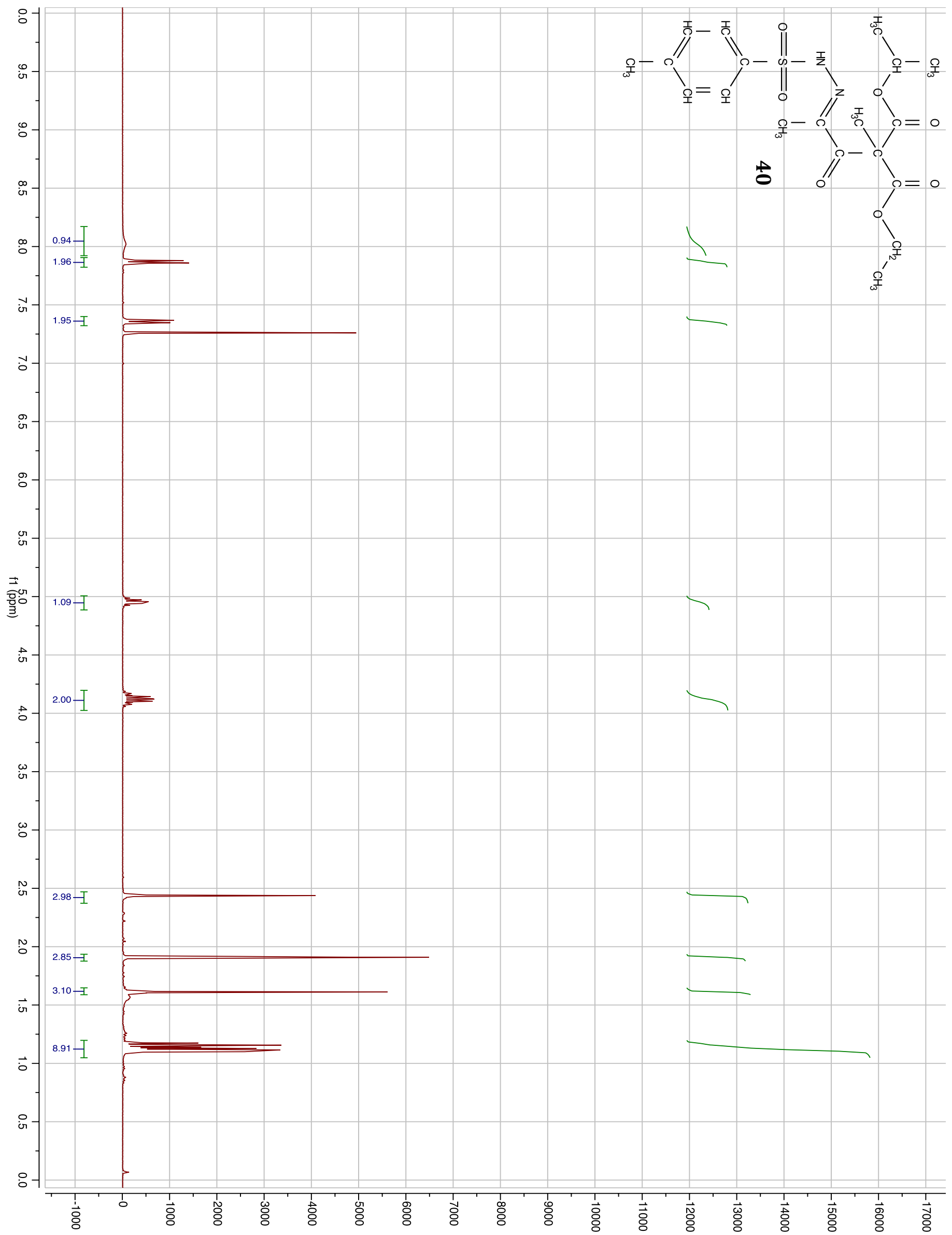




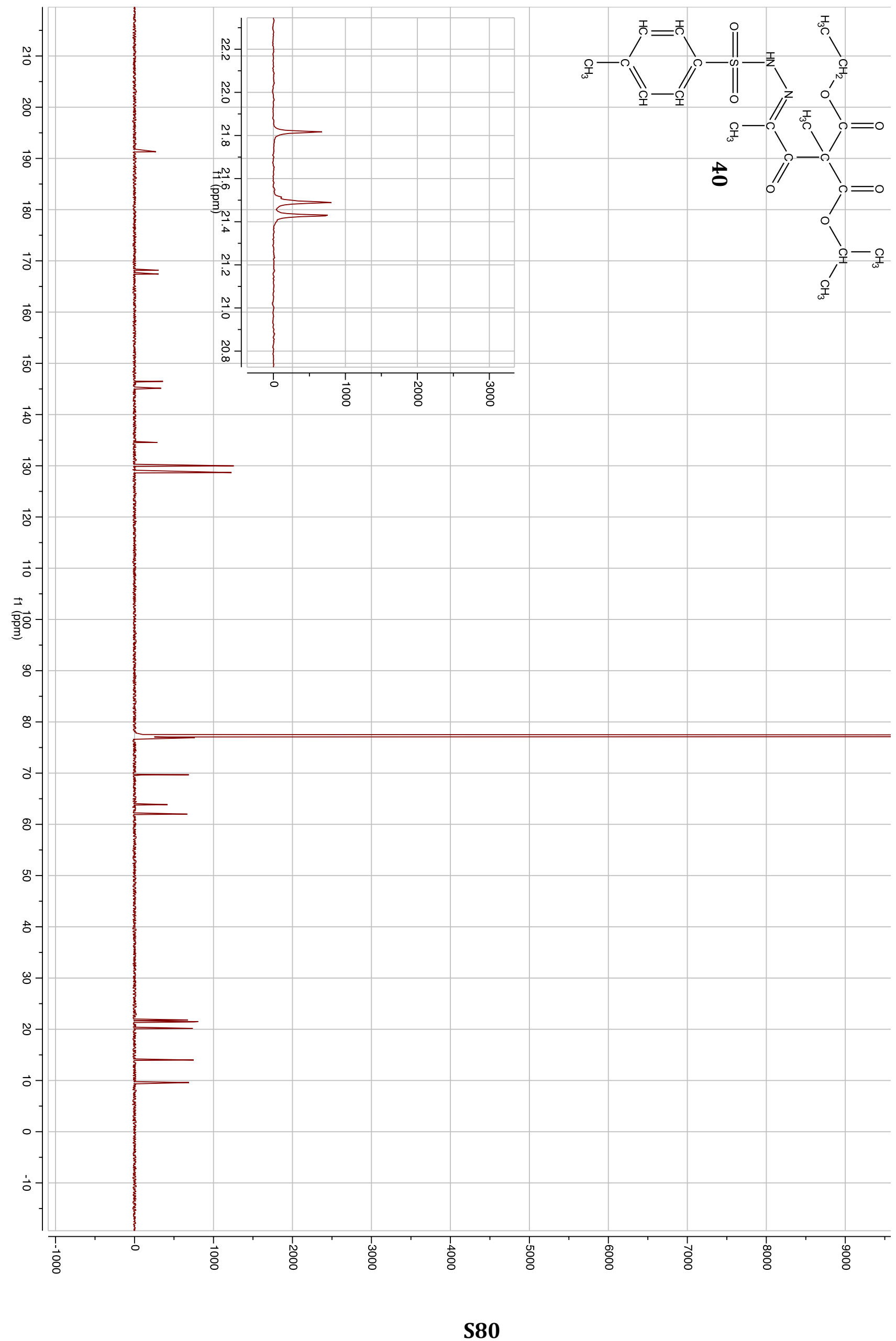




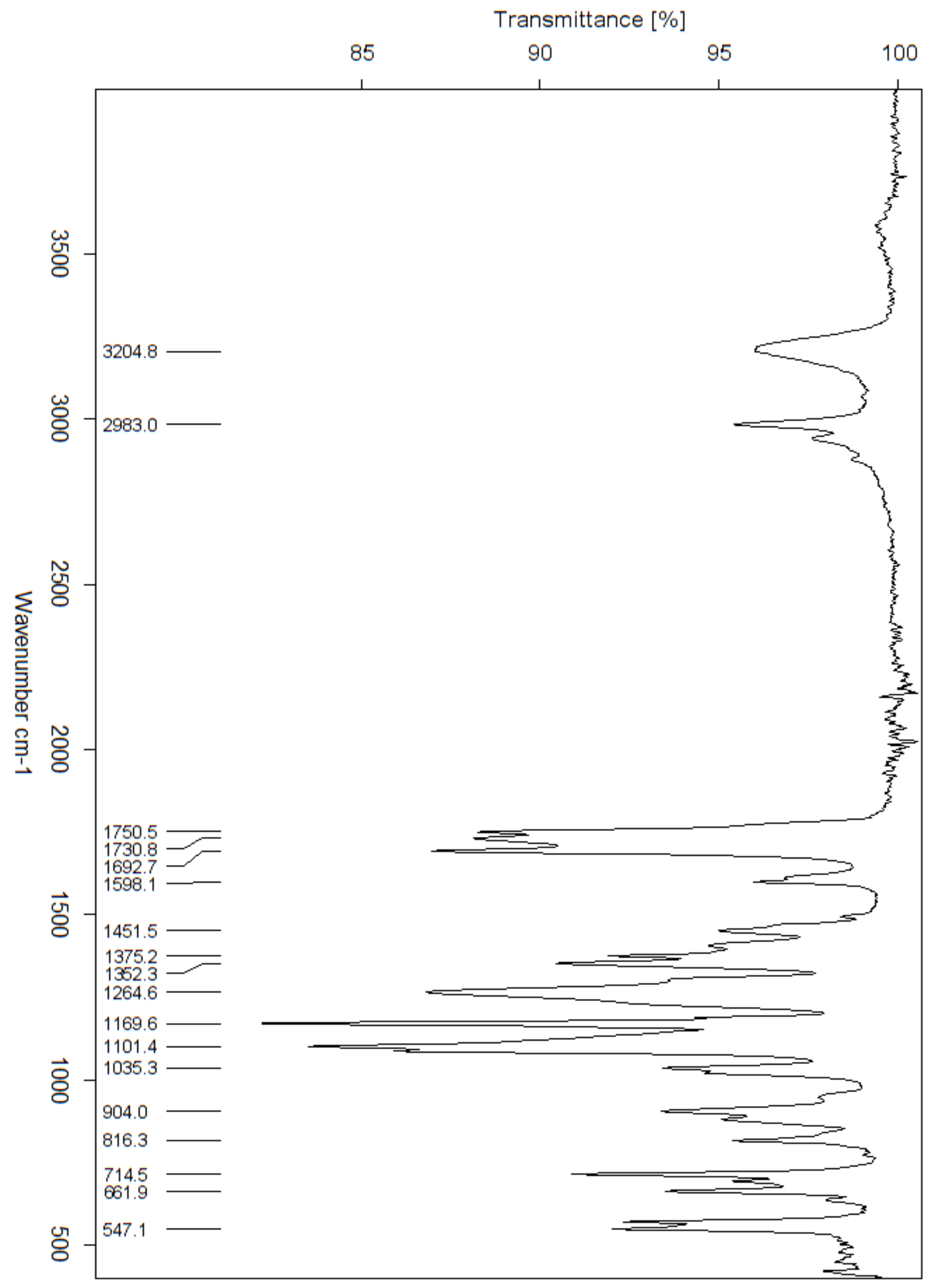




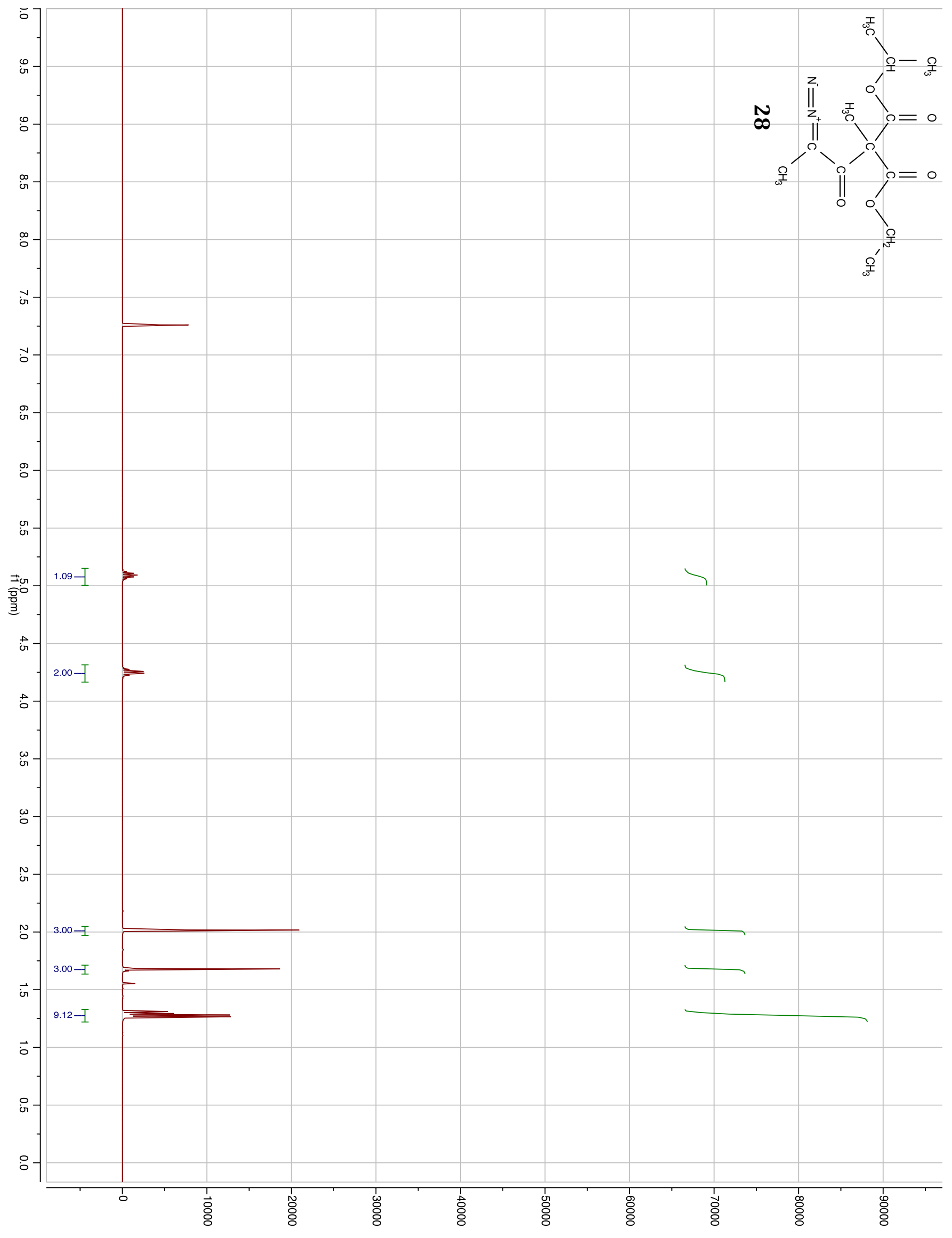




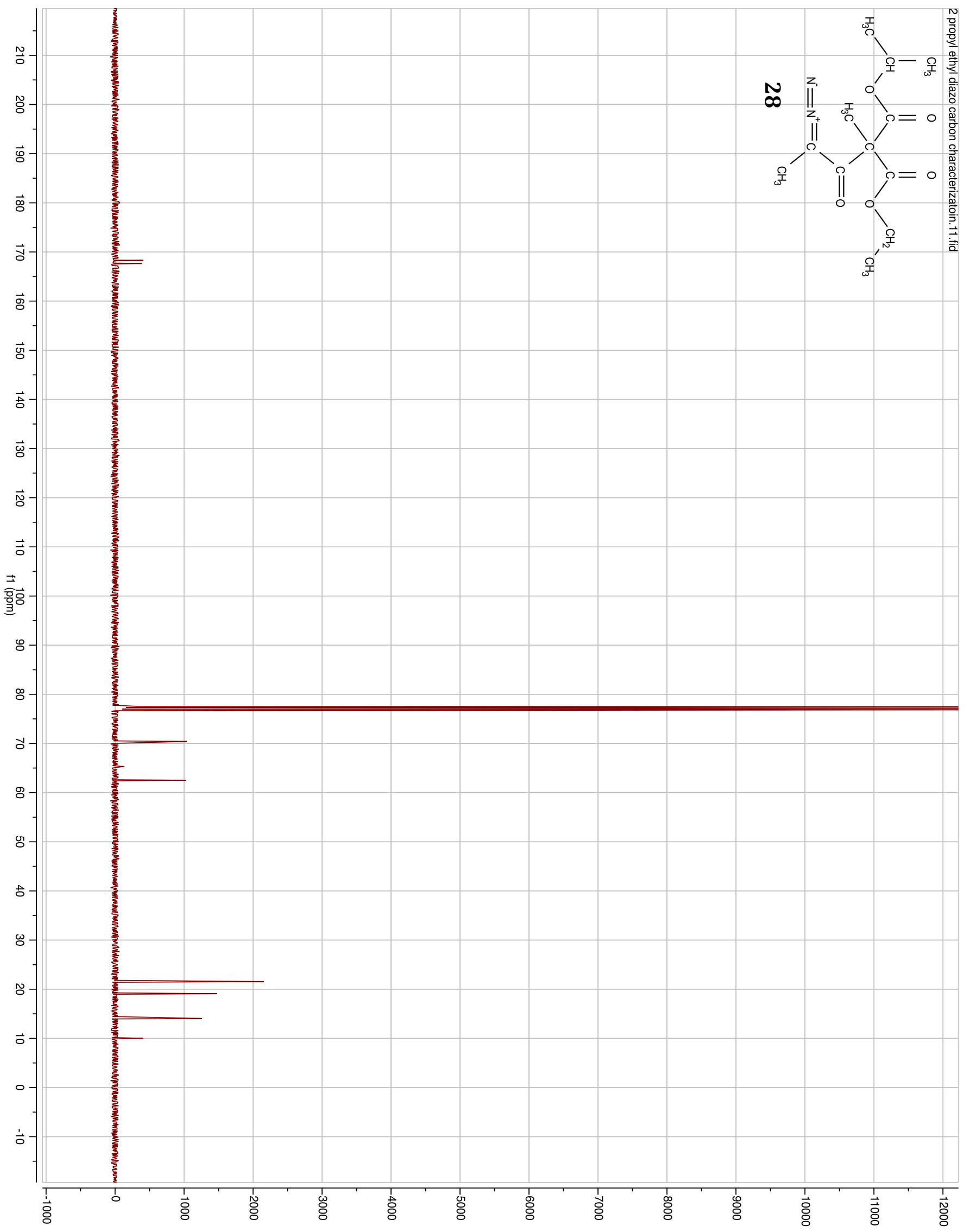




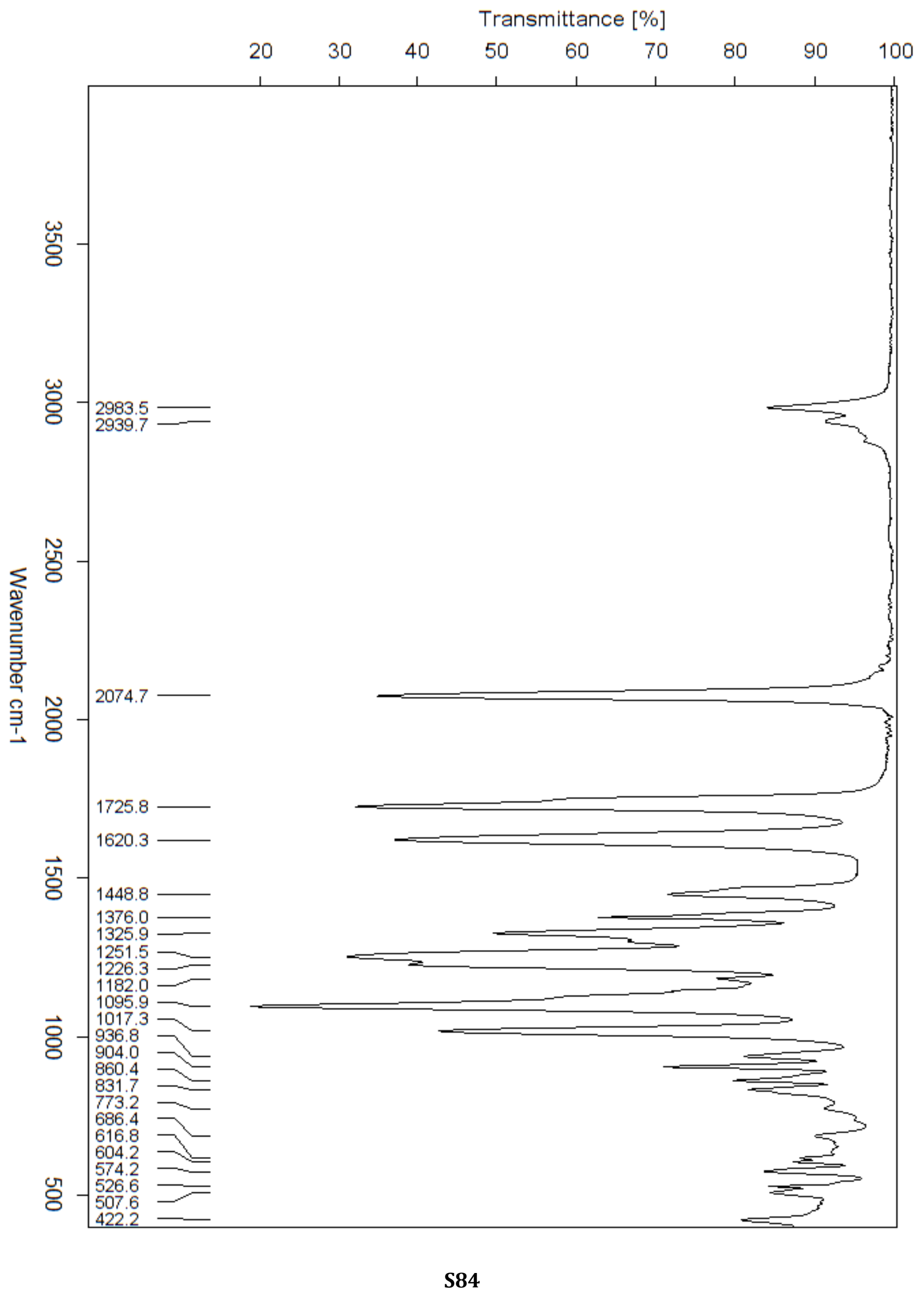




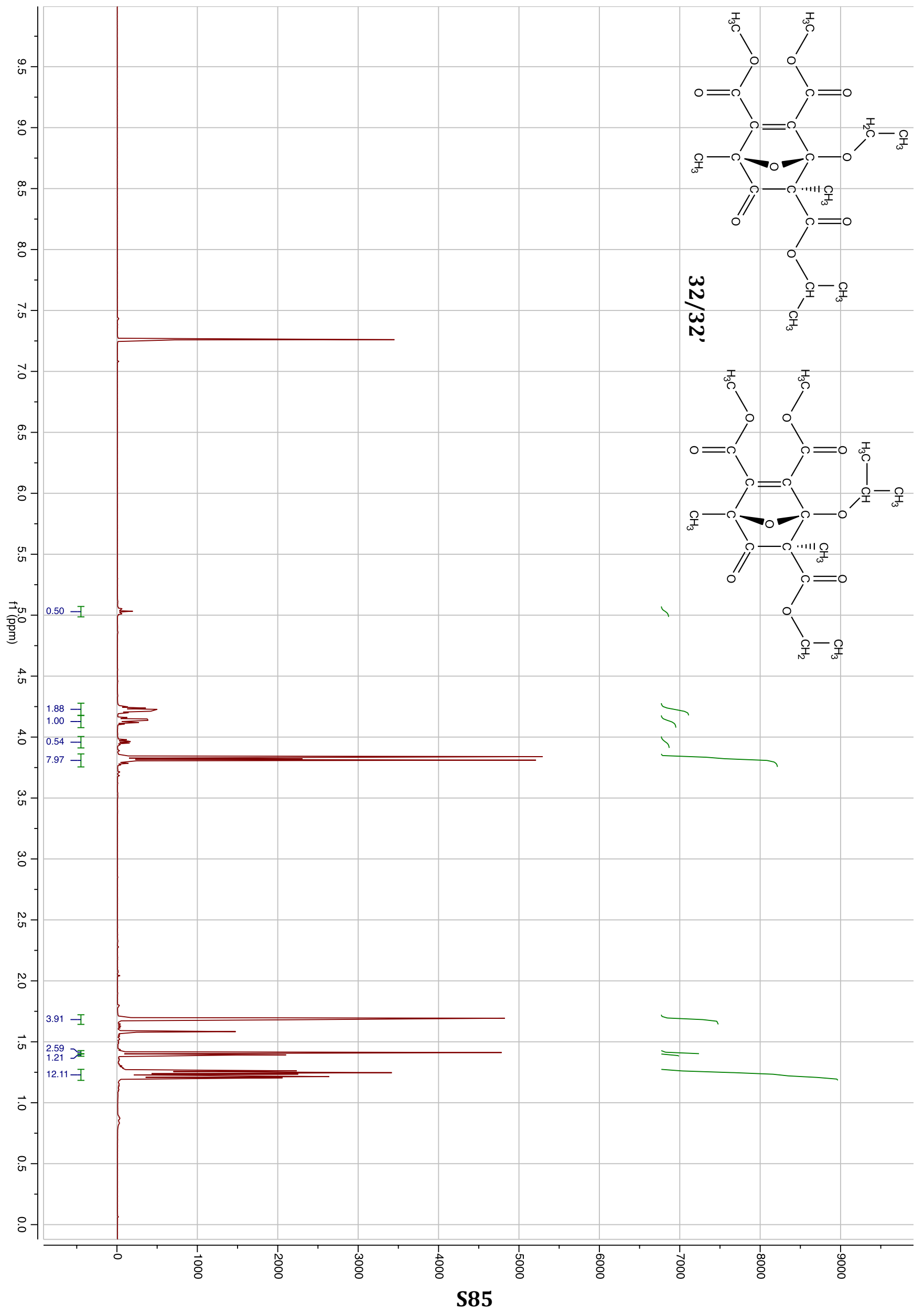




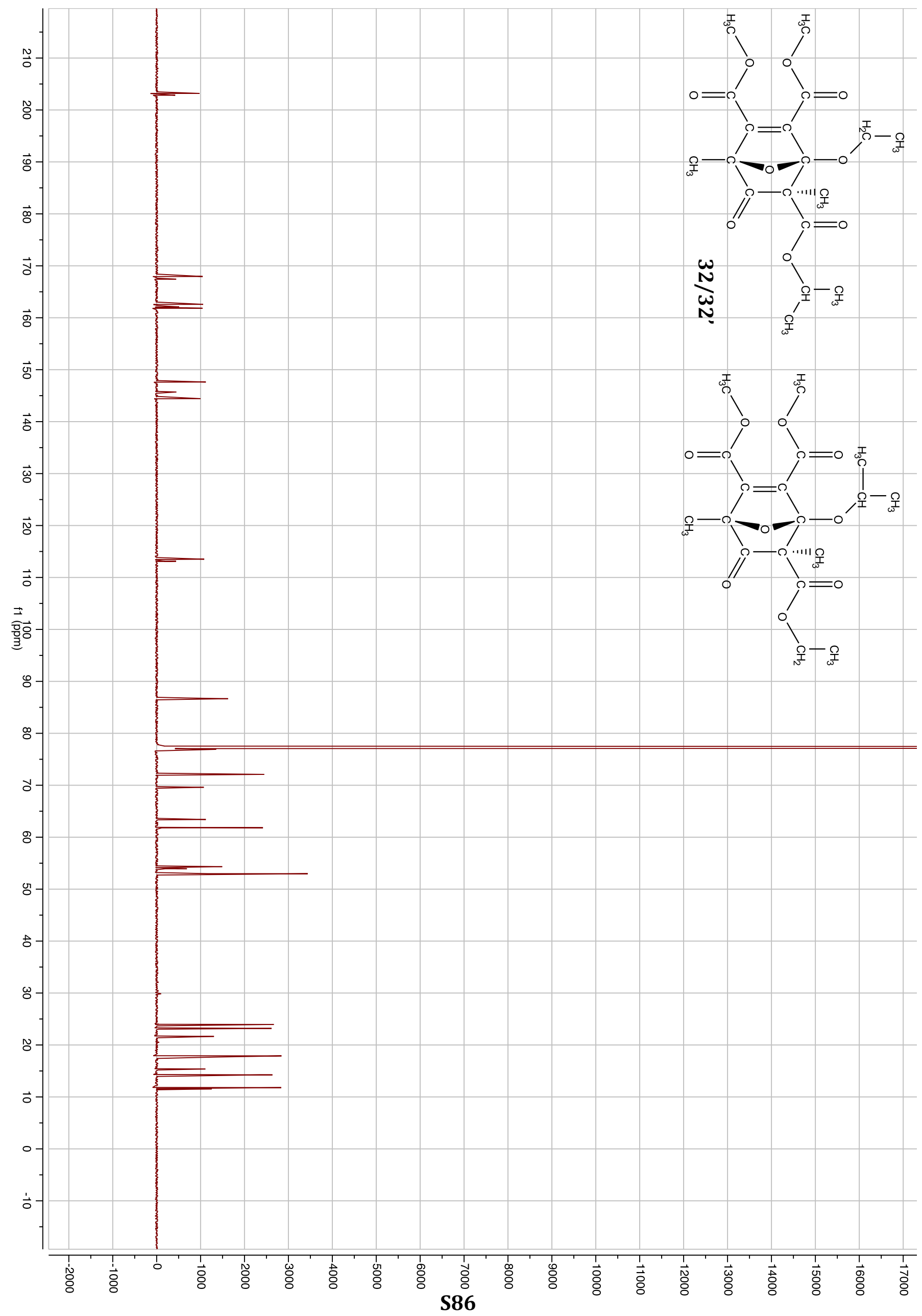




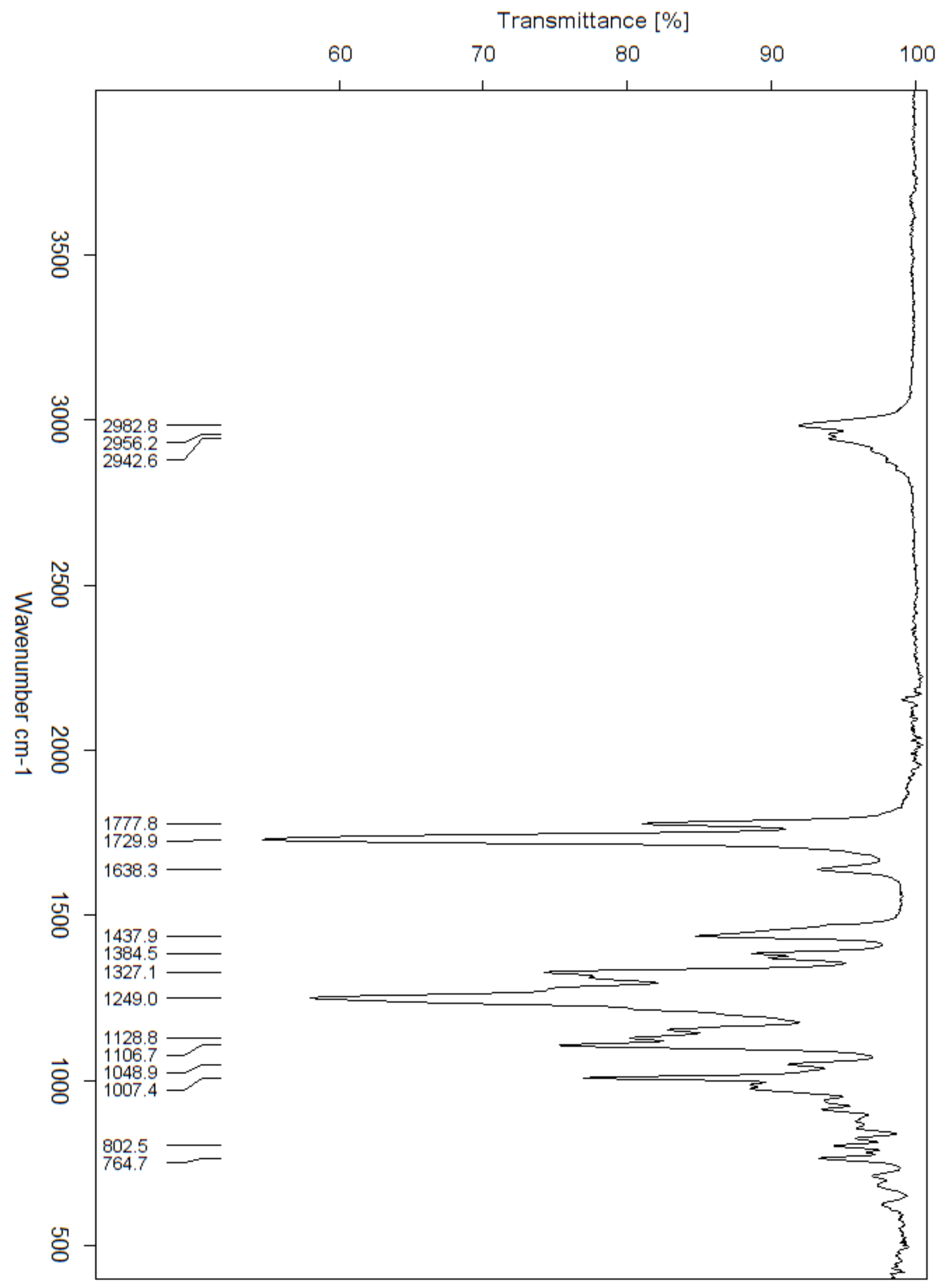



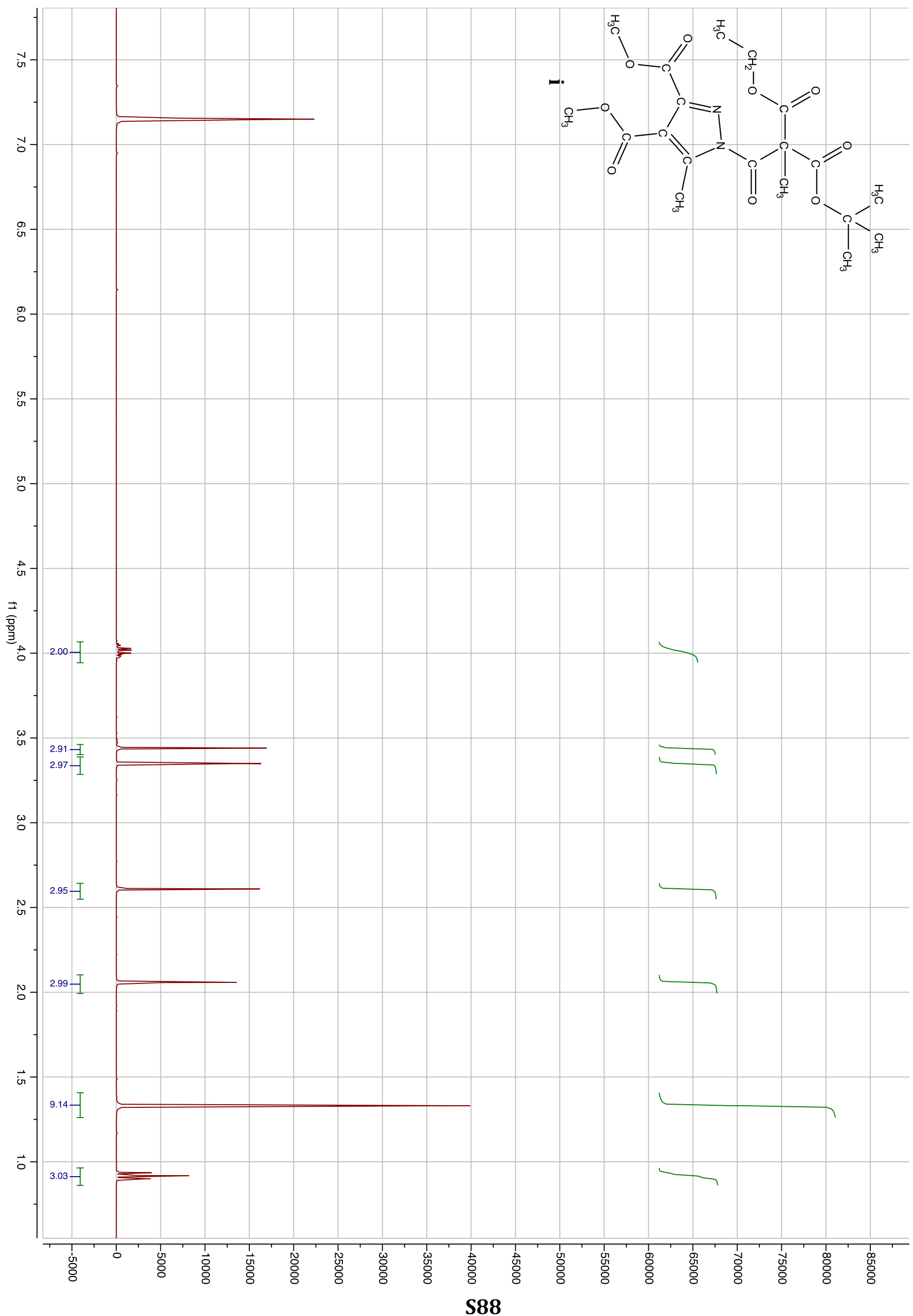


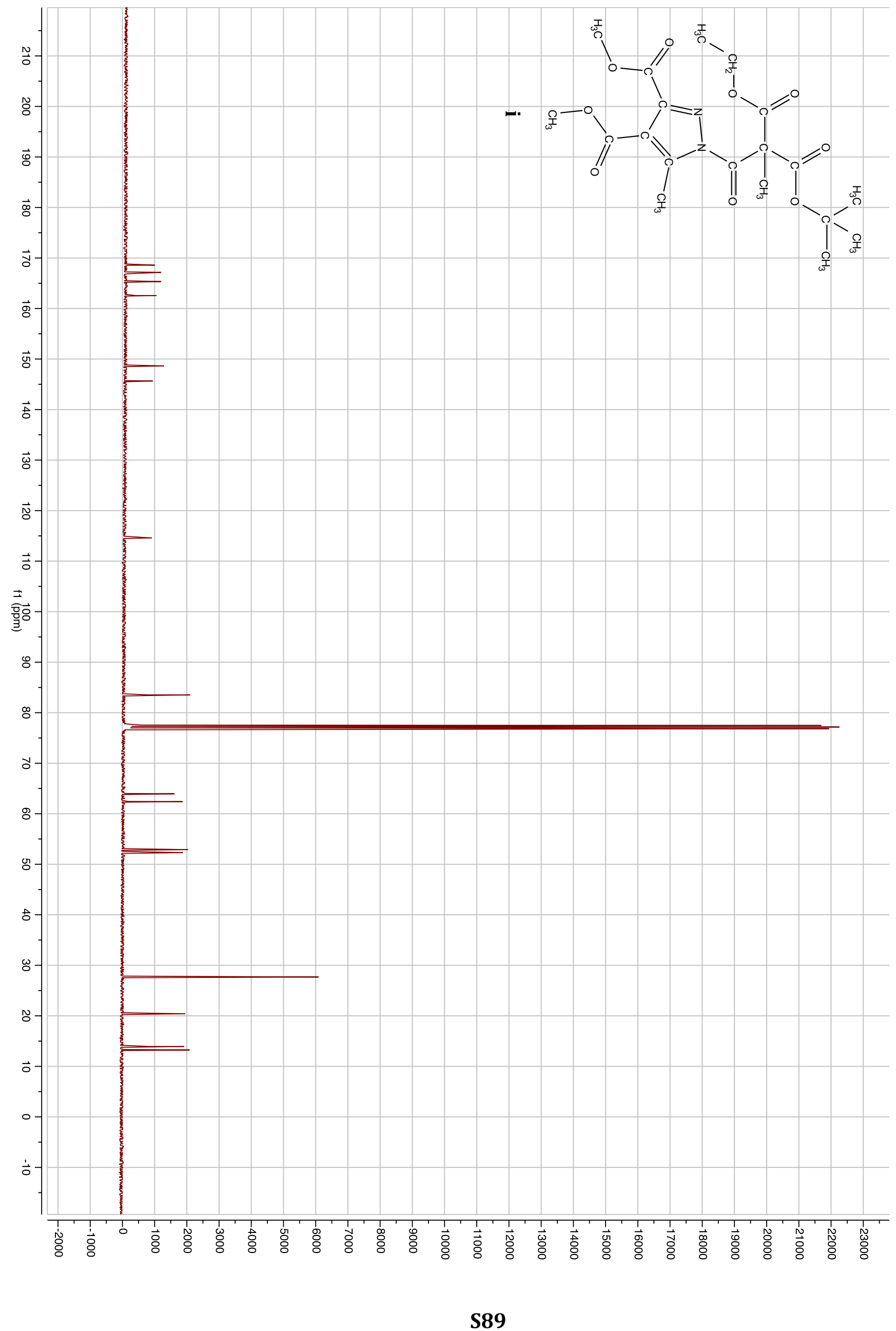




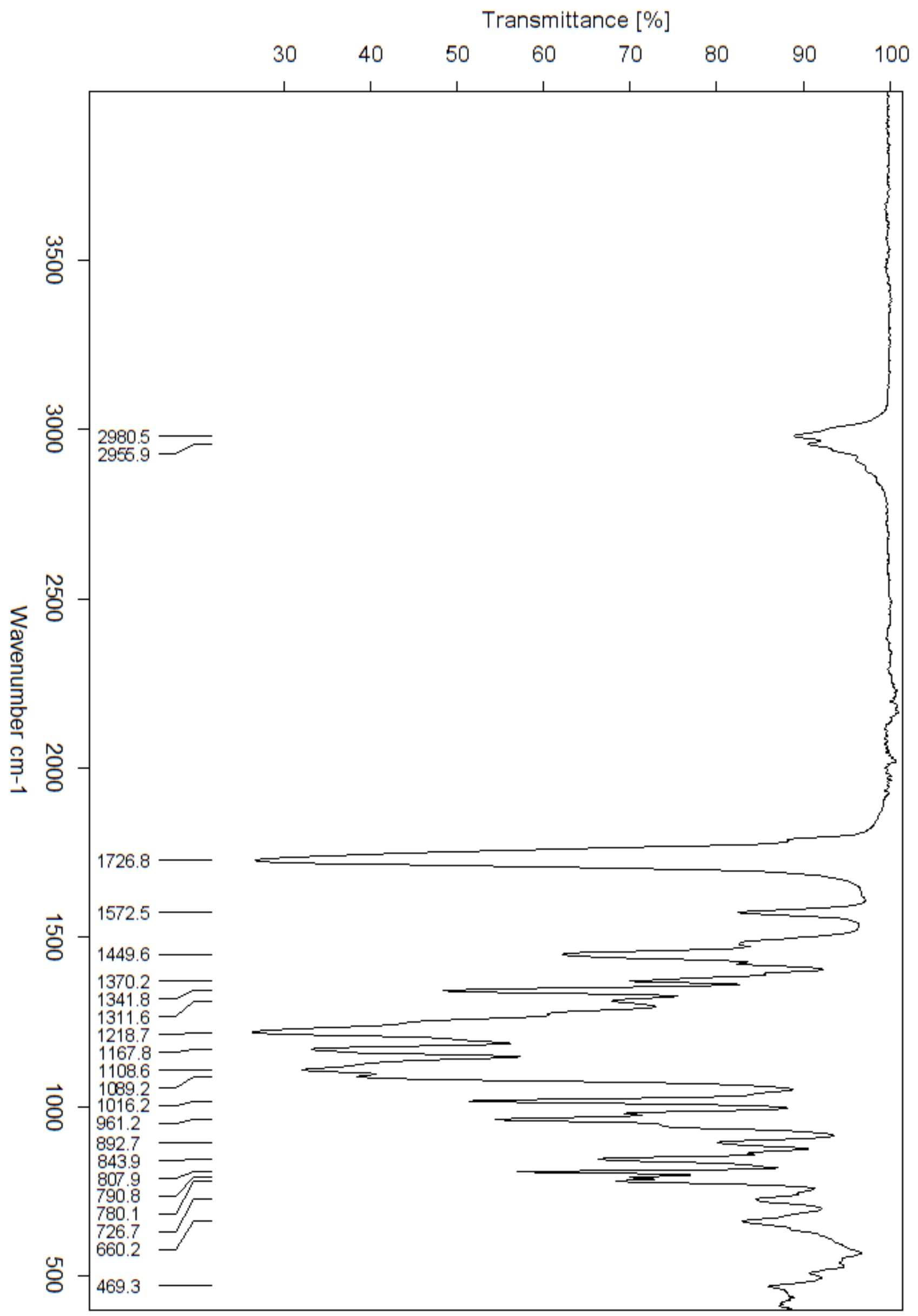




\section{References}

1) Sheldric, G., M. A short history of SHELX. Acta. Cryst. 2008, A64, 112

2) 1-(tert-butyl) 3-ethyl 2-methylmalonate (compound 21) Nahmany M.; Melman A. Org. Lett. 2001, 3, 3733.

3) di-tert-butyl 2-methylmalonate (compound 22) Qabaja G.; Wilent J.E.; Benavides A. R.; Bullard G. E.; Petersen K. S. Org. Lett. 2013, 15, 1266.

4) bis(2,2,2-trifluoroethyl) malonate) Mozhaev V. V.; Budde C. L.; Rich J. O.; Usyatinsky A. Y.; Michels P. C.; Khmelnitsky Y.L.; Clark D. S.; Dordick J. S.Tetrahedron 1998, 54, 3971.

5) 2-oxopropanoyl chloride Ottenheijm H. C. J.; Tijhuis M.W. Org. Synth. 1983, 61, 1

6) Lee, C.-W. The Formal Asymmetric Synthesis of (+)-Epoxysorbicillinol. Ph. D. Thesis, Yale University, New Haven, CT, 2005.

7) 1-ethyl 3-isopropyl 2-methylmalonate (compound 23) a) Shelkov R.; Nahmany M.; Melman A. J. Org. Chem. 2002, 67, 8975. b) Tural S. Turk J. Chem. 2008, 32, 169. (In this reference zinc perchlorate was used as a transesterification catalyst in a process that employed 2-propyl alcohol and diethyl methyl malonate.) 